\title{
Discovery Against the Defense: Tilting the Adversarial Balance
}

\author{
Robert P. Mosteller
}

TABLE OF CONTENTS

PAGE

I. The Scope of Developments .................... 1574

A. History of Procedural Discovery................... 1574

B. Impact of the Discovery "Revolution" in the States ..... 1579

C. Williams v. Florida ......................... 1585

II. Compulsion Under the Fifth Amendment.......... 1592

A. Compulsion in Its Pristine Form ................ 1593

B. The Second Compulsion Model-The Balancing of Interests .................................. 1595

III. The Fifth Amendment Applied to Prosecutorial Discovery................................... 1603

A. Hypothetical Case One: A Fully Usable Pretrial Discovery Deposition with Uncertainty Eliminated .......... 1605

1. Constitutionally Impermissible Burdens Are Imposed by the Operation of This Hypothetical Rule ........ 1606

2. The Insanity Defense-Application of Fifth Amendment Principles to Discovery That Incriminates .... 1612

B. Hypothetical Case Two: Typical Discovery Rules with Uncertainty Eliminated ......................... 1616

1. Testimonial Aspects of Discovery ............... 1617

2. Discovery of the Nature of the Defense ............ 1619

3. Discovery of Witness Names and Addresses ........ 1620

4. Discovery of Witness Statements .............. 1620

C. Hypothetical Case Three: Typical Discovery Requirements with Uncertainty Present .................. 1621

1. Impact of Procedural Issues: The Character of the Defendant's Response ........................ 1623

a. Defendant Provides Discovery............... 1623

b. Defendant Declines to Provide Discovery Under Claim of Self-Incrimination ................ 1625

$i$. Reasonable Fear of Incrimination: A Necessary and Sufficient Condition of a Valid Claim .............................. 1628 
ii. Use Immunity-An Adequate but Impractical Solution......................... 1632

D. Hypothetical Case Four: Discovery Deposition Limited to Impeachment ................................. 1635

1. The Impact of the Rule .................... 1637

2. State Interests in Impeachment ................ 1640

a. Impeachment as a Remedy to a Change in Defenses That Permits Inadequate State Investigation........................... 1640

b. Impeachment as a Remedy for Willful Deception .............................. 1641

c. Impeachment Justified Solely as a Relevant Prior Inconsistent Statement .................... 1643

3. Additional Issues Raised by Uses Beyond Impeachment ............................ 1646

4. State Use of Discovery Statements to Impeach the Defendant .............................. 1648

IV. The Collapse of Other Doctrines Protecting DEFENSE ConfIDENCES .......................... 1653

A. Disclosure of the Identity of Expert Witnesses and Their Reports................................... 1655

1. The Limited Scope of Fifth Amendment Protection . 1655

2. The Limited Scope of the Work Product Doctrine... 1657

3. The Effective Assistance of Counsel Guarantee of the Sixth Amendment............................ 1664

4. Waiver as a Conditional Concept............... 1672

B. Discovery of Statements Made by Witnesses to the Defense 1674

C. Prosecutorial Use of Defendant's Statements Within the Attorney-Client Privilege ....................... 1676 


\title{
Discovery Against the Defense: Tilting the Adversarial Balance
}

\author{
Robert P. Mosteller $†$
}

"Things fall apart; the centre cannot hold."

-William Butler Yeats, The Second Coming.

Beginning early in the 1970's, revolutionary expansion occurred in criminal discovery by the prosecution against the defense. Where the defendant previously enjoyed apparently permanent constitutional protection froin state incursions, extensive pretrial disclosures by the defendant are now routinely required. ${ }^{1}$ Discovery against the criminal defendant as a right of the prosecution, independent of any "triggering" request by the defendant for discovery, ${ }^{2}$ is both widespread-available in

$\dagger$ Associate Professor of Law, Duke University. B.A. 1970, University of North Carolina at Chapel Hill; J.D. 1975, Yale University; M.P.P. 1975, Harvard University. I would like to thank Katharine Bartlett, Donald Horowitz, Kenneth Pye, Thomas Rowe, Christopher Schroeder, and Peter Westen for their valuable comments on an earlier draft of this Article, and Bart Patterson, Robert Danforth, Joseph McHugh, Ellen Fishbein Mills, and Francis J. Mootz III for their assistance with the research. I would also like to thank the Duke Law School for providing assistance for my research by awarding me an Eugene T. Bost Research Professorship. I would particularly like to thank my colleague Sara Sun Beale for her insightful comments and careful criticism and for the generous gift of her time.

1. A number of commentators have noted some of these changes, but their scope has been largely ignored. One reason for this may be that these changes have occurred primarily in the states, where they are not easily mapped, rather than in the federal system, where most legal researchers concentrate their efforts. See, e.g., Allis, Limitations on Prosecutorial Discovery of the Defense Case in Federal Courts: The Shield of Confidentiality, 50 S. CAL. L. REv. 461 (1977); Feldman, The Work Product Rule in Criminal Practice and Procedure, 50 U. C1N. L. REv. 495, 496 n.8 (1981) ("Because most jurisdictions follow the federal work product version, this Article will focus on rule 16 and federal case law.").

In the federal system, discovery against the defendant remains very limited; the federal rules are not representative of rules in many states. Moreover, since the vast bulk of criminal prosecutions occur in the states, discovery in the federal system is of less significance.

2. I use the term independent to describe such discovery by the prosecution and conditional to describe discovery that is available to the prosecution only upon request for discovery by the defense. For example, the Federal Rules of Criminal Procedure permit discovery against the criminal defendant only when he "triggers" the prosecutor's right to discovery by requesting disclosure of certain types of information from the government. FED. R. CRIM. P. 16(b)(1). In this Article, I concentrate on those rules that grant independent discovery rights to the prosecution. For a discussion of the constitutionality of conditional discovery rules see infra note 141 .

Also, I do not attempt to discuss under what circumstances a "preclusion" sanction against the defense might be constitutional for violation of discovery rules. Compare Alicea v. Gagnon, 675 F.2d 913, 923 (7th Cir. 1982) (absent exceptional circumstances, fifth, sixth, and fourteenth amendments prohibit preclusion of defendant's testimony for violation of notice of alibi rule) with People v. Taylor, 491 N.E.2d 3, 6-7 (IIl. App. Ct. 1986) (trial court properly exercised discretion to exclude testimony of defense witnesses as sanction for violation of discovery rule), cert. granted, 107 
half the states-and wide-ranging in terms of the scope of information available through authorized disclosures. In several states, the prosecution may obtain:

1. A specification of all defenses that the defendant will raise;

2. The names and addresses of all witnesses that the defendant intends to call at trial; and

3. All statements of defense witnesses, including memoranda of unsigned oral statements.

In most of these states, neither the rules nor the case law explicitly prohibits the prosecutor from using the information so obtained in the state's case-in-chief. ${ }^{3}$ Two states even require the defense to create statements of defense witnesses for the purpose of discovery if the statements were not otherwise taken. Others require the defense to provide the prosecution with any statements obtained from government witnesses, whether or not the defense intends to use the statements for impeachment purposes. ${ }^{4}$

Discovery of unsuccessful efforts to prepare a defense, even when that defense will not be presented at trial, is also widely available. Developments here have chiefly concerned discovery of the defense's expert witness; his identity and any report he may have prepared are often ruled discoverable. If the expert's report does not involve a communication from the defendant to the expert, courts frequently find it unprotected by any constitutional right or other privilege. ${ }^{5}$ When the expert has obtained statements from the defendant, they are generally recognized as protected at least by attorney-client privilege. Many courts, however, hold the privilege waived if the defense introduces any other evidence relating to the examination. ${ }^{6}$ One court has further held that when the defendant testifies in his own behalf he waives all protections; thus, the defendant's statement obtained by the expert may be used to impeach his testimony. ${ }^{7}$

The steady erosion of traditional defense protections has been sped along in part by two major errors in legal analysis that have evolved into virtually unchallenged doctrines. Together, these developments largely

S. Ct. 947 (1987). Rather than focus on the permissible remedies for violation of rules that allow prosecutorial discovery, I will examine when such rules themselves are constitutional.

3. Indeed, the courts in at least two states have refused to limit prosecutorial use of discovered information to rebuttal of the defendant's case. State ex rel. Keller v. Criminal Court of Marion County, 262 Ind. 420, 426-29, 317 N.E.2d 433, 436-38 (1974) (discovery of defenses and defense witnesses is constitutional, even if incriminating, so long as diseovery is fairly balanced); Commonwealth v. Donovan, 610 S.W.2d 601, 601-02 (Ky. 1980) (discovery of names and addresses of witnesses whom the defense intends to call at trial for any defense constitutionally valid).

4. See infra note 42.

5. See infra note 282 and accompanying text.

6. See infra note 357 .

7. See infra notes $390-93$ and accompanying text. 
explain why many courts have remained oblivious to the constitutional objections to state discovery rules. First, the courts have all but written off the fifth amendment as providimg any restriction upon discovery of information that the defendant may ultimately want to introduce at trial. The principal source of this development is the Supreme Court's decision in Williams v. Florida, ${ }^{8}$ which upheld the constitutionality of Florida's notice of alibi rule. This decision has been interpreted as granting the states carte blanche to develop discovery rules that give the prosecutor an independent right to obtain even potentially incriminatimg inforınation free from the strictures of the fifth amendment.

Second, courts increasingly emphasize the concept of "litigative fairness" in deterinining the scope of constitutional as well as common law and statutory privileges. ${ }^{9}$ This development has produced further inroads into the privilege against self-incrimination and has also weakened the attoruey-chient privilege and the work product doctrine. The fifth amendment diminution in the wake of Williams left a void into which these other privileges could have expanded in order to shield the defendant from demands of prosecutorial discovery. Instead, these privileges have been weakened due to the courts' concern with enhancing the truth-seeking process and fear that these privileges may provide a shield for perjury by the defendant. As a result, court decisions have eroded the defendant's right to effective assistance of counsel.

The process of erosion has been incremental. Courts have examined each new intrusion into the defendant's privileges independently, alınost

8. 399 U.S. 78 (1970).

9. Concerns for fairness have helped shape the development of criminal discovery throughout its history. Initially the defense was perceived as possessing enormous advantages in criminal litigation. This perception fed the traditional reluctance to expand discovery for the defendant. See United States v. Garsson, 291 Fed. 646, 649 (S.D.N.Y. 1923); see also Louisell, Criminal Discovery: Dilemma Real or Apparent?, 49 CALIF. L. ReV. 56, 57 \& n.3 (1961).

This argument against discovery was countered by a series of articles denying the defense had any advantage over the prosecution in criminal litigation. See Goldstein, The State and the Accused: Balance of Advantage in Criminal Procedure, 69 YALE L.J. 1149, 1172-92 (1960); see also Brennan, The Criminal Prosecution: Sporting Event or Quest for Truth, 1963 WASH. U.L.Q. 279, 285-87 (1963); Moore, Criminal Discovery, 19 HASTINGS L.J. 865, 878-79 (1968). In fact, the state possesses resources and investigative tools vastly superior to those of even the wealthiest defendant. See Nakell, Criminal Discovery for the Defense and the Prosecution-The Developing Constitutional Considerations, 50 N.C.L. REv. 437, 439-42 (1972). In addition, those favoring broadened discovery for the defense argued that the fundamental goal of the trial process-to determine the validity of the charges-required the granting of a measure of discovery irrespective of the relative advantages of the two parties. See, e.g., People v. Riser, 47 Cal. 2d 566, 586, 305 P.2d 1, 13 (1956), cert. denied, 353 U.S. 930 (1957); State v. Tune, 13 N.J. 203, 228-29, 98 A.2d 881, 894-95 (1953) (Brennan, J., dissenting), cert. denied, 349 U.S. 907 (1960); see also Pye, The Defendant's Case for More Liberal Discovery, 33 F.R.D. 42, 83 (1963).

Those favoring expanded discovery for the defense carried the day and "liberalized" criminal discovery available to it. Opponents believed, however, that the appropriate balance between the prosecution and the defense had been distorted in the defense's favor. As a result, pressures to redress that perceived imbalance grew. 
in isolation, and have approved each in part because it had but a limited impact upon the total range of protections available to the defendant. The cumulative effect, however, has been profound. Through a series of small steps, each arguably justified, the traditional balance between the prosecution and the defense has been fundamentally altered. ${ }^{10}$ In some jurisdictions granting expansive discovery, the defendant retains full protection under the privilege against self-incrimination and his right to effective assistance of counsel only when he remains truly silent at trial and when his lawyer's case preparation generates no information potentially helpful to the government.

My thesis is that the fifth and sixth amendments require more protections for the criminal defendant. My position is a fundamentally conservative one; such protections are necessary to preserve the essential elements of our adversary system. Indeed, that the modest restraints on current practices set out below even need to be proposed shows just how intrusive prosecutorial discovery has become. Though not all discovery against the defense is unconstitutional, basic constitutional principles require the following limits on discovery against the defense:

1. The defendant may not be required under discovery rules to make statements that the prosecution may use directly or derivatively in its case-in-chief.

2. The defendant's statements required by discovery rules may not be used to impeach his trial testimony, except when the discovery statement was willfully false or materially impeded adequate prosecutorial preparation.

3. Unfavorable expert opinions produced by the defense during efforts to prepare a defense may not be discovered unless the defense will use sonie part of the expert's opimion.

4. Confidential communications by the defendant to his counsel may not be discovered. Discovery of the defendant's statements to his lawyer's agents is allowed only when either the defense affirmatively uses those statements at trial or the prosecution demonstrates a truly compelling need for the expertise of that particular agent. "Compelling need" would not be shown by a general state interest in improving the accuracy of the trial process by impeaching a defendant with his prior inconsistent statements.

Some of these linitations flow froin the fifth amendinent, which, properly construed, prohibits at least discovery of testimonial evidence

10. At least in this area, the warning of Boyd v. United States, 116 U.S. 616, 635 (1886), has proven correct:

It may be that it is the obnoxious thing in its mildest and least repulsive form; but illegitimate and unconstitutional practices get their first footing in that way, namely, by silent approaches and slight deviations from legal modes of procedure .... A close and literal construction deprives [constitutional provisions for the security of persons and property] of half their efficacy and leads to gradual depreciation of the right, as if it consisted more in sound than in substance. 
the state may use to establisl its case-in-chief. Often discovery rules, sucl as the notice of alibi rule at issue in Williams, will not raise substantial self-incrinination issues. Acknowledging the fact that many discovery rules are valid under the fifth amendment, however, is a far cry from declaring, as soine courts liave, that the privilege against self-incrinination is irrelevant. ${ }^{11}$ When the possibility of incrimination from required disclosures is apparent, discovery, which the state may use to establish guilt, violates this privilege. ${ }^{12}$ Indeed, protection against such use lies near the lieart of the historical origins of the privilege against compulsory self-incrimination. ${ }^{13}$

Other constitutional limitations derive from the sixth amendment riglit to effective assistance of counsel. This right is fundamentally im conflict witli a systein that requires counsel to provide the government with the product of his efforts when they prove damaging to the defense. The defendant would be protected against sucli requirements if states interpreted concepts of waiver of existing common law and statutory privileges more restrictively and, I submit, inore accurately. The confidentiality of the defense counsel's efforts in developing a vigorous defense, lowever, cannot and slould not depend exclusively upon a state's definition of such protections. Our adversary system and its constitutional foundations require more. Unless we are only cymically guaranteeing a riglit to effective assistance of counsel, the sixtli amendment inust protect counsel's ability to investigate and prepare a defense without the fear that any misstep may lielp convict the defendant. ${ }^{14}$

Part I of this Article examines the history of prosecutorial discovery and describes the extent of sucli discovery presently allowed in the states. Because the revolutionary expansion of prosecutorial discovery was prompted in large part by the Supreme Court's decision in Williams $v$. Florida, I analyze that decision and show that it left unanswered most of the critical constitutional issues raised by the use of independent prosecutorial discovery.

Viewing the fiftl ainendment as the primary source of protection for the criminal defendant, I devote the bulk of my analysis to the implications of the privilege against self-incrimination for discovery against that defendant. Thus, in Parts II and III, I examine fiftlı amendment issues

11. See supra note 3 .

12. I further argue that the defendant must also be allowed to demonstrate a likelihood of incrimination from the required disclosure when the substantiality of the threat of incrimination is not suggested directly by the nature of the defense. See infra note 195.

13. See infra note $89-92$.

14. Some of these results are also required by the due process clause, but it has little independent significance. Where the due process clause would forbid discovery, the privilege against self-incrimination or the sixth amendment right to effective assistance of counsel will even more clearly require the same result. See infra note 144. 
raised by typical state discovery practices. I demonstrate that though Williams might be read as virtually nullifying the fifth amendment as a shield against prosecutorial discovery, the Supreme Court's analysis of the compulsion issue in other cases belies that result. In Part II, I examme the models of compulsion with which the Court tests the constitutionality of practices that penalize the exercise of fifth amendment rights. I demonstrate that in addition to proscribing compulsory selfincrimination in its pristime form, the fiftl amendment prohibits a range of practices that unjustifiably penalize the defendant for asserting his fifth amendinent rights. In Part III, I test the limits of the Williams holding by applying these inodels of coinpulsion to several hypothetical discovery rules. I conclude that, though the precise discovery rule at issue in Williams will rarely create serious constitutional problems, other rules may violate the privilege against compulsory self-incrimination by placing too heavy a penalty on the defendant's decision to remain silent prior to trial.

Following this treatinent of the fifth ainendinent, I analyze the role of the attorney-client privilege, the work product doctrine, and the sixth ainendment in discovery against the criminal defendant. Part IV exainines the way in which prosecutorial discovery has reshaped and limited the work product doctrine and the attorney-client privilege. I conclude that in inportant respects, prosecutorial discovery violates the defendant's constitutional right to effective assistance of counsel and conflicts with the poticies supporting the work product doctrine.

The SCOPE OF Developments

\section{A. History of Procedural Discovery}

Discovery by the prosecution against the defense appeared first in the form of notice of alibi rules. ${ }^{15}$ Such rules typically require the defendant to give notice of his intention to rely on an alibi defense and provide specific information on his location at the time of the crime and the name and address of any witness who will support the defense. ${ }^{16}$ The

15. See Note, Federal Criminal Procedure-Proposed Rules on Notice of Alibi, Deposition, and Pre-Trial Conference, 39 Notre Dame LAw. 35, 35 (1963).

16. Between 1927 and 1942, 14 states adopted some form of notice of alibi rule. These states were: Arizona, Indiana, Iowa, Kansas, Michigan, Minnesota, New Jersey, New York, Ohio, Oklahoma, South Dakota, Utah, Vermont, and Wisconsin. Epstein, Advance Notice of Alibi, $55 \mathrm{~J}$. CRIM. L. \& CRIMinology 29, 30 n.16 (1964); Louisell, supra note 9, at 61 n.13; Note, supra note 15, at 35 n.8. See also Williams v. Florida, 399 U.S. 78, 82 n.11 (1970) (listing the fifteen states in addition to Florida that in 1970 had notice of alibi rules).

One goal of these enactments was the redress of the perceived advantage of the defense in criminal procedure; another was the closely related desire to deter perjury. See generally Dean, Advance Specification of Defense in Criminal Cases, 20 A.B.A. J. 435, 435-37 (1934); Millar, The Modernization of Criminal Procedure, 11 J. CRIM. L. \& CRIMINologY 344, 350 (1920). Citing anecdotal information from states, several articles applauded the success of notice of alibi rules in 
major arguments in favor of such rules are: (1) prevention of surprise by the defense through the last-minute production of this classic "hip pocket" defense; (2) deterrence of perjured alibi testimony; and (3) reduction of mid-trial delays, which would otherwise be required for the prosecution to investigate the surprise alibi. ${ }^{17}$

Prosecutorial discovery expanded into new areas in 1962 when the California Supreme Court decided Jones v. Superior Court. ${ }^{18}$ Jones is a landmark case in the development of prosecutorial discovery, and its rationale, which apphes beyond the special circumstances of the alibi defense, supported the development of broader and more specialized discovery against the defense.

Jones was charged with rape. On the day set for trial he requested a

reducing the frequency of alibis and increasing the percentage of convictions. Esch, Ohio's New "Alibi Defense" Statute, 9 THE Panez 42, $42-43$ (1931); Toy, Michigan Law on Alibi and Insanity Defenses Reduces Perjury, 9 THE Panel 52, 52 (1931).

Between 1942 and 1970, only two states, Florida and Pennsylvania, added notice of alibi rules. Why the spread of such rules slowed so markedly is somewhat speculative. One cause may have been the substantial questions raised by commentators concerning the fairness and constitutionality of such rules. Cf. Advisory Committee Note to Rule 12.1, 62 F.R.D. 271, 293; Everett, Discovery in Criminal Cases-In Search of a Standard, 1964 DukE L.J. 477, 497-99 (1964). Also, some prosecutors found notice of alibi rules relatively unhelpful. See Note, supra note 15 , at $38 \mathrm{nn} .32-35$.

The federal courts had no notice of alibi rule during this period. In 1943 and 1944, the Advisory Committee on the Federal Criminal Rules proposed a notice of alibi rule for the federal courts. The Committee, however, was strongly divided over whether there should be such a rule at all and, if so, how it should be structured. Advisory Committee Note to Rule 12.1, 62 F.R.D. at 293; Orfield, The Preliminary Draft of the Federal Rules of Criminal Procedure, 22 TEx. L. REv. 37, 57 (1943). The Committee submitted two formulations, but both were rejected by the Supreme Court. In 1962, the Advisory Committee again drafted an alibi notice rule, but it was withdrawn before submission to the Standing Committee on Rules of Practice and Procedure. Advisory Committee Note to Rule 12.1, 62 F.R.D. at 293; Wright, Proposed Changes in Federal Civil, Criminal, and Appellate Procedure, 35 F.R.D. 317, 326 (1964); see also Note, supra note 15, at 36 n.11.

17. Epstein, supra note 16, at 31-32. Epstein provides additional justifications for the notice of alibi rule. First, he contends that the alibi notice rule will save trial time because the prosecutor will choose to dismiss some cases once the alibi witness has been interviewed and "the district attorney is satisfied that the alibi is true." Id. at 32. The author made this argument in the face of his own survey data strongly undercutting that rationale. $I d$. at $32 \&$ n. 37 . In his dissent in Williams v. Florida, 399 U.S. 78, 106-16 (1970), Justice Black effectively refuted that argument: a defendant will rarely need a rule to require disclosure that will likely result in a dismissal. Rather, "the only time the State needs the compulsion provided by this procedure is when the defendant has decided that such disclosure is likely to hurt his case." Id. at 111.

Epstein also argued that discovery against the defense is a prerequisite to liberal discovery: "Neither prosecutors nor trial judges will agree to criminal discovery unless it is a two-way street." Epstein, supra note 16, at 29. This is indeed a very important strategic concern for those who support broader defense discovery, see infra notes $22 \& 26$, but does not speak to the validity of the rule.

Epstein's article is probably most remarkable for its profound influence despite its rather superficial analysis. For instance, he does not address the argument that while alibis are easily fabricated, effective alibis, which involve independent corroboration or support by neutral witnesses, F. Bailey \& H. Rothblatt, Investigation and Preparation of Criminal Cases $\$ 7.9$ (2d ed. 1985), are little easier to manufacture than other defenses.

18. 58 Cal. 2d 56, 372 P.2d 919, 22 Cal. Rptr. 879 (1962). 
continuance, asserting that he was impotent and needed additional time to gather medical evidence pertaining to injuries, suffered several years before, which allegedly caused that condition. The trial court granted the continuance, and several days later the prosecution inoved for discovery of the names and addresses of medical experts subpoenaed by the defendant to testify concerning his prior injuries and present impotence, the names and addresses of physicians who had treated hin, and reports and $x$-rays bearing on prior injuries and present impotence. The trial court granted the state's discovery motion. Jones sought a writ of prohibition to block enforcement of the trial court's order. ${ }^{19}$

Writing for the court, Justice Traynor noted that in expanding the discovery available to the defendant, the California courts had not been following a constitutionally mandated course but rather had been seeking "to proinote the orderly ascertainment of the truth. That procedure should not be a one-way street." ${ }^{20}$ The court held that while the state constitution's privilege against self-incrimination and the attorney-client privilege barred discovery of those documents and witnesses that the defendant did not intend to use at trial, discovery of witnesses and documents that the defendant did intend to use did not violate these privileges.

Adopting a concept proposed soine two decades before to validate the notice of alibi rule, Traynor found no constitutional infirnity in accelerating the timing of the disclosure of an "affirnative" defense $\mathrm{e}^{21}$ such as impotence:

[T] he alibi statutes do not infringe on the privilege against self-incrimination. Rather they set up a wholly reasonable rule of pleading which in no manner compels a defendant to give any evidence other than that which he will voluntarily and without compulsion give at trial. Such statutes do not violate the right of a defendant to be forever silent. Rather they say

19. Id. at $57-58,372 \mathrm{P} .2 \mathrm{~d}$ at $920,22 \mathrm{Cal}$. Rptr. at 880 .

20. Id. at 60,372 P.2d at 921,22 Cal. Rptr. at 881 .

21. In dissent, Justice Peters argued that, even if limited to affirmative defenses, requiring the defense to reveal the nature and substance of its defense would violate the privilege against selfincrimination. The privilege, he argued, entitles the defendant to remain entirely silent until after the government establishes a prima facie case against him. Id. at 63-65, 372 P.2d at 923-24, 22 Cal. Rptr. at 883-84.

Justice Peters assumed that the majority found the disclosures constitutional for affirmative defenses because there "the sought after material will not or perhaps cannot be used by the prosecution in establishing its prima facie case but only to rebut this possible affirmative defense." 58 Cal. 2d at 65-66, 372 P.2d at 925, $22 \mathrm{Cal}$. Rptr. at 885. Hc assailed the majority's reasoning on both theoretical and practical grounds. At the theoretical level, Peters argued that any defense revelation prior to the government establishing its case might harm the defense-even informing the government that the defense is weak is, in itself, an incriminating admission. At the practical level, he believed it impossible for courts to determine what information the state could use only to rebut an affirmative defense rather than to prove its case against the defendant. Id. at 66,372 P.2d at 925 , 22 Cal. Rptr. at 885 . 
to the accused: If you don't intend to remain silent, if you expect to offer an alibi defense, then advance notice and whereabouts must be forthcoming; but if you personally and your potential witnesses elect to remain silent throughout the trial, we have no desire to break that silence by any requirement of this statute. ${ }^{22}$

Eight years after Jones, two events occurred which were critical to expansion of discovery against the defense. In June of 1970, the United States Supreme Court upheld the constitutionality of Florida's notice of alibi rule in Williams v. Florida. ${ }^{23}$ The Court held, without apparent limitation, that conditioning the right to present certain defenses at trial on pretrial disclosures does not violate the Constitution because such disclosures are not "compelled" within the ineaning of the fifth amendment. I will discuss the Williams opinion in detail below; ${ }^{24}$ for now, it is enough to note that many states viewed Williams as an invitation to expand prosecutorial discovery agamst crimmal defendants-free from the himitations of the Constitution. ${ }^{25}$

Two months later the American Bar Association, reading Williams very broadly, approved far-reaching discovery provisions as part of its Standards Relating to Discovery and Procedure Before Trial. ${ }^{26}$ These

22. $58 \mathrm{Cal} .2 \mathrm{~d}$ at $61-62,372$ P.2d at 922,22 Cal. Rptr. at 882 (quoting Dean, supra note 16 , at 440).

Professor Louisell concluded that for Justice Traynor "the viability of criminal discovery [was] more important and valuable than avoidance of a relatively slight additional encroachment on the principle against self-incrimination ...." Louisell, Criminal Discovery and Self-Incrimination: Roger Traynor Confronts the Dilemma, 53 CALIF. L. REV. 89, 99 (1965). Justice Traynor had been a critical actor in advancing hiberal discovery for the defendant in California, and both Traynor and Louisell believed that defense discovery could not continue to expand without some reciprocal prosecutorial discovery. Id. at $99 \&$ n.37; see also Traynor, Ground Lost and Found in Criminal Discovery, 39 N.Y.U. L. REv. 228, 246 (1964). Justice Traynor also believed that, with liberal discovery in favor of the defense as a prerequisite to prosecutorial discovery, it was fair to require the defendant to announce his defense prior to trial. Id. at 248-49.

23. 399 U.S. 78 (1970).

24. See infra text accompanying notes 57-83.

25. Indeed, in Wardius v. Oregon, 412 U.S. 470,474 (1973), the Supreme Court described the opinion almost in those terms:

The growth of such discovery devices [such as notice of alibi provisions] is a salutary development which, by increasing the evidence available to both parties, enhances the fairness of the adversary system. As we recognized in Williams, nothing in the Due Process Clause precludes States from experimenting with systems of broad discovery designed to achieve these goals.

Specifically, in addition to other causes, the Williams decision helped rekindle the expansion of the notice of alibi rule. In the 18 ycars between 1942 and 1970, only two states had adopted such rules. See supra note 16. In the next 14 years, 25 others did so. Note, Alibi Notice Rules: The Preclusion Sanction as Procedural Default, 51 U. CHI. L. REv. 254, 254, 281-85 (1984).

26. While even prior to the Williams decision substantial prosecutorial discovery was in the offing, that opinion had a clear and powerful impact upon the formulation of the American Bar Association standards relating to discovery. STANDARDS RELATING TO DISCOVERY AND Procedure Before Trial $\S 3.3$ (1969 \& Supp. 1970) [hereinafter 1969-70 ABA Standards]. Section 3.3, which had not existed in the proposed standards, was adopted after the Williams decision. It permits discovery of the names and addresses of defense witnesses. See id. $\S 3.3$ 
Standards, inter alia, authorize the court to require that the defense, upon request by the prosecution, provide notice of any defense intended to be used at trial and the names and addresses of all supporting witnesses. They permit the court upon the prosecutor's request to require the defendant to provide the results of scientific examinations "[s]ubject to constitutional limitations."27

The Standards also define a work product "privilege" for the prosecution but set out no similar protection for the defense. ${ }^{28}$ Work product is defined narrowly to include only the "opinions, theories, or conclusions" of the "prosecuting attorney or members of his legal staff."29 The commentary makes clear that the privilege is limited to the lawyer's analytical thought processes, not facts, ${ }^{30}$ and to the prosecuting attorney or those performing legal duties for her. ${ }^{31}$

Many states used these Standards as a blueprint for enactinent of the expansive discovery systeins that rapidly followed. ${ }^{32}$ The scope of these

Commentary at 3, 4-5 (citing Williams and quoting its language); see also Norton, Criminal Discovery: Experience Under the American Bar Association Standards, 11 LoY. U. CHI. L.J. 661,665 n.14, 704 (1980).

27. 1969-70 ABA STANDARDS $\S \S 3.2,3.3$.

28. See 1969-70 ABA STANDARDS $\S 2.6($ a)

The failure to provide work product protection for the defense may have occurred because defense disclosures were anticipated to be far less extensive than those required of the prosecution before the last-minute modifications to the Standards. See Norton, supra note 26, at 695-96. Professor Norton finds no evidence of an intention to give the defense counsel less protection than the prosecution. He ascribes the difference in treatment to the fact that defense disclosures were seen as unlikely to raise substantial work product issues. See also infra note 287.

Perhaps because of the haste with which prosecutorial discovery was expanded, another provision which may have merited revision was left unchanged. Standard 2.1(a)(i) requires the prosecutor to provide the names and addresses and written statements of witnesses she intends to call. The commentary explains that this provision is not intended to include "rebuttal witnesses" whom the prosecutor "holds in readiness to rebut evidence which he anticipates the accused will present" as opposed to witnesses who would be presented as part of the state's case-in-chief. 1969-70 ABA STANDARDS $\$ 2.1$ Commentary at 58. Whether the ABA intended to restrict "reciprocal duties requiring state disclosure to the defendant," which the Court in Williams had found important in sustaining Florida's notice of alibi rule against a due proeess challenge, is unclear.

29. 1969-70 ABA STANDARDS $\$ 2.6(a)$.

Since defense work product is not covered, the Standards, understandably, addressed neither whether such a narrow definition of work product as applied to the defense would be appropriate nor whether it might raise any constitutional issues under either the fifth amendment or the sixth amendment's right to counsel.

30. [T] he report of an attorney as to what he had heard, seen or otherwise perceived with his senses or implements would not be protected from diselosure .... Merely because the investigator is a lawyer ... does not throw the work product mantle around his investigation of the facts. If a lawyer investigating the case finds an article of clothing, or takes a statement from a witness, such items must be disclosed . . . .

1969-70 ABA STANDARDS $§ 2.6$ Commentary at 90-91.

31. Since material and information are work product only to the extent that they reflect the mental processes of the prosecuting attorney and his legal staff, the opinions, theories and conclusions of lab technicians or other experts would remain discoverable.

1969-70 ABA STANDARDs $\$ 2.6$ Commentary at 91 .

32. The 1969-70 ABA Standards also influenced the Advisory Committee on the Federal 
developments is detailed below. ${ }^{33}$

\section{B. Impact of the Discovery "Revolution" in the States}

Discovery against the criminal defendant expanded tremendously in many states beginning in the 1970's. Currently, in addition to prosecutorial discovery of the specific defenses of alibi and insamity, available in the great majority of states, twenty-five states grant the prosecution an independent right to receive discovery from the defense of at least one of the following: defenses, witness names, statements of witnesses, reports of experts, or documents and tangible evidence. ${ }^{34}$ Another seven states provide for very broad disclosure from the defendant,

Criminal Rules, which proposed similar provisions. See Proposed Amendments to Criminal Rules, 48 F.R.D. 553, 587-95 (providing extensive independent discovery rights to the prosecution under Rule 16). The Supreme Court approved such independent discovery in 1974, see 62 F.R.D. 271, 304-07, but Congress revised Rule 16 before adoption and made all prosecutorial discovery conditional upon a defense request for discovery. See supra note 2 . Although not adopted, the proposed federal rules influenced the formulation of discovery rules in a number of states. See, e.g., N.M. DisT. CT. R. Crim. P. commentary to Rule 28 at 67; VT. R. CRIM. P. commentary to Rule 16.1 at 101.

33. While the growth of prosecutorial discovery has been frequently noted, see, e.g., Blumenson, Constitutional Limitations on Prosecutorial Discovery, 18 HARv. C.R.-C.L. L. REv. 123, $123 \mathrm{n} .1$ (1983), its remarkable scope has not been documented. I set the developments out in detail in the following pages to demonstrate the extent of these changes and their importance to the nature of criminal litigation in many states. Readers who are familiar with these developments may proceed infra to Section $\mathrm{C}$ of this Part.

34. Six states allow independent prosecutorial discovery in all five categories: Arizona, Hawaii, Mllinois, Minnesota, Montana, and Washington. Another four states provide independent discovery in four categories: Massachusetts (defenses are independent, but documents, expert reports, and statements of witnesses are conditioned upon prosecutor providing like information, see infra note 36); Missouri (documents, expert reports, witness names, statements); New Mexico (documents, expert reports, witness names, statements); Oregon (documents, expert reports, witness names, statements). Four states allow independent discovery in three categories: Arkansas (defenses, expert reports, witnesses); Colorado (defenses, expert reports, witness names); Idaho (documents, expert reports, witness names); New Hampshire (defenses, expert reports, statements). Six states provide discovery in only two categories, expert reports and documents: Alabama, Connecticut, Maine, New York, Vermont, Wisconsin (also possibility of discretionary disclosure of statements). Four states allow independent discovery in only one category: Alaska (expert reports); Iowa (specified defenses); Maryland (expert reports); New Jersey (defenses). Utah has a discretionary "catch-all" provision that the judge may use to provide for discovery. For specific citations, see infra notes 37-38, 40, 45-47.

The Supreme Court of Michigan has proposed rules of criminal procedure that would allow extensive independent discovery against the defendant, thus permitting discovery in all five categories discussed above. Proposed Michigan Criminal Procedure Rule 6.205 mandates that "the defendant's lawyer, upon request, shall disclose to the prosecutor" any defenses, Proposed Mich. Crim. P.R. 6.205(1); names, addresses, and statements of witnesses, including "written or recorded statements and memoranda summarizing their oral statements," id. Rule 6.205(2); expert reports, id. Rule 6.205(3); and documents and tangible objects, id. Rule 6.205(4). The only restrictions imposed are (1) the defendant must intend to use the evidence at trial and (2) his statement to members of his legal staff are protected. Id. Rule 6.210(D). The proposed rules also give the court discretion to order discovery of any other items from the defendant "if material to preparation of the prosecution," apparently regardless of the defendant's intention to use the evidence at trial. Id. Rule 6.207(A). 
conditioned upon his request for discovery from the prosecution. ${ }^{35} \mathrm{Sev}$ eral states combine conditional and independent prosecutorial discovery. ${ }^{36}$

The scope of prosecutorial discovery permitted in many of these states is very substantial indeed. Under an independent right of discovery, eleven states provide that the defendant is required to inform the prosecution of the nature of his defense. ${ }^{37}$ Fourteen states require the defense to disclose names and addresses of all defense witnesses under an independent right theory, ${ }^{38}$ and ten inore provide for such discovery upon request for discovery by the defendant. ${ }^{39}$

Twelve states give the prosecution an independent right to obtain

35. Florida (documents, expert reports, witness names, witness statements); Mississippi (documents, expert reports, witness names); Nebraska (documents, expert reports, and witness names are discretionary after the defendant requests discovery); Ohio (documents, expert reports, witness names); Pennsylvania (witness names and expert reports are discretionary after the defendant requests discovery); Rhode Island (documents, expert reports, witness names, statements); West Virginia (documents, expert reports, witness names). For specific citations for discovery of defenses and witness names, see infra notes $39 \& 41$.

36. The states that allow independent discovery combined with conditional discovery provisions include: Iowa (expert reports, documents, witness names); New Jersey (expert reports, documents, witness names, statements); and Wisconsin (witness names). See infra notes $39 \& 41$.

New York allows conditional discovery of property that the defendant intends to introduce at trial. It defines property as "including, but not limited to, books, records, reports, memoranda, papers, photographs, tapes or other electronic recordings, articles of clothing, fingerprints, blood samples, fingernail scrapings or hand writing specimens, but excluding attorney's work product." N.Y. CRIM. Proc. LAW § 240.10(3) (Consol. 1982).

Massachusetts allows prosecutorial discovery following a defendant's request for discovery. The statute also operates in a reverse manner by allowing the prosecution to trigger discovery by requesting disclosure of specified items and disclosing similar information to the defense. MASs. $R$. CRIM. P. 14(a)(3)(B). Consequently, Massachusetts discovery statutes have been included under independent discovery categories.

37. ARIz. R. CRIM. P. 15.2(b); ARK. R. CRIM. P. 18.3; Colo. R. CRIM. P. 16 II(c); Haw. R. Penal P. 16(c)(3); Ill. S. CT. R. CRIM. P. 413(d); Iowa R. CRIM. P. 10(11) (limited to defenses of alibi, insanity, intoxication, entrapment, and self-defense); MINN. R. CRIM. P. 9.02 Subd. 1(3)(a); MONT. R. CRIM. P. 46-15-323(4)(a) (limited to defenses of justifiable use of force, entrapment, compulsion, alibi, or absence of state of mind essential to offense); N.H. SUPER. CT. R. 101; N.J. R. Governing Crim. Prac. 3:12A; Wash. Super. Ct. Crim. R. 4.7(b)(2)(XIV).

38. Ariz. R. Crim. P. 15.2(c)(1); ARK. R. Crim. P. 18.3; Colo. R. Crim. P. 16 II(c); Haw. R. Penal P. 16(c)(2)(i); Idaho Crim. R. 16(c)(3); Ill. S. CT. R. Crim. P. 413(d)(i); Mass. R. CRIM. P. 14(a)(3)(A) (discretionary and contingent upon prosecutor providing similar information); Minn. R. CRIM. P. 9.02 Subd. 1(3)(a); Mo: R. CRIM. P. 25.05(A)(2); Mont. R. CRIM. P. 46-15323(4)(a); N.M. Dist. CT. R. CRIM. P. 28(a)(3); OR. ReV. STAT. § 135.835(1) (1984); VT. R. CRIM. P. 16.1(c); WASH. SUPER. CT. CRIM. R. 4.7(b)(1)(i).

39. Fla. R. Crim. P. 3.220(b)(3); Iowa R. Crim. P. 12(3); Miss. UNiform Crim. R. Cir. Cr. Prac. 4.06; Neb. Rev. Stat. § 29-1916 (1985); N.J. R. Governing Crim. Prac. 3:133(b)(3); OHo R. CRIM. P. 16(c)(1)(C); PA. R. CRIM. P. 305(C)(2)(b) (eyewitnesses only); R.I. Super. CT. R. CRIM. P. 16(b)(3); W. VA. R. CRIM. P. 16(b)(1)(C); WIS. R. CRIM. P. 971.23(3).

The nature of the triggering request varies greatly. In Florida, Mississippi, Nebraska, Ohio, and Pennsylvania, disclosure of defense witnesses corresponds to a request by the defendant for discovery of prosecution witnesses. In New Jersey and Rhode Island, a defendant may be required to disclose any discoverable items, including witnesses, following a request for any type of discovery. Wisconsin requires a defendant desiring discovery of prosecution witnesses to state in writing that he is willing 
the statements of all defense witnesses, ${ }^{40}$ and three more permit such discovery from the defendant upon appropriate request by him for discovery. ${ }^{41}$ Moreover, the requirement that the defendant reveal statements of witnesses he intends to call at trial is given a broad readimg in a number of states. The simplest of these expansions defines the term "statement" broadly to require the disclosure of not only written and recorded statements but also "memoranda reporting or summarizing . . . oral statements."42 Some states go a step further and require the defense to create a statement summarizing the testimony expected at trial or the oral statements of its witnesses. ${ }^{43}$ Yet other states require the defense to furmish not only statements of witnesses that it intends to call but also stateinents taken from prospective government witnesses. ${ }^{44}$

to provide a list of his own witnesses to the prosecution. Iowa requires the defendant to disclose witnesses only if the defense deposes government witnesses.

40. ARIz. R. CRIM. P. 15.2(c)(1); Haw. R. Penal P. 16(c)(2)(i) (statements recorded by defense counsel are excluded); Ill. S. CT. R. CRIM. P. 413(d)(i); MASS. R. CR1M. P. 14(a)(3)(A) (discretionary and conditioned upon prosecution revealing similar mformation); MiNN. R. CRIM. P. 9.02 Subd. 1(3)(b); Mo. R. CR1M. P. 25.05(A)(2); MONT. R. CR1M. P. 46-15-323(4)(a) (statements by defendants are excluded); N.H. Super. CT. R. 99; N.M. DisT. CT. R. CRIM. P. 28(a)(3) (statements by defendant to attorneys are excluded); OR. REV. STAT. $\S 135.835(1)$ (1984); WASH. SuPER. CT. CRIM. R. 4.7(b)(I); WIS. R. CRIM. P. 971.24(1) (statements normally disclosed after prosecution has presented its case but court may order disclosure at any time prior to trial upon showing of good cause).

41. Fla. R. Crim. P. 3.220(b)(4)(i); N.J. R. Governing Crim. Prac. 3:13-3(b)(3); R.I. SUPER. CT. R. CRIM. P. 16(b)(4).

In Florida, the defendant must first request statements from the prosecution before the prosecutor can claim a right to discovery of defense statements. New Jersey and Rhode Island allow any request for discovery by the defendant to serve as a basis for discovery of defense statements.

42. See Ill. S. CT. R. CRIM. P. 413(d)(i); see also MinN. R. CR1M. P. 9.02 Subd. 1(3)(b) ("written summaries within [defense counsel's] knowledge of the substance of any oral statements"); MO. R. CRIM. P. 25.05 (A)(2) ("written or recorded statements, and existing memoranda reporting or suinmarizing part or all of their oral statements"); N.J. R. GoVERNING CRIM. PRAC. 3:13-3(b)(3) ("written statements, if any, including memoranda reporting or summarizing [witnesses'] oral statements"); N.M. DiST. Cr. R. CRIM. P. 27(f)(3) (includes written statement or notes that are in substance recitals of oral stateinents).

43. R.I. SUPER. CT. R. CRIM. P. 16(b)(4) ("all written or recorded verbatim statements, signed or unsigned, of [defense witnesses] . . . and, if no such statement of a witness is in the possession of the defendant, a sunmary of the testimony such person is expected to give at trial"); WASH. SUPER. CT. CRIM. R. 4.7(b)(1) ("any written or recorded statements and the substance of any oral stateinents of such witness"); see also N.J. R. GoverNING CRIM. PRAC. 3:13- 3(b)(5) (if no report has been prepared, defense must provide "a statement of the facts and opinions to which the expert is expected to testify and a summary of the grounds for each opinion").

44. MiNN. R. CR1M. P. 9.02 Subd. 1(3)(b) ("defendant shall permit the prosecuting attorney to inspect and reproduce ... statements of prosecution witnesses obtained by the defendant, defense counsel, or persons participating in the defense"); WIS. R. CRIM. P. 971.24 (before witness testifies at trial, his statement "shall be given to the other party"). State v. Lenarchick, 74 Wis. 2d 425, 451, 247 N.W.2d 80, 94 (1976), holds that under this provision defense counsel must provide any statement of a government witness it has: "All statements whether they be in the possession of the direct-examining counsel or the cross-examining counsel are required to be produced."

N.J. R. Governing CRIM. PRAC. 3:13-3(b)(4) contains a similar requirement that the defense provide the prosecution with written statements of any witness the state may call at trial, regardless of whether the defense intends to use the stateinent at trial. In State v. Williams, 80 N.J. 472, 404 
Twenty-two states allow discovery of expert reports under an independent right; ${ }^{45}$ sixteen states inake documents and tangible objects similarly available. ${ }^{46}$ Finally, five states permit the trial court to order discovery from the defense of additional, unspecified materials and inforination upon a showing that it is useful, important, or necessary for the prosecution adequately to prepare its case. ${ }^{47}$

Given the range of information available under prosecutorial discovery, some applications of the rules are likely to require disclosure of incriminating information-such as the defendant's admission that he inflicted the mjury when he provides notice of self-defense. As I argue below, ${ }^{48}$ where incriminating information is required, the constitutionality of discovery under the fifth amendment will depend on the limitations imposed by those rules on when the prosecution may discover information from the defense and how it may use such information once obtained. The rules generally, however, impose few restrictions on prosecutorial discovery that address these concerns.

The defense is uniformly required to provide discovery of defenses

A.2d 34 (1979), the state supreme court held that, as to statements which the defense did not intend to use at trial, the rule violates the defendant's sixth amendment right to effective assistance of counsel.

45. Ala. R. Crim. P. 18.2(c); Alaska Crim. R. 16(c)(4); ARIz. R. Crim. P. 15.2(c)(2); Ark. R. Crim. P. 18.2; Colo. R. Crim. P. 16 II(b); Conn. Super. CT. R. 769(2); Haw. Penal P. 16(c)(2)(ii); IDAho CRIM. R. 16(c)(2); ILL. S. CT. R. CRIM. P. 413(6) (does not include reports that contain statements of defendant if he does not intend to use them at trial); ME. R. CRIM. P. 16A(c); MD. R. CRIM. P. 4-263(d)(2); MASS. R. CRIM. P. 14(a)(3)(A) (discretionary and conditional upon prosecutor providing similar information); MINN. R. CRIM. P. 9.02 Subd. 1(2); Mo. R. CRIM. P. 25.05(A)(1) (does not include portions of reports that contain statements of defendant); MoNT. $R$. Crim. P. 46-15-323(4)(b); N.H. Super. CT. R. 99; N.M. Dist. CT. R. CRIM. P. 28(a)(2); N.Y. Crim. Proc. LAw $\S 240.30(1)$ (a) (Consol. 1982); OR. ReV. STAT. $§ ~ 135.835(2)$ (1984); VT. R. Crim. P. 16.1(b); Wash. Super. CT. Crim. R. 4.7(g); Wis. R. CRIM. P. 971.23(5).

Like Federal Rule of Criminal Procedure 16(b)(1), most other states also provide for conditional discovery of such reports. Because conditional discovery is generally outside the scope of this Article, those states will not be individually listed.

46. Ala. R. CRim. P. 18.2(a); ARIz. R. CRim. P. 15.2(c)(3); ConN. Super. CT. R. 769(2); Haw. Penal P. 16(c)(2)(iii); Idaho Crim. R. 16(c)(1); Ill. S. CT. R. Crim. P. 413(d)(ii); Me. R. Crim. P. 16A(d); MASS. R. CRIM. P. 14(a)(3)(A) (discretionary and conditional upon prosecution's providing similar information); MINN. R. CRIM. P. 9.02 Subd. 1(1); Mo. R. CRIM. P. 25.05(A)(3); MONT. R. CRIM. P. 46-15-323(4)(c) (requiring only list of such items); N.M. DisT. Cr. R. CRIM. P. 28(a)(1); N.Y. Crim. Proc. Law § 240.30(1)(b) (Consol. 1982); Or. Rev. STat. § 135.835(3) (1984); Wash. Super. CT. CRim. R. 4.7(b)(2)(X); Wis. R. CRIM. P. 971.23(4). Most other states provide for conditional discovery and are not specifically listed here.

47. ARIZ. R. CRIM. P. 15.2(f) ("substantial need in the preparation" of the state's case and an inability "without undue hardship to obtain the substantial equivalent by other means"); ILL. S. CT. R. CRIM. P. 413(e) ("[u]pon a showing of materiality . . . and if the request is reasonable"); Mo. R. CRIM. P. 25.06(A) ("reasonable" request for discovery "relevant and material to the state's case"); MONT. R. CRIM. P. 46-15-323(6) ("substantial need, . . . unable without undue hardship to obtain the substantial equivalent by other means, . . . will not violate accused's constitutional rights"); UTAH CODE ANN. $\S 77-35-16$ (c) (1982) ("good cause shown . . . in order for the prosecutor to adequately prepare his case").

48. See infra Part III. 
and the names and addresses of witnesses only if it intends to present the defense or call the witnesses at trial. ${ }^{49} \mathrm{~A}$ number of states also include the undefined limitation, "subject to constitutional limitations." Restrictions on discovery of defense medical and scientific reports vary somewhat between states. Several states, following the 1970 ABA Standards, provide only that disclosure is "subject to constitutional limitations." mtroduce at trial the report or expert testimony to which it relates. ${ }^{52}$ Two states include an additional restriction that such reports are not discoverable if they contam statements of the defendant. ${ }^{53}$ Only two states go further and specifically prohibit the state's use of discovery in its casein-chief; Alaska and Coimecticut restrict the use of such evidence to "cross-examination or rebuttal of defense testimony." 54

Altogether, the developinents noted above constitute a revolution in

49. See, e.g., AR1z. R. CRIM. P. 15.2(c).

50. ARK. R. Crim. P. 18.3; Colo. R. Crim. P. 16 II(c); Ill. S. CT. R. CRIM. P. 413(d); Miss. UNiform Crim. R. CiR. CT. Prac. 4.06; Mo. R. Crim. P. 25.05(A).

51. ARK. R. Crim. P. 18.2; Colo. R. Crim. P. 16 II(b); Miss. UNIForm Crim. R. Cir. CT. PraC. 4.06 ("subject to constitutional limitations" and "made in connection with the case"). Whether the omission of defendant's intention to use the report at trial means that the report may be discovered regardless of the defendant's intention to use the statement is unclear.

Florida imposes only the requirement that they be "made in connection with the particular case." FLA. R. CRIM. P. 3.220(b)(4)(ii). New Hampshire, while not requiring disclosure, permits the court to require exchange of all scientific tests and reports without apparent himitation. N.H. SUPER. CT. R. 99.

52. N.Y. Crim. Proc. Law § 240.30(1)(a) (Consol. 1982); VT. R. Crim. P. 16.1(b); Wash. Super. CT. Crim. R. 4.7(g). PA. R. Crim. P. 305(C)(2)(a) substitutes "defendant's rights against compulsory self-incrimination" for "constitutional limitations."

53. Ill. S. CT. R. CRIM. P. 413(c). MO. R. CRIM. P. 25.05(A)(1).

The Missouri rule combines "constitutional limitations," intention to introduce, and exclusion of statements of the defendant.

In Illinois, the rule combines "constitutional limitations" and the prohibition against discovery of reports that contain the defendant's statements. Apparently, rather than providing a further restriction upon the discovery of such reports, this provision was fashioned to define the full scope of protection under both the fifth amendment and attorney-client privilege. The Comment to the Illinois rule states that unless based upon statements of the defendant, disclosure violates neither attorney-client privilege nor the fifth amendment. It is silent on any requirement that the defense intend to use the expert at trial and appears to impose no such requirement. ILL. S. CT. R. CRIM. P. 413(c) Committee Comments; but see People ex rel. Bowman v. Woodward, 63 Ill. 2d 382, 349 N.E.2d 57 (1976) (where prosecution has no knowledge of tests performed, requiring defendant to disclose any tests conducted violates fifth amendment).

54. Alaska CRIM. R. 16(c)(4); ConN. Super. CT. R. $\$ 772$. Connecticut extends the prosecution's independent discovery right beyond alibi and insanity defenses only as far as documents, physical evidence, and scientific reports. As to those materials, the discovery rules impose four restrictions: (1) the defendant must intend to use the evidence directly or indirectly through the testimony of the witness who prepared the scientific report at trial; (2) documents that contain communications of the defendant are excluded (The provision may be read not necessarily to exclude the entire document from discovery if the defendant's communications are excised.); (3) the document must be "adequately identified by the prosecuting authority"; and (4) these items may be used only on cross-examination and rebuttal of defense testimony. CONN. SUPER. CT. R. $\$ \S 769$, 772. 
criminal discovery with potentially significant detrimental effects upon defendants who wish to present a defense and to undertake independent investigation..$^{55}$ Yet the constitutional limits on these developments have not been clearly established. ${ }^{56}$ The Supreme Court's opinion in Williams v. Florida encouraged these developments but left unanswered most of the critical constitutional questions raised by criminal discovery.

55. The impact on the defense is damaging not only in absolute terms but also in terms of the relative advantages it previously possessed. Obtaining the names of witnesses is the single most critical element of criminal discovery. Of the 13 states that presently provide the most extensive discovery (Arizona, Arkansas, Colorado, Hawaii, Idaho, Illinois, Minnesota, Missouri, Montana, New Mexico, Oregon, Vermont, and Washington), all but four gave witness names to the defense unilaterally before the recent expansion of prosecutorial discovery. See 1969-70 ABA STANDARDS 2.1 Commentary at 56-57. Now the defense must also provide such information to the prosecution.

It should be noted, however, that many defendants have gained by the general expansion of criminal discovery. These developments gave many defendants a relativc advantage by requiring the state to provide the defense some of the fruits of the prosecution's greater investigative resources. Accordingly, due process is generally not offended by these changes since that analysis turns on the overall relative balance of advantage, on whether discovery rules skew that systemic balance against the defendant, see Wardius v. Oregon, 412 U.S. 470, 474 (1973), and in the individual case, on whether the fundamental requisites of justice have been denied. These developments viewed as a whole do not appear to have substantially shifted the relative balance against the defense. Nevertheless, though the general liberalization of discovery may have benefitted many defendants, these changes have adversely affected individual defendants. The issues of the individual's fifth and sixth amendment rights remain to be resolved.

56. Notably, the body most responsible for expansion of prosecutorial discovery in the statesthe American Bar Association-has now reconsidered its position. Under the 1978 Standards on discovery, the $A B A$ requires only that the defense disclose its intention to raise alibi and insanity defenses and provide names and addresses of witnesses supporting those defenses. The information disclosed concerning defenses is explicitly excluded from direct use by thc prosecution as evidence in its case; its use is further limited to refuting the testimony of witnesses called by the defendant. Standards Relating to the Administration of Justice, Discovery and Procedures BEFORE TRIAL $\S 11-3.3$ \& Commentary at 11-54 through 11-56 (Approved Draft 1978) [hereinafter 1978 ABA STANDARDS].

The standard requiring disclosure of defense medical and scientific reports protects any communications from the defendant in such reports from disclosure and similarly limits direct and derivative use of the reports exclusively to refuting the medical or scientific evidence offered by the defense. 1978 ABA STANDARDS $\S 11-3.2$. The commentary explicitly attributes some of these new provisions to the need to protect the defendant's right against self-incrimination and to avoid improper impact on the burden of proof and presumption of innocence. 1978 ABA STANDARDS \$ 11-3.2 Commentary at 11-53 through 11-54.

Unlike the standards approved in 1970, which expanded discovery against the defense and clearly had an enormous impact upon discovery rules in many states, these more restrictive standards have been largely ignored by the states. No explanation is readily apparent. Perhaps the considerable effort by the ABA to implement the standards, see COMPARATIVE ANALYSIS of Standards and Goals of the National Advisory Commission on Criminal Justice

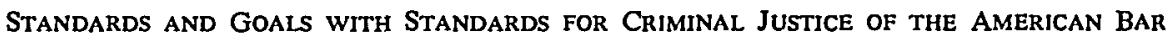
Association vii-ix (1973), was not mounted for the revised Standards. More likely, in contrast to the Standards, the revisions do not fit the tenor of the times. Today's atmosphere is not conducive to providing advantages to criminal defendants, even if only to restore an earlier balance of advantage between the sides. 


\section{Williams v. Florida}

In Williams v. Florida ${ }^{57}$ the Supreme Court examined the constitutionality of Florida's notice of alibi rule under the fifth amendment. ${ }^{58}$ Analysis of the constitutional limits upon prosecutorial discovery must begin with the Williams decision, not because of its clarity in deciding the constitutionality of prosecutorial discovery, but because of its perceived importance as a landmark in the area. Indeed, the guidance the opinion provides for resolution of critical fifth amendment issues presented by such discovery is apparent rather than real.

Petitioner Johnny Williams, who was charged with robbery, wished to present an ahibi defense. As a prerequisite to presenting that defense, Florida law required hin to state where he was at the tinie of the crime and to provide the names and addresses of witnesses he intended to call in support of the alibi. ${ }^{59}$ Williams moved for a protective order, admitting that he intended to rely upon an alibi but seeking to be excused from comphance with the other notice requirements of the statute. The trial court deried the motion. Rather than refuse to provide the required disclosures on the basis that they violated his rights against compulsory self-incrimmation, Williams comphed with the rule and provided the name and address of an alibi witness, Mrs. Scotty. In response, the prosecutor subpoenaed Mrs. Scotty to his office on the morning of trial and deposed her concerning her testimony. ${ }^{60}$

At trial, the defendant presented his alibi that he and his wife had been at Mrs. Scotty's apartment during the tinie of the robbery and called Mrs. Scotty in support. During the cross-examination, the prosecutor twice confronted Mrs. Scotty with inconsistencies between her deposition and her trial testimony. The prosecution also introduced

57. 399 U.S. 78 (1970).

58. Williams also argued that the Florida notice of alibi rule violated his due process rights. The Court quickly dismissed that claim, observing that the state has a legitimate interest in avoiding surprise from "an eleventh-hour" defense and that Florida requires reciprocal disclosures by the state under other provisions of the alibi discovery rule and otherwise provides for liberal discovery by the defendant from the state. Id. at 81-82. It concluded:

We find ample room in [the adversary] system, at least as far as "due process" is concerned, for the instant Florida rule, which is desigued to enhance the search for the truth in the criminal trial by insuring both the defendant and the State ample opportunity to investigate certain facts crucial to the determination of guilt or innocence.

Id. at 82 .

59. Fla. R. CRim. P. 1.200 and 33 Fla. Stat. ANN. (West 1967). The rule has been renumbered and is now FLA. R. CRIM. P. 3.200 (West 1973).

60. Florida criminal procedure permitted both the prosecutor and the defense to depose opposing witnesses prior to trial. The prosecutor could depose witnesses at any time-either before or after the defendant had been formally charged. FLA. STAT. ANN. $\$ \$ 27.04,32.20$ (West 1961). Defense counsel had no right to be present during such questioning. The defendant could depose all witnesses, except confidential informants, after formal charges had been instituted. FLA. R. CRIM. P. 1.220(f) and 33 FLA. STAT. ANN. (West 1967). 
rebuttal testimony from a police officer who stated that at the time Williams was allegedly with Mrs. Scotty in ler apartment sle was actually elsewliere.

Petitioner's major claim was that the alibi notice rule violated his rights under the fiftl and fourteenth amendments by requiring him to provide the state with "imformation useful im convicting him." 61 The Court lield that the rule did not violate the defendant's privilege against self-imcrimination because his compliance with the rule had not been compelled within the meaning of the fifth amendment.

In assessing the defendant's fifth amendment claim, the Court held three elements were necessary to find a fiftl amendment violation. First, the evidence must be testimonial in nature. ${ }^{62}$ Second, the danger of selfincrimination must be "real and appreciable." ${ }^{63}$ Third, the witness must be subjected to "physical or inoral compulsion." 64 Altlough the Court was willing to assume that the defendant's discovery disclosure was both testimomal and imcriminating, it concluded that the privilege against compulsory self-imcrimination was not violated because "the alibi defense ... cannot be considered 'compelled' within the meaning of the Fifth and Fourteenth Amendments."65

The Court noted that at trial a criminal defendant often faces powerful pressures to call witnesses or to testify in his own behalf in an attempt to avoid conviction. That he faces such pressures and may respond to them by putting on testimony that ultimately leads to his undoing has never been viewed as violating the fifth amendment. Such pressures, even though very powerful, simply do not give rise to the sort of coinpulsion recognized by the privilege against self-incrimination. The Court concluded that state enforcement of a notice of alibi rule inposes similar constraints and pressures upon the defendant, and apparently nothing more. Accordingly, the operation of the rule produces no more cognizable state compulsion than the defendant's own decision to testify or adduce evidence.

The Court did acknowledge that the decisions faced by the defendant under the rule and at trial differ in one obvious respect. The notice of alibi rule requires him to "accelerate the timing of his disclosure, forcing him to divulge at an earlier date information that the petitioner from the beginning planned to divulge at trial." ${ }^{\text {"66 }}$ Nonetheless, the Court did not

61. Williams, 399 U.S. at 82.

62. Schmerber v. California, 384 U.S. 757, 761 (1966).

63. Brown v. Walker, 161 U.S. 591 , 599 (1896) (quoting Regina v. Boyes, 1 Best \& Smith 311, 330, 121 Eng. Rep. 730, 738 (Q.B. 1861)).

64. Periman v. United States, 247 U.S. 7, 15 (1918) (emphasis added); Fisher v. United States, 425 U.S. 391,397 (1976) (emphasis added).

65. Williams, 399 U.S. at 84.

66. Id. at 85 . 
consider the difference in timing alone a constitutionally critical one.

Nothing in the Fifth Amendment privilege entitles a defendant as a matter of constitutional right to await the end of the State's case before announcing the nature of his defense, any more than it entitles him to await the jury's verdict on the State's case-m-chief before deciding whether or not to take the stand himself. ${ }^{67}$

Williams appears to say that acceleration in the timing of disclosures that the defendant intends to inake at trial entails no constitutionally significant coinpulsion. This is the principal holding of Williams, and its application and expansion represent that decision's chief impact upon criminal discovery. Since compulsion is a necessary eleinent of a fifth amendment violation, Williams seems to mean that even where the evidence in question is highly incriminating and unmistakably testimomal in character, the prosecution may "obtam under threat of sanction complete disclosure by the defendant in advance of trial of all evidence, testimony, and tactics he plans to use at that trial." 68

The Court's decision rests on two critical premises. First, it relies on the unassailable position that a criminal defendant's decision to present an alibi defense at trial is not compelled within the meaning of the fifth anendment even though it may be the product of powerful forces bearing upon him. Second, it assumes that the forces and pressures acting upon a defendant faced with the requirement of giving an alibi notice are of the same nature. Thus, the Court concluded, "In the case before us, the notice-of-alibi rule by itself in no way affected petitioner's crucial decision to call ahibi witnesses or added to the legitimate pressures leading to that course of action." 69

Though the Court recognized that providing advance notice of an alibi differs from the presentation of the defense at trial in that it requires earlier specification of the defense, it assumed that the difference was not constitutionally significant. ${ }^{70}$ Rules requiring pretrial disclosure of defenses, however, may implicate the fifth amendment in two important respects-neither of which was present in Williams.

First, the rule may have a significant impact upon the interests protected by the fifth amendment depending upon the evidentiary nature of the disclosure itself. By requiring the defendant to provide notice of his defense, the state requires him to "speak," and the speech itself may have evidentiary significance. For example, under the state's evidentiary law, the notice may be considered an admission by the defendant that may be

67. Id.

68. Id. at 114 (Black, J., dissenting).

69. Id. at 85 .

70. For a discussion of the testimonial aspects of discovery see infra notes 161-68 and accompanying text. 
used either directly to establish his guilt or to impeach him if his trial testimony is imconsistent with his notice.

Second, the rule may implicate the fifth amendment depending upon the timing of the disclosure. By directing the defendant to provide the prosecutor with information before the state has completed its case, the rule may require the defendant to assist the state in proving its case against him. The timing of the disclosures will have great significance if the defendant's "statement" is used to strengthen the government's casem-chief, $m$ addition to helping defeat the defense.

A notice of alibi rule such as Florida's may harm ${ }^{71}$ a criminal defendant's prospects for success at trial im either or both of these ways. Several fact patterns are possible. First, the prosecution may be able to use the notice to obtain other information that strengthens its case against the defendant. Clearly, derivative use by the prosecution of any witness identified by the notice poses a problem. For example, the defendant may have an alibi that puts him so close to a crime scene that it corroborates some aspects of the government's case. The prosecution can then preempt the defense's presentation of that witness's testimony accordingly. The state may call the witness first to testify that the defendant arrived in the vicimity at a certain time-as the state's witness would testify the perpetrator of the crime did-even though the details of the alibi, if later fully accepted, would put him in another location at the precise time of the crime. ${ }^{72}$ Second, the notice may provide collaterally damaging information. For example, the alibi inay connect the defendant with nefarious imdividuals who are able to incriminate him in other crimes. ${ }^{73}$ Third, early disclosure may provide the government with opportumities to obtain impeachment evidence, otherwise unavailable, that would be used to weaken the defense case. Fourth, the notice itself

71. I use "harm" rather than "incriminate" advisedly. Some consequences that disadvantage a defendant are not sufficient to constitute "incrimination." For instance, the Court in Williams declined to hold that the fifth amendment guaranteed the defendant the right to surprise the state with his defense. 399 U.S. at 86 . See infra note 76.

72. Professor Nakell used a similar example to explain how advance specification of a defense might require a defendant to provide information that is at least partially incriminating. Nakell, supra note 9, at 500 . Other examples of defenses that are exculpating but potentially incriminating when specified in advance of trial are: provocation, which supports a lenient sentence but also provides an incriminating motive, Alschuler, The Trial Judge's Role in Plea Bargaining, Part I, 76 CoLUM. L. REV. 1059, 1118 (1976), self-defense which establishes incidentally the identity of the perpetrator, and a defense to the major offense that establishes guilt of a lesser one, Prudhomme v. Superior Court, 2 Cal. 3d 320, 327, 466 P.2d 673, 677, 85 Cal. Rptr. 129, 133 (1970); Van Kessel, Prosecutorial Discovery and the Privilege Against Self-Incrimination: Accommodation or Capitulation, 4 Hastings Const. L.Q. 855, 861 n.33 (1977); Note, Prosecutorial Discovery Under Proposed Rule 16, 85 HARV. L. REV. 994, 1004-05 (1972).

73. While frequently cited as an example of the incriminating potential of alibi notice, see, e.g., Scott v. State, 519 P.2d 774, 785 (Alaska 1974), the potential incrimination presented here does not rise to the level prescribed by the fifth amendment. See infra notes 197-203 and accompanying text. 
may be used to impeach a defendant's testimony if he presents any other mconsistent defense. ${ }^{74}$ Finally, the requirement that a defendant give notice of alibi requires him to assist the state in even more subtle ways. For example, the notice tells the state that it inust meet only the defense specified, thereby allowing it to focus its efforts. ${ }^{75}$

The Williams case touched on several of these potential adverse consequences of the notice of alibi rule. It did not decide, however, whether the fifth amendment would have been violated by any of thein because there was no evidence in the record that Williains had suffered any concrete harm as a result of his disclosure. After Willianns's inotion for a protective order was denied by the trial court, he gave the required notice and presented his alibi. Because of the procedural posture in which petitioner raised his claims, the facts were fully available. Those facts in no way suggested, nor did Williams allege, that the government used the notice either directly or derivatively to enhance the strength of its casein-chief or that there was any reasonable prospect that it would give rise to other, independent prosecutions. ${ }^{76}$

74. Cf. In re Misener, 38 Cal. 3d 543, 698 P.2d 637, 213 Cal. Rptr. 569, (1985) (requirement that defense disclose statements of its witnesses after their direct testimony, designed to facilitate their impeachment, lightens state's burden to prove defendant's gnilt and violates California's constitutional right against self-incrimination).

75. Van Kessel, supra note 72, at 888-89. Professor Van Kessel concludes that such a consequence does not threaten the values supporting the privilege sufficiently to violate the fifth amendment. Id. at 889. The result in Williams supports his position. See infra note 81; See also infra note 164. But see Jones v. Superior Court, 58 Cal. 2d 56, 65-66, 372 P.2d 919, 925, 22 Cal. Rptr. 879,885 (1962) (Peters, J., dissenting) (allowing state to determine whether defendant intends to rely solely on not guilty defense or urge affirmative defense "emasculates" defendant's constitutional rights).

76. At oral argument, counsel for Williams, when pressed, admitted "[t]here may not be anything 'incriminating" " in the disclosure under the facts of this case. 69 LANDMARK BRIEFS AND ARguments of the SuPReme Court of the United States: Constitutional LaW 416 (P. Kurland \& G. Casper ed.) [hereinafter LANDMARK BRIEFs]. His ultimate response to the Court's question of how the alibi notice incriminated him rested solely on the proposition that a criminal defendant has an "absolute right to remain silent up until the very close of the State's case." Id. The closest petitioner came to arguing that the state used his notice of alibi against him was his contention that if he had decided not to present the alibi defense after giving notice his failure would "certainly become known to the jury by way of opening and closing statements." Brief for Petitioner at 6, Williams v. Florida, 399 U.S. 78 (1970), reprinted in LANDMARK BRIEFS, supra, at 331. The case in fact proceeded otherwise, however. Petitioner announced his defense in his opening statement; the state responded only after the alibi witness testified. Williams, 399 U.S. at 84 n.15. Indeed, the Court was able accurately to say, "Nothing in [the alibi notice rule] . . requires the defendant to rely on an alibi or prevents him from abandoning the defense; these matters are left to his unfettered choice." Williams, 399 U.S. at 84.

The Court did not explain fully what it meant by this statement. It may have been referring to the state's concession, in its brief, that if petitioner chose not to present an alibi defense after giving notice, federal constitutional principles prohibited a negative inference. Brief for Petitioner at 8-9, Williams v. Florida, 399 U.S. 78 (1970), reprinted in 69 LANDMARK BRIEFs 352-53. The Court seemed hesitant to rely upon that protection for the defendant, making no direct comment upon it. Perhaps this is because the prosecution relied, not on state law, but on federal fifth amendment law. The Court suggested that it might reach a different conclusion on the constitutional issue, observing 
The state did use the information it obtained as a result of Williams's notice to weaken his case in two concrete ways. It impeaclied Mrs. Scotty twice witl portions of the deposition obtained after her identity was revealed under tlie rule. Also, the information that either Wilhams provided directly in lis notice or the state obtained indirectly througli Mrs. Scotty's deposition permitted the state to locate a witness to rebut lier testimony. The Court found this use of the alibi notice of no consequence because, as Williams acknowledged, the state could have achieved the same result by obtaining a continuance as soon as Williams called the witness. ${ }^{77}$ During that continuance, which the Court assumed would violate no constitutional provision, the state could have done exactly what it did here-take a deposition and find rebuttal evidence.

Based on this factual analysis of Williams, it is easy to agree with the Court's conclusion, at least in this case, that

the pressures that bear on [a defendant's] pretrial decision are of the same nature as those that would induce him to call abibi witnesses at the trial: the force of historical fact beyond both his and the State's control and the strength of the State's case built on these facts. ${ }^{78}$

The Court's further determination in Williams that the notice of alibi rule did not affect Williams's decision to call alibi witnesses or add to the inherent pressure flowing from historical facts to call tliem is equally accurate.

Ultimately, the notice of alibi rule at issue in Williams liad no impact on the defendant's conduct of his trial. It did not directly create evidence or permit the state to present evidence in its case-in-clief that otlerwise would liave been unavailable. Williams's "statement" was not given any evidentiary significance in tlie case, and no incriminating evidence caine directly or derivatively from the requirennent that lie "speak" before the state's case was completed. ${ }^{79}$ On the facts of Williams, then, the Court reached the correct result.

that restrictions on changes in defenses would not necessarily offend the Constitution. Williams, 399 U.S. at $84-85$ n. 15 .

Rather than reacting to the state's concession, the Court was more likely commenting upon the specific factual record before it. Petitioner made this argument in general but did not allege that "his choice of defense at trial in this case would have been different but for his prior compliance with the rule." Id. at 84 n.15.

77. Id. at $85-86$.

78. Id. at 85 (emphasis added).

79. The Court's brief treatment of the alibi notice as testimonial conduct implies that the Court anticipated no evidentiary use of the notice, or other use of the information it contained, to assist the state in proving relevant historical facts. Justice White suggested that "' 'testimonial' disclosures protected by the Fifth Amendment include only statements relating to the historical facts of the crime, not statements relating solely to what a defendant proposes to do at trial." Id. at $86 \mathrm{n} .17$ (emphasis added). Only if the notice is given no direct evidentiary use at trial and if it is not used derivatively to incriminate is this suggestion sensible. Cf. Berger, Man's Trial, Woman's Tribulation: Rape Cases in the Courtroom, 77 CoLUM. L. REv. 1, 74 n.425 (1977) (Justice White's contention, 
Williams itself raises the larger issue of the validity of prosecutorial discovery in other contexts only when the fifth amendment is viewed from the absolutist perspective that the Constitution protects the defense from any required disclosures. In dissent, Justice Black argued that the state may require nothing of the defendant that might conceivably ligliten the government's load or provide "assistance . . . in convicting him." ${ }^{80}$ The Court rejected that position, ${ }^{81}$ but decided nothing more. ${ }^{82}$ The Court's holding reveals little about the constitutional limits on prosecutorial discovery because there were no specific fifth amendment interests implicated by the facts of the case. ${ }^{83}$ To discover these limits,

which has no precedential basis, relates solely to matters of trial strategy, not matters of evidence); see also infra note 163.

80. Williams, 399 U.S. at 111 (Black, J., dissenting).

Justice Black, taking this broad view of the fifth amendment in dissent, saw no need to examine the "practical effects" of the notice of alibi; he found the rule to be "a patent violation of [the privilege against self-incrimination] because it requires a defendant to disclose information to the State so that the State can use that information to destroy him." Id.

81. Justice White, for the majority, stated, "Nothing in the Fifth Amendment privilege entitles a defendant as a natter of constitutional right to await the end of the State's case before announcing the nature of his defense," $i d$. at 85, or "guarantees the defendant the right to surprise the State with an alibi defense." Id. at 86.

82. Despite the holding's himits, it would be wrong to denigrate its significance. Indeed, Williams provided one of the first signals that the Court would tolerate substantial limitations on the scope of the privilege. It was one of the first cases to sound the theme that not every burden on the fifth amendment right and not every pressure against its exercise violates the Constitution, a position articulated directly or reflected in the holding of numerous cases decided over the course of the next decade. See, e.g., Jenkins v. Anderson, 447 U.S. 231 (1980); Lakeside v. Oregon, 435 U.S. 333 (1978); Baxter v. Palmigiano, 425 U.S. 308 (1976); California v. Byers, 402 U.S. 424 (1971); McGautha v. California, 402 U.S. 183 (1971).

Indeed, the California Supreme Court departed from the United States Supreme Court's interpretation of the fifth amendment at this fundamental juncture, adopting under the state constitution Justice Black's extreme view of the privilege against self-incrimination. Prudhounme v. Superior Court, 2 Cal. 3d 320, 326, 466 P.2d 673, 677, 85 Cal. Rptr. 129, 133 (1970) (The California constitution prohibits discovery that "conceivably might lighten the prosecution's burden of proving its case in chief."); In re Misener, 38 Cal. 3d 543, 555, 698 P.2d 637, 645-46, 213 Cal. Rptr. 569, 57778 (1985) (Requiring disclosure of defense witness statements for impeachment by the state "would be of use to the prosecution in securing a conviction [and] would for that reason be incriminatory, and thus privileged.").

Because analysis of discovery under the California constitution differs so radically from that under the fifth amendment, this Article includes no discussion of developments in California.

83. Analysis of the difference between pretrial discovery of information from the defendant and his own presentation of that same information at trial, may focus on a number of factors: (1) the timing of the disclosure and the use the prosecution may make of it, see Van Kessel, supra note 72, at 882; (2) the degree to which the disclosure may "incriminate," see Alshuler, supra note 72, at 1118 n.201; Nakell, supra note 9, at 499; (3) the uncertainty created by requiring the defendant to make a choice of defenses before trial, see, Westen, Order of Proof: An Accused's Right to Control the Timing and Sequence of Evidence in His Defense, 66 CALIF. L. REv. 935, 949-52 (1978) (focusing on the uncertainty faced by the defendant as an important factor in the Court's analysis); and (4) the extent to which these factors compel, in the sense of coerce, the defendant to alter his decision to testify, see 3 W. Lafave, Search and Seizure $\$ 11.2$ at 266 (1986 Supp.); Note, The Use of Suppression Hearing Testimony to Impeach, 59 IND. L.J. 295, 305-06 (1984).

Williams reveals little about the relative importance of any of these factors. The most that can 
one must examine other Supreme Court opimions analyzing the compulsion issue under the fifth amendment. I will examine the models of compulsion used by the Court in cases challenging prosecutorial practices under the privilege against self-incrimination. Then, im Part III, I apply these models of compulsion to various hypothetical discovery rules in an attempt to define the constitutional limits of the Williams Court's approval of prosecutorial discovery.

\section{II}

\section{COMPULSION UNDER THE FifTH AMENDMENT}

Because the Williams decision can be imterpreted to inean that compulsion is never present in the typical discovery situation, a careful examination of the Supreine Court's treatment of compulsion is of central importance to the constitutional analysis even though compulsion is but one of the three prerequisites to a fifth amendment violation. ${ }^{84}$

The Supreme Court cases analyzing compulsion fall into two groups. In the first group, the Supreme Court invalidates state practices because they threaten the defendant with sanctions external to the trial process, often for the purpose of producing testimonial assertions that may be used in a criminal prosecution. In the second group, there are no external sanctions; instead, operation of the rule impairs the defendant's fifth amendment interests to a certain degree. In this situation, the Court in some circumstances weighs the policies behind the fifth amendment riglit affected agamst the state's interest in the practice, or the Court may simply conclude that, employing a facially different treatment of the issue, the practice "burdens" the exercise of the fifth amendment and therefore is necessarily unconstitutional.

Such varyimg treatment of the coinpulsion issue can be best understood by viewing the cases as creating two models of compulsion. The first, which may be termed the pristine model, covers cases in group one above: the individual is subjected to direct, external sanctions for his refusal to speak. The second model covers the cases in the second group irrespective of the Court's apparently differing treatment. Here the defendant is not threatened with direct, external sanctions, but claims that the state practice in question indirectly penalizes him for exercising his fifth ainendment rights, and the Supreme Court uses a balancing process to determine whether unconstitutional compulsion is present. This second inodel explains both the cases in which the Supreme Court explicitly weighs the threats to policies behind the fifth amendment against the

be gleaned from the case is that the coercive effect of uncertainty generated by prosecutorial discovery standing alone does not create compulsion forbidden by the fifth amendment in every case. These arguments will be addressed in Part III, infra.

84. See supra notes $62-64$ and accompanying text. 
state's interest and those in which the Court declares the practice invalid simply because it burdens the defendant's contitutional rights. ${ }^{85}$ State discovery practices will fall primarily under the second model, and their constitutionahty must be evaluated by its standards.

Under the second model, key factors in the balance are the state's purpose in exerting the pressure, the strength of its policy supporting the disclosure independent of an interest in obtaining incriminating statements, and the nature and degree of impact of the practice upon the values protected by the fifth amendment. While coercive state pressure inust produce incriminating testimonial evidence to violate the fifth amendinent, ${ }^{86}$ the second inodel does not focus primarily on the precise nature of that coercive pressure as does the pristine model. Instead, the Court looks to how the state may use the information it obtains from the defendant.

\section{A. Compulsion in Its Pristine Form}

New Jersey v. Portash ${ }^{87}$ illustrates use of the pure compulsion model. There the Court described testimony under legislative immumity before a grand jury as "the essence of coerced testimony"-_"the constitutional privilege against compulsory self-incrimination in its most pristine form." 88 Such testimony before the grand jury presents a modern version of the historical practice that is generally credited with producing the fifth amendment-calling a witness under the oath ex officio and confronting him with the "cruel trilemma of self-accusation, perjury or contempt."89

85. The broad outlines of this analysis have been developed elsewhere. Arenella, Schmerber and the Privilege Against Self-Incrimination: A Reappraisal, 20 AM. CRIM. L. REV. 31, 34-35 (1982); see also M. BERGER, TAKING THE FIFTH 193-219 (1980). Regrettably, despite development of that analysis, the lower courts continue to treat compulsion either as present only when external sanctions are threatened or as an issue without rational resolution. See McCracken v. Corey, 612 P.2d 990, 993-95 (Alaska 1980) (no pattern can be found in decided cases to distinguish between impermissible compulsion and permissible pressures inherent in difficult strategic choices facing a defendant). With respect to pretrial discovery generally, the result has been the virtual denial of the possibility of a viable fifth amendment claim. It is my hope that clarification and expansion of this analysis will render it more persuasive to the courts and bring greater rationality to the resolution of these cases.

86. The coercive pressure in the discovery context is provided by a state statute, rule, or court order that requires the defendant to provide disclosures or suffer a significant penalty, often the exclusion of evidence or testimony.

87. 440 U.S. 450 (1979).

88. Id. at 459 . "In such cases there is no question whether physical or psychological pressure overrode the defendant's will; the witness is told to talk or face the government's coercive sanctions, notably, a conviction for contempt." Id.

89. Murphy v. Waterfront Comm'n, 378 U.S. 52, 55 (1964); see also L. LEVY, ORIGINS OF THE FifTh AMENDMENT (1968); 8 J. Wigmore, EvidenCE $\S 2250$ (McNaughton rev. 1961); Nakell, supra note 9, at 481-88.

The Court has expanded in modern-day contexts the type of external coercive force that may 
According to the Court, a person cannot constitutionally be coerced into such a choice by the penalty of contempt or its modern-day economic variant. ${ }^{90}$ When faced with such compulsion, he may refuse to answer "unless and until he is protected at least against the use of his coinpelled answers and evidence derived therefrom in any subsequent criminal case . . . , [and] [a]bsent such protection, if he is nevertheless coinpelled to answer, his answers are inadınissible against hiln . . .."91

produce the "core" or "pristine" form of compulsion. In Marchetti v. United States, 390 U.S. 39 (1968) and Grosso v. United States, 390 U.S. 62 (1968), compulsion was found in the operation of independent criminal statutes requiring gamblers to furnish tax information that would subject them to criminal prosecutions for their gambling activities. Subsequently, in a series of cases spanning a decade, the Court expanded the definition of compulsion beyond a threat of imprisonment to include economic sanctions such as the loss of employment, Garrity v. New Jersey, 385 U.S. 493 (1967); Spevack v. Klein, 385 U.S. 511 (1967), the right to secure public contracts, Lefkowitz v. Turley, 414 U.S. 70 (1973), and the loss of the right to hold an office in a political party entailing both social prestige and economic benefits, Lefkowitz v. Cunningham, 431 U.S. 801, 806-07 (1977).

90. See supra note 89 .

While the full range of prohibited sanctions outside contempt has not been defined, it includes other "potent sanctions" beyond "direct economic sanctions and imprisonment." Lefkowitz v. Cunmingham, 431 U.S. at 805-06. Civil sanctions must be imposed "automatically and without more" upon refusal to waive the privilege to constitute compulsion. Id. at $808 \mathrm{n} .5$ (citing Baxter v. Palmigiano, 425 U.S. 308 (1976)).

In Baxter, the Court held that in non-criminal prison disciplinary proceedings the fifth amendment permitted respondent's silence to be used against him. Since the proceedings themselves were not criminal, the fifth amendment did not apply directly. Rather, it applied only if the sanction in the civil proceedings constituted compulsion under the fifth amendment which might eause respondent to provide statements that could be used in a later criminal case against him. Also, unlike the situation in the economic penalty cases, no loss of job, for example, would automatically follow his refusal to provide the requested information. Under these circumstances, the Court held that an inference upon silence utilized only as a factor in determining whether the prisoner would be disciplined was not a sufficient sanction to constitute compulsion.

91. Lefkowitz v. Turley, 414 U.S. at 78.

A witness may vindicate his fifth amendment privilege by either (1) refusing to provide the testimony and defending against imposition of the sanction under the fifth amendment or (2) invoking the privilege and, if the assertion is not honored, providing the testimony and moving at any subsequent trial to have the testimony excluded. Thus, a person faced with this choice will be protected, with certain limitations, by the fifth amendment, whichever choice he makes. See Westem \& Mandel, To Talk, to Balk or to Lie: The Emerging Fifth Amendment Doctrine of the "Preferred Response", 19 AM. CRIM. L. REv. 521 (1982) (state may require the defendant to litigate fifth amendment claims in a specified manner if the mechanism prescribed will fully protect those rights). The sanction that will compel within the meaning of the privilege is equal to the sanction or penalty prohibited by the privilege from being imposed upon the exercise of the right.

Professor Westen has described the relationship as follows:

The privilege [against self-incrimination] prohibits the state from putting a person to the cruel choice of either becoming a witness against himself or suffering a penalty for remaining silent. Accordingly, the constitutional interests of a defendant who has heen put to such a choice are violated regardless of whether he responds to the dilemma by taking the witness stand over his objection or by suffering a penalty for remaining silent. Whichever his response, he suffers constitutional injury because he should never be put to the choice in the first place. In other words, there is a relationship of equivalencc between penalties and compulsion. A "penalty" on the privilege against self-incrimination is the kind of illicit pressure on a defendant to become a witness against himself which, if it is effective as a threat would "compel" him to take the witness stand over his objection.

Westen, supra note 83, at 942 (footnotes omitted); cf. Chaffin v. Stynchcombe, 412 U.S. 17, 31-32 
No state interest, regardless of its strength, justifies such coinpulsion, ${ }^{92}$ and the testimony obtained may not be used for any purpose against the individual, not even to impeach him..$^{93}$

The pristime model of compulsion and its attendant principles are not directly apphicable to existing discovery practices because the defendant is not faced with direct, external sanctions for his refusal to provide the requested disclosures. The second model of compulsion provides the analytical frainework for determining the constitutional himits of typical discovery requirements.

\section{B. The Second Compulsion Model-The Balancing of Interests}

The Court has been far less clear with the second model ${ }^{94}$ in specify-

n.19 (1973) (Court's focus is on whether the practice "created a burden on the exercise of the right to remain silent, or, stated differently, encouraged its waiver.").

92. Lefkowitz v. Cunningham, 431 U.S. 801, 808 (1977) ("We have already rejected the notion that citizens may be forced to incriminate themselves because it serves a governmental need" even where governmental interest is substantial and alternative methods of promoting state aims are not apparent.); see also New Jersey v. Portash, 440 U.S. 450, 459 (1979) (balancing state interest in preventing perjury against deterrence of unlawful police conduct impermissible where statements compelled); $c f$. Marchetti v. United States, 390 U.S. 39, 60-61 (1968) (important governmental interest in accurate fiscal information insufficient to justify violation of fifth amendment where information could be obtained by methods consistent with constitutional guarantees).

Of course, where the privilege is protected through the grant of immunity, persons not responding to government inquiry may be sanctioned. Lefkowitz v. Turley, 414 U.S. at 84 ("[G]iven adequate immunity, the State may plainly insist that employees either answer questions under oath about the performance of their job or suffer the loss of employment.").

93. New Jersey v. Portash, 440 U.S. 450 (1979).

94. Whether it is appropriate to describe the cases as fitting into two models of compulsion can be debated. On the one hand, terminology other than "compulsion" might be used to explain these results, such as the unconstitutionality of requiring that one right be "forfeited" in order to exercise another. See, e.g., Simmons v. United States, 390 U.S. 377, 393-94 (1968); Garrity v. New Jersey, 385 U.S. 493, 500 (1967). On the other, at least some of the discovery practices I examine are arguably unconstitutional without resort to a second model-because they involve compulsion in the pristine sense. My difficulty with either of these positions is that both ultimately require a balancing of interests to decide specific cases. I believe, therefore, that the first step of analysis should examine the interests involved.

Analyzing the issue in terms of the unconstitutionality of requiring one right to be forfeited so that another may be exercised ignores the key question of compulsion. Unless a defendant is compelled to speak, his fifth amendment rights are not violated; the simple fact that tension exists between the exercise of two rights does not mean that one is violated. Using "forfeiture" terminology provides no useful guidance for determining when that tension rises to an unconstitutional level. Finally, in order to determine which practices are invalid, the court must inevitably evaluate and weigh the interests behind the exercise of competing rights. The appropriate beginning point is just such an interest analysis. See generally Westen, Incredible Dilemmas: Conditioning One Constitutional Right on the Forfeiture of Another, 66 IowA L. REv. 741 (1981).

In a different analysis, compulsion in its pristine form is arguably present when a discovery rule requires the defendant to provide incriminating, testimonial evidence that aids the state in convicting him and threatens exclusion of undisclosed evidence as a sanction for noncompliance. Although the Supreme Court has not directly addressed this issue, its descriptions of pristine compulsion seem to require external sanctions of a type not present here. Though the perimeters of the pristine model might reasonably be expanded to include this factual situation, and such expansion would be 
ing the dimensions of the fifth amendment right. In some cases, the Court has simply stated that a state practice that imposes a burden upon the exercise of the fifth annendment right is invalid. In others, the Court has exphicitly used a balancing approach.

The second model of coinpulsion began with Griffin v. California, ${ }^{95}$ in which, for the first time, the Court found a violation of the fifth amendment despite the absence of external compulsion. In Griffin, the Court invalidated California's practice of permitting comment by both the court and the prosecutor on a defendant's failure to testify. The defendant faced no compulsion in terms of a penalty external to the trial process, such as imprisonment or an econornic sanction, operating automatically upon his exercise of the right to remain silent.

In holding that the practice unconstitutionally burdened the defendant's fifth amendment rights, the Court sidestepped the issue of compulsion entirely. The Court made no attempt to explain how comment on the defendant's silence compelled him to incrimmate himself. ${ }^{96}$ Instead, it analyzed the practice in ternis of the burden it placed on the defendant's assertion of his right to remain silent. Thus, it held that a comment upon silence is invalid under the fifth amendment because it "is a penalty imposed by courts for exercismg a constitutional privilege. It cuts down on the privilege by making its assertion costly."97 The Court found fur-

consistent with the fundamental purpose of the fifth amendment, such expansion is unlikely for two reasons. First, the present Supreme Court shows no inclination in that direction. If anything, the historically based definition of compulsion appears to be assuming greater importance. Second, in determining this expanded core meaning of compulsion, something very similar to the balancing process, which I describe, would have to be used. Once the Court moves away from defining compulsion by comparing the challenged practice in modern contexts to the historically based external-sanction model, it must analyze the values behind the right and can no longer use directly the pristine model. Indeed, it is hard to see how any discovery practices could be found to violate the privilege against self-incrimination if these values are ignored. As a result, whether the analytical process is termed a second model or not, an analysis of the competing interests must be used to determine when compulsion is present.

95. 380 U.S. 609 (1965).

It is apparent that the situation and language of Griffin are different from the economic sanction cases. There was no clear difference, however, in the Court's initial treatment of these issues. Justice Douglas wrote both Griffin and the first of the "employment cases," Garrity v. New Jersey, 385 U.S. 493 (1967). In Garrity, he described the fifth amendment almost precisely in the language of Griffin-as one of those "rights of constitutional stature whose exercise a State may not condition by the exaction of a price." 385 U.S. at 500.

96. In dissent, Justice Stewart, joined by Justice White, found compulsion to be entirely lacking even though he would have made it the "focus of the inquiry." He argued: Any possible compulsion would be of "a dramatically different and less palpable nature than that involved in the procedures which historically gave rise to the Fifth Amendment guarantee. . . . I think that the Court in this case stretches the concept of compulsion beyond all reasonable bounds ...." Griffin, 380 U.S. at 620; see also Ayer, The Fifth Amendment and the Inference of Guilt from Silence: Griffin v. California after Fifteen Years, 78 Mich. L. REv. 841, 852-66 (1980).

97. Griffin, 380 U.S. at 614.

Commentators have attempted to explain Griffin in a number of ways. One suggests that the opinion correctly balanced a weak and almost irrational state interest in being able to infer guilt from 
ther that the practice undermined the values behind the fifth amendinent, considering it reminiscent of the "inquisitorial system of crininal justice." $" 98$

Similarly, in Simmons v. United States, ${ }^{99}$ the Court found a practice unconstitutional because it rendered the assertion of a constitutional right too costly. It ruled that statements made by a defendant at a suppression hearing to establish his standing to contest the validity of a search could not be used as evidence of guilt at his subsequent trial. The Court recognized that as an "abstract matter" the testiniony was voluntary and was not strictly compelled within the meaning of the fifth amendment. Nevertheless, requiring the defendant to forfeit his right to testify im support of his fourth amendment claim in order to preserve his fifth ainendment right to silence created "an undemable tension." The Court concluded, " $\mathrm{m}$ these circumstances ... . it [is] intolerable that one constitutional right should have to be surrendered in order to assert another."100

It was not until McGautha v. California ${ }^{101}$ that the balancing approach of the second model of compulsion emerged. In McGautha, petitioner argued that Ohio's unitary procedure for determining guilt and pumshinent in a capital case created an unconstitutional tension between his fifth amendinent right to remain silent as to guilt and his due process right to be heard on the issue of punishinent. The Court immediately rejected the suggestion in Griffin that all burdens on the exercise of fifth amendinent rights are unconstitutional.

Although a defendant may have a right, even of constitutional dimensions, to follow whichever course he chooses, the Constitution does not by that token always forbid requiring him to choose. The threshold question is whether compelling the election impairs to an appreciable extent

silence against the defendant's substantial interest in the enforcement of the policies underlying the fifth amendment, which favor an accusatorial system in which the state must shoulder the entire load. Arenella, supra, note 85, at 53-54 n.118; see also Bradley, Griffin v. California: Still Viable After All These Years, 79 Mich. L. REv. 1290, 1292-94 (1981) (Griffin justified by irrationality of the California inference that the reason a defendant will choose not to take the stand is because of his guilt). Another finds Griffin supported under a due process rationale rather than by the fifth amendment. Ritchie, Compulsion That Violates the Fifth Amendment: The Burger Court's Definition, 61 MINN. L. REv. 383, 401 (1977).

98. Griffin, 380 U.S. at 614 . The Court was here quoting from the descriptions of the values behind the fifth amendment in Murphy v. Waterfront Comm'n, 378 U.S. 52, 55 (1964). One of those values is described as "our preference for an accusatorial rather than an inquisitorial system of criminal justice ...."Id.

99. 390 U.S. 377 (1968).

100. Id. at 393-94. Although Justice Harlan, in McGautha v. California, 402 U.S. 183, 211-12 (1971), questioned the validity of the opinion in Simmons, which he authored, the fifth amendment element of Simmons did not die so easily. In Lefkovitz v. Cunningham, 431 U.S. 801, 807-08 (1977), the Court relied explicitly on Simmons and its confiict-of-rights rationale.

101. 402 U.S. 183 (1971). 
any of the policies behind the rights involved. ${ }^{102}$

The Court then examined the impairment of the defendant's fifth amendment rights. Reiterating an important element of the Williams analysis, ${ }^{103}$ the Court held that when the "compulsion" to testify flows from the force of historical fact-the evidence available to the prosecution-it is not of the sort forbidden by the fifth amendment. ${ }^{104}$ The Court concluded that McGautha faced pressures analogous to those confronting any defendant who considers taking the stand at trial and, accordingly, found no violation of the fifth amendment. ${ }^{105}$

After McGautha, one might have expected the Court to recognize no violations of the fifth amendment outside the pristine inodel, especially when the pressures on the defendant to testify or remain silent flow primarily from the operation of the trial process. During the next term, however, in Brooks v. Tennessee, ${ }^{106}$ the Court struck down a statute that required the defendant to take the stand first in the defense case or not at all.

Because the statute created pressure on the defendant by forcing him to make a decision when uncertain whether "his own testiunony [would] be necessary or even helpful," 107 the Court concluded that the

102. Id. at 213 .

In Murphy v. Waterfront Comm'n, 378 U.S. 52 (1964), the Court described in some detail the policies behind the fifth amendment. While this description leaves the precise dimensions of these policies ambiguous, see Arenella, supra note 85 , at 37-38, it remains the most complete treatment provided by the Court to date:

[O]ur unwillingness to subject those suspected of crime to the cruel trilemma of selfaccusation, perjury or contempt; our preference for an accusatorial rather than an inquisitorial system of criminal justice; our fear that self-incriminating statements will be elicited by inhumane treatment and abuses; our sense of fair play which dictates " $a$ fair state-individual balance by requiring the government to leave the individual alone until good cause is shown for disturbing him and by requiring the government in its contest with the individual to shoulder the entire load"; our respect for the inviolability of the human personality and of the right of each individual "to a private enclave where he may lead a private life"; our distrust of self-deprecatory statements; and our realization that the privilege, while sometimes "a shelter to the guilty," is often "a protection to the innocent." Murphy, 378 U.S. at 55 (citations and footnotes omitted).

In addition, in Garner v. United States, 424 U.S. 648, 655-56 (1976), the Court identified "the fundamental purpose of the Fifth Amendment" as "the preservation of an adversary system of criminal justice," which is "undermined when a government deliberately seeks to avoid the burdens of independent investigation by compelling self-incriminating disclosures." The Court thus emphasized the central importance of the fifth amendment in preserving that element of the adversary system that prohibits the government from compelling disclosures from the defendant that it uses directly to secure his conviction.

103. Williams v. Florida, 399 U.S. 78, 84-85 (1970).

104. McGautha, v. United States, 402 U.S. 183, 215-16 (1971).

In Williams, the Court concluded that the alibi notice mle involves pressures "of the same nature as those that would induce [the defendant] to call alibi witnesses at the trial." Nothing in the rule "added to the legitimate pressures" to eall alibi witnesses. 399 U.S. at 85.

105. McGautha, 402 U.S. at 217.

106. 406 U.S. 605 (1972).

107. Id. at 610 . 
rule might well cause defendants to remain silent or to testify who would do otherwise in its absence. While acknowledging the state's interest in preventing the defendant from coloring his testimony once he heard the testimony of his other witnesses, the Court found that interest insufficient to override the defendant's right to remam silent. ${ }^{108}$ The Court declared the statute unconstitutional finding that it restricted Brooks's decision whether to reinam silent, burdened the exercise of his fifth amendment right, and made its exercise costly. ${ }^{109}$

While Brooks uses a balancing test for determining when a burden on the exercise of the defendant's rights is impermissible, the standards for finding compulsion are far froin clear. ${ }^{110}$ Subsequent cases, however, provide some guidance. For example, in Jenkins $v$. Anderson, ${ }^{111}$ the Court upheld the impeachment of a criminal defendant with his prearrest silence, again einploying a fifth amendment balancing test. The Court recognized that the practice may discourage or burden the exercise of the right to remain silent, ${ }^{112}$ but found that danger outweighed by the state's interest in enhancing the reliability of the trial process. ${ }^{113}$

McGautha and Jenkins make clear that the second model of compulsion requires a balancing between fifth amendment policies and the legitimacy of the state's infringement upon thein. For the challenged practice to survive, its benefit must outweigh the extent of its impairnent of the policies behind the fifth amendinent. ${ }^{114}$ The results in Griffin and Brooks are explained by the relative insubstantiality of the state's interest in the practices at issue and the centrality of the fifth amendment values adversely affected. ${ }^{115}$

108. Id. at 611 .

109. Id. at 610-11. The Court's approach in Brooks is closer to the Griffin approach, that any burden upon the fifth amendment is invalid, than to the explicit balancing of McGautha.

110. See Arenella, supra note 85, at 36-38 ("balancing without scales"); Note, Resolving Tensions Between Constitutional Rights: Use Immunity in Concurrent or Related Proceedings, 76 CoLuM. L. REv. 674, 687 (1976) [hereinafter Columbia Note] ("broad, unfocused balancing"); Note, Revocation of Conditional Liberty for the Commission of a Crime: Double Jeopardy and SelfIncrimination Limitations, 74 MrCH. L. REv. 525, 547 n.103 (1976) ("no clear line between permissible and impermissible consequences ... of invoking the privilege"); Note, The Due Process Need for Postponement or Use Immunity in Probation Revocation Hearings Based on Criminal Charges, 68 MiNN. L. REv. 1077, 1080 n.13 (1984) ("remains unclear exactly what constitutes an impermissible penalty") [hereinafter Minnesota Note].

111. 447 U.S. 231 (1980).

112. Id.

113. Id. at 238. ("Once a defendant decides to testify, '[ $t]$ he interests of the other party and regard for the function of courts of justice to ascertain the truth become relevant, and prevail in the balance of consideratiou determining the scope and limits of the privilege against selfincrimination." ") (quoting Brown v. United States, 356 U.S. 148, 156 (1958)).

114. McGautha v. United States, 402 U.S. 183, $215-16$ (1971); Jenkins v. Anderson, 447 U.S. 231, 238 (1980) (citing Chaffin v. Stynchcombe, 412 U.S. 17, 32 \& n.20 (1973)).

115. In Griffin the value at stake was the impermissibility of the court's creating evidence from the defendant's silence. 380 U.S. at 614-15; see also Carter v. Kentucky, 450 U.S. 288, 295, 301 
These decisions also indicate that the Court will independently assess the overall importance of the state interest involved and whether the interest can be attained only by inpairing the right at issue. ${ }^{116}$ Moreover, the Court will examine the state's underlying purpose in adopting the practice in question. If the fifth amendment right is burdened intentionally in an effort to discourage or penalize its exercise, the constitutionality of the practice is highly unlikely. ${ }^{117}$ Conversely, if the burden upon the right is only an incidental result of an otherwise legitinate practice, its validity is supported. ${ }^{118}$

In summary, under the second model of coinpulsion, the Court balances the defendant's interests in exercising his fifth amendment rights freely against the state's interest in, and need for, the challenged practice. On one side of the balance, the Court will place:

1. The importance of the policy behind the right which is impaired; and

2. The extent to which the right is impaired.

These factors will be weighed against:

(1981). In Brooks, it was the right of the defendant not to take the stand-a right at the heart of the privilege against self-incrimination-at a moment prescribed by the state, Brooks, 406 U.S. at 611 12, see infra notes 192 \& 194, coupled perhaps with the defendant's traditional right under our adversary system to control the timing of his testimony. Westen, supra note 83 , at $975-85$.

116. The plea bargaining process, which the Court has recognized as a "legitimate," indeed "an 'essential' and 'desirable" 'component of the administration of justice" " will inevitably discourage the exercise of rights; but this effect must be approved if plea bargaining is to be permitted. Chaffin v. Stynchcombe, 412 U.S. 17, 31 \& n.18 (1973) (quoting Santobello v. New York, 404 U.S. 257, 260-61 (1971)); see also Corbitt v. New Jersey, 439 U.S. 212, 218-23 (1978) (pressure to waive jury trial in exchange for lower maximum sentence permissible).

117. In Baxter v. Palmigiano, 425 U.S. 308 (1976), the Court suggested that the purpose of a state practice may be critical to validity when its impact is uncertain: "This [practice] does not smack of an invalid attempt by the State to compel testimony without granting immunity or to penalize the exercise of the privilege." Id. at 318; see also Lefkowitz v. Cunningham, 431 U.S. 801, 808 (1977) (rejecting "notion that citizens may be forced to incriminate themselves because it serves a governmental need").

118. In Chaffin v. Stynchcombe, 412 U.S. 17 (1973), the Court found that jury sentencing was used by the state for a legitimate purpose and was not merely a means for discouraging or penalizing the assertion of protected rights. It described the burden-a potentially higher sentence after retrial-as similar to the burden at issue in McGautha: the "incidental consequence" of a valid state practice. Chaffin, 412 U.S. at 31-32 \& n.20.

Issues similar to those in McGautha have been frequently raised in cases challenging a state's right to hold probation or parole revocation hearings prior to resolution of pending criminal charges forming the basis of the alleged violation of conditional release. Two of these cases, Ryan $v$. Montana, 580 F.2d 988, 991 (9th Cir. 1978), cert. denied, 440 U.S. 977 (1979) and Flint v. Mullen, 499 F.2d 100, 104 (1st Cir.), cert. denied, 419 U.S. 1026 (1974), focused upon the state's neutral purpose in holding the revocation proceedings promptly. Both courts contrasted this situation to one in which the state's explicit purpose is to gather incriminating evidence from the defendant. There, any penalty upon the defendant for violating the state's rule would directly burden the exercise of the right. Both courts stated that, if the state had instituted revocation proceedings first for the purpose of obtaining incriminating information from the defendant, the practice would have been unconstitutional. 
1. The overall importance of the state's practice to the administration of justice;

2. The underlying purpose of the state in promulgating the particular rule; ${ }^{119}$ and

3. The degree to which that purpose cannot be achieved without impairing the right. ${ }^{120}$

The method of determining whether a challenged practice violates the Constitution thus differs between the two compulsion models. The two analytic methods also differ $\mathrm{m}$ another important respect. Under the "pristine" model, a constitutional violation results from requiring the individual to make certain choices-silence, mcrimination, or perjurywhich the fifth amendment prohibits. Generally, how the challenged procedure affects a defendant's decision to testify or remain silent is irrelevant. The practice is mvahd because it forces this choice, regardless of the defendant's actual decision. ${ }^{121}$

Under the second model of compulsion, a constitutional violation results ouly when the burdens imposed on the fifth amendment policies by the state practice outweigh the state's interest in that practice. A violation of the defendant's rights thus depends primarily upon the impact of the state's practice, not merely upon the fact that a choice is required. Consequently, the actual impact of the rule-the state's use of the statement against the defendant-is critical to a violation of the fifth amendment. Thus, evaluating whether the defendant's rights have actually been impaired during the course of litigation becomes complicated.

119. The key issue here is whether the rule is designed to serve a neutral purpose or to discourage and penalize assertion of the fifth amendment right. See supra notes 117 \& 118 .

120. Arguably, this second model is simply an aberration in the development of fifth amendment law. Only two cases, Griffin and Brooks (possibly a third, Simmons), involving fifth amendment violations can be explained in no other way than this second mode of analysis. Because of their small number, the cases in this category might be labeled aberrational or be limited to their facts.

Indeed, a limiting process began in Griffin. Justice Stewart dissented there because he concluded that a comment on defendant's silence did not constitute compulsion. See supra note 96. Later, in Lakeside v. Oregon, 435 U.S. 333, 339-41 (1978), he spoke for the majority in holding that no compulsion arose when the trial court instructed the jury, over defense objection, not to draw any inference from the defendant's silence. Justice Stevens argued in dissent that if Griffin was still the law the challenged instruction was constitutionally invalid. Id. at 345 . He noted that two of the justices in the Lakeside majority had dissented in Griffin and expressed doubt that "any Member of the Griffin majority would join today's opinion." Id. at $344-45$ \& n.3.

Alternatively, the Court may determine that the fifth amendment should protect only against the types of compulsion similar to those with historically based origins. Such a strict interpretivist approach to the fifth amendment-that is, one holding that only those practices specifically contemplated by the Framers of the amendment may be judicially forbidden-would not lead to the result I urge here. Compare R. Berger, Government By Judiciary (1977) with J. Ely, DEMOCRACY AND DisTRUST (1980). The Court, however, has not consistently followed such a strict interpretivist approach in its fifth amendment cases (as shown by the results reached in Griffin and Brooks and by the mode of analysis employed in McGautha).

121. See supra note 91 . 
Since a required choice does not automatically violate the privilege against self-incrimination, a reviewing court must often determine whether the defendant's choice was in fact affected by the threatened sanction or simply reflected his judgment concerning the best litigation strategy. Accurately assessing the subjective impact of the threatened sanction upon the defendant is an important, but rarely easy, determination. ${ }^{122}$

The Supreme Court's analysis of the compulsion issue in McGautha, Brooks, Jenkins, and other cases shows that practices that unjustiflably penahize the exercise of a defendant's constitutional rights may be invalid even when compulsion in a strict sense is absent. As we have seen, most discovery rules do not subject defendants to the "cruel trilemma." They use no direct, external compulsion. Therefore, the extent to which they unconstitutionally burden the exercise of a defendant's fifth amendment rights will rarely be immediately obvious. In the following Part, I will apply the balancing approach developed above to several hypothetical discovery rules, some inspired by existing state rules. With this analysis, I will demonstrate that in cases in which the defendant's disclosures may be used to incriminate him, the fifth amendment is violated and mandates invalidation of that discovery practice.

122. In Chaffin v. Stynchcombe, 412 U.S. 17 (1973), the Court observed that the petitioner, who had in fact appealed his conviction, obviously had not been deterred from taking an appeal by the possibility of receiving a greater sentence from the jury after retrial. The Court expressed doubt "that the 'chill factor' will often be a deterrent of any significance," $i d$. at 33, and could not agree with the petitioner "that such speculative prospects interfere with the right to make a free choice whether to appeal." Id. at 35 . Since courts will rarely be able to determine the actual impact of any "burden" on the exercise of a defendant's constitutional rights, they must, generally, either speculate or deny relief because of an madequate showing of prejudice.

In some situations a rule's impact is clearer when separated from the defendant's strategic judgments. For example, contrast the state's unitary trial procedure in McGautha with another state's bifurcated proceedings. In the unitary proceedings, the requirement that the defendant's testimony be available for both guilt and punishment presents a difficult strategic decision. To obtain the benefits of having his testimony considered by the jury on the issue of punishment, the defendant must comply with the state's procedural rules which impose substantial, though incidental, costs.

In bifurcated proceedings, the same requirement would present very different issues. The defendant's decision to testify at the gnilt phase, when he wishes only to present testimony on punishment, could hardly be attribnted to a tough strategic decision. It could only be a condition on the right to testify. It is either a justifiable burden on testimony, or it is constitutionally invalid. See Minnesota Note, supra note 110, at 1086-88 (separate revocation hearing subject to discretionary scheduling by the state distinguishes such proceedings from unitary trial in McGautha); Columbia Note, supra note 110, at 709 (where state uses separate revocation proceedings, difficult choice facing defendant not inherent in adversary system, and tension between rights to remain silent and to testify "exerted not by the state's evidence but by its choice of procedure"). 
III

\section{The Fifth Amendment ApPlied to Prosecutorial DISCOVERY}

Though all discovery rules certainly do not violate defendants' fifth ainendment interests, those rules that require the defendant to make a statement or to provide information that the state may use to prove his guilt ${ }^{123}$ may significantly affect his fifth amendment rights. Yet, as shown above, the Supreine Court's decision in Williams v. Florida approved a discovery practice that required the defendant to choose between notifying the prosecution of his defense in advance of trial and foregoing the defense altogether.

Does Williams mean that the coercive force of the defendant's desire to retain the right to present evidence at trial alone does not constitute compulsion under the fifth amendment? Stated differently, does Williams hold that all pretrial discovery rules requiring the defendant to provide information that he intends to offer at trial are valid under the fifth amendinent-no inatter how mcriminating-provided the only sanction is exclusion at trial of the undisclosed information? ${ }^{124}$

I will test the limits of the Williams holding by applying the second

123. For a discussion of the testimonial aspects of discovery, see infra notes 161-68 and accompanying text.

124. The Court's conclusion in Williams that the alibi was not compelled has two possible meanings. The first meaning is that the defendant was not compelled because he would have taken the same action in the absence of the rule. We know this is true because at any time prior to introducing the alibi he could have abandoned it without adverse consequence. Since the state had not used his disclosures in its case, he suffered no harm directly resulting from discovery as opposed to his own decision to present the defense. Under this view, the extent of compulsion is irrelevant since a witness cannot be unconstitutionally compelled to take actions he would take freely absent the compulsion.

State v. Nelson, 14 Wash. App. 658, 545 P.2d 36 (1975) exemplifies the first interpretation. The defendants were ordered under threat of contempt to reveal prior to trial the nature of the defense they intended to present, together with the identity of their witnesses. When they refused to comply, they were jailed for contempt. The sanction obviously constituted direct compulsion. The appellate court, however, upheld the trial court's action. Id. at 667,545 P.2d at 41 . It applied the Williams rationale, holding the defendants' fifth amendment rights were not violated since the rule only accelerated the disclosure of information that they ultimately would have revealed; the court ignored any significance in the nature of the compulsion employed. Cf. South Dakota v. Neville, 459 U.S. 553 (1983) (admitting into evidence defendant's refusal to take breathalizer test does not violate privilege against self-incrimination since he has no fifth amendment right to refuse the examination).

The second possible meaning is that the coercive force presented by discovery is simply insufficient to violate the fifth amendment. Under this rationale, preclusion of the testimony, or any lesser sanction, is permissible but a threat of contempt is improper. Under this approach, Nelson would have been wrongly decided.

In some instances these meanings operate with a perfect overlap; there will be no need or occasion to separate them. As developed below, resolution of the questions of prosecutorial use, incrimination, and uncertainty determine whether the two meanings of compulsion are separated. One rcason that Williams decides so little is that, under its facts, these two possible meanings of compulsion remain perfectly intertwined. 
model of compulsion to a series of hypothetical discovery rules and illustrations that present the major fifth amendment issues raised by prosecutorial discovery. In the first hypothetical, I examine a discovery rule that requires the defendant to provide a discovery deposition as a condition of his right to testify at trial. I assume in this hypothetical that the defendant is not faced with the pressures flowing from uncertainty; he knows the strengths and weaknesses of the prosecutor's case and that his deposition will be used in the prosecutor's case-in-chief. By eliminating the element of uncertainty, I highlight in this hypothetical the critical importance of the state's use of the defendant's disclosures to the constitutionality of prosecutorial discovery. I deinonstrate that, under the second inodel of compulsion, such a rule would be invalid. In support of this conclusion I refer to analogous cases concerning discovery rules and the insarnty defense; courts have recognized that the potential for incrimination in discovery of the insanty defense requires fifth alnendment protections even when there is no coinpulsion in its pristine form.

In the second hypothetical, I examine typical discovery rules that require disclosure of defenses, witnesses, and witnesses' statements. As in the first hypothetical, I have eliminated the elenent of uncertainty; the defendant is fully aware of the potential for incrimination in his disclosures. The analysis of these rules focuses on the testimonial and potentially imcriminating nature of the defendant's responses, and again leads to the conclusion that such practices unconstitutionally penalize the exercise of the defendant's fifth anendment rights.

The third hypothetical focuses on the factual situation at issue in the Williams case. As in the second hypothetical, I examine typical discovery rules requiring pretrial disclosure of defenses and witnesses. In this case, however, I have included the element of uncertainty. The defendant is unsure of the consequences of his disclosure, both in terms of its potential to incriminate him and the extent to which it will lead to the discovery of other information that might strengtlien the state's case. This hypothetical deinonstrates that such uncertainty coinplicates the fifth ainendment analysis, as illustrated by imagining the facts of the Williams case litigated in a procedural context different from that presented to the Supreme Court. The hypothetical shows that it is the absence of potential for incrimination in the typical notice of alibi that justifies the discovery rule at issue in the Williams case. Thus, I conclude that where the defendant refuses to provide the required disclosures because he reasonably believes that his response will incriminate him, preclusion of his testimony will unconstitutionally burden his fiftl amendment right.

In the fourth hypothetical, I examine a rule that requires the defendant to give a pretrial deposition if he intends to testify, but protects the 
defendant against use of the deposition in the prosecutor's case-in-chief. This hypothetical focuses examination on the validity of impeaching the defendant with discovery disclosures. I conclude that even this limited use of discovery disclosures inay unjustifiably impair the defendant's fifth amendinent interests. Impeachment use should be permitted only when the defendant provides willfully false information or when his conduct places the state in a position such that it cannot adequately prepare to meet the defense at trial. I complete the discussion of impeachment use of discovery by examining specific state discovery practices regulating the use of discovery information for impeachment purposes.

\section{A. Hypothetical Case One: A Fully Usable Pretrial Discovery Deposition with Uncertainty Eliminated}

Assume that a state has enacted a discovery rule requiring all witnesses intending to testify (prosecution witnesses, defense witnesses, and the defendant himself) to give pretrial depositions under oath and subject to cross-examination. The rule states that no judicial compulsion by way of contempt may be used as a sanction, but only witnesses who have provided a deposition may testify at trial. In addition, it provides that such stateinents may be used by the adversary for any purpose and exphicitly authorizes the state to use the defendant's deposition in its case-in-chief. ${ }^{125}$ Though the rule applies to all witnesses, my analysis treats only its apphication to the defendant.

Let us also assume that the pressures added by the uncertainty inherent in pretrial discovery are eliminated. The defendant knows, for example, that his deposition will tend to incrimmate him and that the state will use his deposition, if he gives one, in its case-in-chief. ${ }^{126}$

125. This hypothetical was inspired by an argument of Professor Westen. Westen, supra note 83.

Professor Westen compares the Court's ruling in Williams with its decision in Brooks v. Tennessee, 406 U.S. 605 (1972). In Brooks, see infra notes 191-94 and accompanying text, the Court held unconstitutional Tennessee's statute requiring the defendant to testify first in the defense case or have his testimony barred. Professor Westen argues that under the Court's rationale in Williams a modified version of the Tennessee rule would be constitutional. The new rule would require the defendant to disclose the substance of his testimony 10 days in advance of trial or be precluded from taking the witness stand. It would be constitutional "because the statute does nothing but 'accelerate' a decision that the defendant eventually will be compelled to make at trial." Westen, supra note 83, at 958 (footnote omitted); see also id. at 978.

Professor Westen does not state explicitly whether he believes that to satisfy Williams the statute must impose limits on the prosecutor's use of the pretrial statement, but his analysis of the critical elements of Williams indicates that he believes no restrictions would be required. He argues that the ability of the prosecutor to use the evidence in its case-in-chief is not a critical factor in the Williams rationale; indeed, he suggests that it would be constitutional to require the defendant to present his case before the state produced any evidence. Westen, supra note 83, at $948 \mathrm{n} .55,981$ n.198; see also infra note 194.

126. The state is virtually certain to use the deposition if, for example, its case will withstand a motion for judgment of acquittal but is very weak on a critical issue for which the deposition is very 
The potential effects of the rule are significant. A defendant who wishes to testify must provide a full statement of his proposed testimony im advance of the government's presentation of any evidence. His statement may be used to shore up a weak government case; it may enable the state to present an effective, coherent theory selectively utilizing the defendant's own words to fill im important gaps. ${ }^{127}$ Because the rule does not threaten the defendant with an external sanction, the only pressure on him to give the deposition stems from his desire to avoid the force of historical facts and to reduce his chances of conviction by testifying at trial.

Even though compulsion is not present in its pristine form, such a rule undemiably raises constitutional issues. First, the deposition constitutes testimonial evidence that the defendant would not have provided for independent, strategic reasons. Second, under the facts of the hypothetical, the deposition will not only provide no benefit to the defendant but will actually incriminate him. The rule forces the defendant to choose between incriminatimg himself, to avoid being penalized with exclusion of his testimony at trial, and exercising his fifth amendment right not to incriminate himself by remaining silent, in which case he will not be permitted to testify in his own defense.

Regardless of the defendant's choice, the rule arguably is unconstitutional since it "casts a heavy burden" on the defendant's fifth amendment right ${ }^{128}$ or "cuts down on the privilege by making its assertion costly." 129 Recognizing this burden only begins the analysis, however. ${ }^{130}$ The fifth amendment is violated only if the defendant's statement is compelled. That is, the practice is invalid only if it impairs fifth amendment policies more than it furthers independent, legitimate state interests.

\section{Constitutionally Impermissible Burdens Are Imposed by the Operation of This Hypothetical Rule}

Under the balancing approach described above, the hypothetical rule meets the level of constitutional "compulsion" under the fifth amendment by unjustifiably impairing the pohicies that lie at the heart of the privilege. On one side of the balance, the fifth amendment policy

\footnotetext{
incriminating. Assume also that the defendant facing this rule is certain of (1) the strength of the government's case, (2) the impact of his statement in aiding the state's case, and (3) the substantial value of his own testimony if presented in the defense case.

127. Indeed, when the uncertainty of an actual discovery situation is present, the deposition may even provide the evidence necessary for the state to make out a prima facie case and to withstand a motion for judgment of acquittal at the end of its case. Then, the effect of the rule would be profound.

128. Brooks v. Tennessee, 406 U.S. 605, 610 (1972).

129. Griffin v. California, 380 U.S. 609,614 (1965).

130. See, e.g., Ayer, supra note 96 , at 853-55.
} 
impaired is the defendant's interest in being free from direct self-incrimination. The defendant's disclosures are both testimonial and incriminating, and the use permitted under the rule is substantially prejudicial to the defendant. ${ }^{131}$ As the Supreme Court stated in Garner v. United States, ${ }^{132}$ the fundamental purpose of the fifth amendment is "undermined when a government dehberately seeks to avoid the burdens of independent investigation by compelling self-incrimmating disclosures."133

The other side of the balance fails to justify these impairments of fifth amendment policies. First, the legitimate interests in disclosure that traditionally justify discovery-the avoidance of unfair surprise and the efficient administration of justice-provide support that is both practically and theoretically insufficient to outweigh the defendant's fifth ainendment imterests. Pretrial discovery promises to foster the states' interests by eliminating needless delays and unfair verdicts that result when the state is confronted with last-minute defense evidence. There is no solid evidence, however, that a rule requiring pretrial depositions is necessary to achieve this end. ${ }^{134}$ Moreover, even enhanced accuracy of

131. The Court has not stated its standard for judging when the fifth amendment right has been substantially impaired. Presumably, it would assess how clearly the defendant's conduct falls within the privilege as well as the extent and directness of the penalties.

In Jenkins v. Anderson, 447 U.S. 231 (1980), the Court acknowledged that permitting a defendant's trial testimony to be impeached with his prearrest silence might marginally discourage exercise of his right to remain silent before arrest. Nonetheless, the Court found the burden too insubstantial to violate the policies behind the right. The Court certainly would have reached a different result had the state prohibited the defendant's trial testimony because he maintained his prearrest silence. Similarly, in Baxter v. Palmigiano, 425 U.S. 308 (1976), the Court held that adverse inference upon silence of a defendant in a noncriminal prison disciplinary proceeding was valid because the sanction upon the petitioner's silence was only one factor in determining whether disciplinary action would be imposed.

132. 424 U.S. 648 (1976). See supra note 102.

133. Id. at $655-56$.

134. Only empirical evidence can show whether discovery against the defense has had a meaningful impact on either of these concerns. Unfortunately, no studies on the subject have been done. Even if such studies were to show that prosecutorial discovery results in a higher percentage of convictions, that fact alone would not prove that discovery eliminated "unfair surprise." Instead, prosecutorial discovery may deter vigorous defense efforts or otherwise shift the balance of advantage in favor of the prosecution.

Based on appellate cases, it is unclear whether extensive criminal discovery aids in eliminating delays. The one apparent result of broader discovery is a greater volume of appellate litigation. States in the southeast provide a useful example. Florida has an extensive discovery system and substantial prosecutorial discovery. The ncarby states of Georgia, South Carolina, and North Carolina provide relatively little criminal discovery and virtually none against the criminal defendant. Florida has produced scores of reported cases challenging discovery procedures, and a large number of cases have been reversed because of trial court errors. See, e.g., Smith v. State, 372 So. 2d 86 (Fla. 1979) (conviction reversed where trial court did not conduct immediate hearing upon appropriateness of preclusion sanctions for defense discovery violation). The body of appellate litigation in the other three states is far smaller.

Certainly, one cannot judge whether the entire criminal trial system is working more efficiently or more fairly by the volume of appellate litigation on discovery. If, however, the appellate courts 
the fact-finding process cannot sustain a direct violation of the fifth amendment privilege and its policies. If it could, only fifth amendment violations that threaten the rehability of the imformation secured would be invalid, and that is certainly not consistent with settled fifth amendment doctrime. ${ }^{135}$

Second, the rule's purpose is immediately suspect. While the state's interest in avoiding unfair surprise is technically distinct from a purpose of encouraging waiver of fifth amendinent rights, the distinction is not always clear. Even with a carefully structured rule, the state's purpose is to know the defendant's case so to better secure his conviction. Under the best circumstances, this interest is not very different from requiring disclosure of a directly incriminating statement for the purpose of convicting the defendant. ${ }^{136}$ Since the hypothetical rule permits the prosecution to use the disclosures directly to incriminate, and thus to impair the policies belimd the privilege, any separate purpose loses all significance.

Furthermore, the rule serves no independent strategic purpose for the defendant; disclosure does not result indirectly from actions serving lis own self-interest as occurred in McGautha. ${ }^{137}$ He complies only because le inust in order to be able later to present evidence or testimony at trial. ${ }^{138}$ The rule requires the defendant to speak when, except for its

are spending considerable time and energy grappling with discovery issues, the trial courts must be similarly engaged. Whether efficiency has been enhanced is open to question.

135. The possibility that coercion or compulsion might produce unreliable statements has been a concern in the context of both the due process concept of involuntariness and the fifth amendment. Regardless of reliability, however, statements that are involuntary or compelled are constitutionally invalid. See, e.g., Bram v. United States, 168 U.S. 532 (1897); Miranda v. Arizona, 384 U.S. 436 (1966).

136. More than virtually any other type of procedural rule, the "separate" purpose of discovery-avoiding unfair surprise-tends to merge with the purpose forbidden by the fifth amendment-requiring disclosures helpful to convict the defendant. While the California Supreme Court is wrong as a matter of federal fifth amendment analysis, its basic position in In re Misener, 38 Cal. 3d 543, 698 P.2d 637, 213 Cal. Rptr. 569 (1985) is not. Compelling communications from the defendant to impeach him and thereby assist in convicting him is hardly distinguishable, in terms of the policies behind the privilege, from more directly incriminating disclosures.

137. The defendant in Williams also gained no litigative advantage from providing discovery. The discovery practice in Williams is constitutional, not because it served an independent interest of the defendant, but because it posed no reasonable threat of incrimination. See infra, text accompanying notes 195-210.

138. Under rules that grant the prosecution an independent right of discovery, the preclusion sanction for noncompliance is a pure form of coercion that by design burdens a defendant's right to remain silent. When the information that would be disclosed is incriminating, these sanctions approach the level of coercion of the cruel trilemma.

When a defendant receives some trial benefit for providing testimony or evidence that may incriminate him, he provides it to serve his strategic interest in that benefit. In such a circumstance, the defendant is not compelled by external, independent sanctions levied for the purpose of causing him to waive his right to remain silent.

In discovery, the defendant enjoys no benefit from disclosing the information. Admittedly, the sanction is not separate to the trial process and therefore is not a direct, external penalty for refusing to waive his right. See Baxter v. Palmigiano, 425 U.S. 308, 317-18 (1976). Nevertheless, the rule 
operation, he would remain silent. ${ }^{139}$

The only remaining issue is how critical the infringement upon the privilege is to achieving an important state interest. A first examination suggests that the state's interest in avoiding unfair surprise could be satisfied without using the defendant's statements in its case-in-chief. Apparently, then, the primary cost of the rule is urmecessary for the state to achieve its legitimate goal. ${ }^{140}$

In summary, the rule imposes a substantial burden on the exercise of a defendant's fifth amendment right, and the state's legitimate interests in the rule do not justify the imposition of that burden. ${ }^{141}$ Thus, whether the defendant declines to give the deposition and is barred from produc-

acts as a direct penalty in the sense that it requires him either to relinquish his right to remain silent or to suffer the penalty of being prohibited from later presentation of testimony or evidence. Thus, where the disclosure required by the rule is poteutially incriminating, either the defendant abandons his protections under the fifth amendment, or, solely because of the discovery rule, he is denied the right to produce evidence to defend against the charge. Since an unattenuated result of being prohibited from producing evidence may be the defendant's conviction and imprisonment, it is difficult to distinguish between the discovery sanction and the threat of contempt under the cruel trilemma.

139. A comparison of McGautha v. California, 402 U.S. 183 (1971) with Brooks v. Tennessee, 406 U.S. 605 (1972) supports the conclusion that the hypothetical rule is unconstitutional. In McGautha, the unitary trial procedure served a legitimate and independent purpose of efficient litigation. There is no indication that the procedure was designed to coerce waiver of fifth amendment rights or to deny the right to present mitigating evidence. In fact, rules pernitted the defendant to present evidence and arguments in mitigation through other means even when he did not testify. Moreover, the defendant's decision to remain silent or to testify served some independent strategic interest. In short, a unitary trial procedure produces pressures much more similar to those faced by a defendant choosing whether to testify at trial than does the hypothetical rule.

On the other hand, the requirement in Brooks that the defendant testify first in the defense case or not at all is virtually indistinguishable from the hypothetical rule on the key issues. Like the hypothetical rule, the Tennessee statute required either-incrimination or forfeiture of the right to testify, and compliance with the statute served no independent interest of the defendant.

140. Separating the state's use of evidence in its case-in-chief from use on rebuttal may prove very difficult. See infra notes 212-13 and accompanying text. Where the justification for the pretrial discovery is strong enough, as with the insanity defense, fifth amendment protections may simply be compromised by necessity. See infra text accompanying notes 214-21.

141. This balancing process shows why "conditional discovery" generally is constitutional. Under conditional discovery a defendant may discover certain categories of information from the government if he allows prosecutorial discovery of similar information. The defendant waives his fifth amendment right by requesting discovery from the government. United States v. Ryan, $448 \mathrm{~F}$. Supp. 810, 811 (S.D.N.Y.), aff'd mem., 594 F.2d 853 (2d Cir. 1978), cert. denied, 441 U.S. 944 (1979); see also NEB. REV. STAT. § 29-1916(2) (1985) (where defendant's request for conditional discovery is granted, "he shall be deemed to have waived his privilege of self-incrimination").

The distinction between conditional discovery and independent prosecutorial discovery of any information a defendant wishes to introduce at trial turns on the extent of the disadvantage which the defendant suffers in the two situations. It does not turn on any difference between surrendering a "constitutional right" rather than a "privilege." See Westen, supra note 94. But see Statements of Justice Douglas Opposing Submission of Proposed Federal Rules to Congress, 39 F.R.D. at 276, 27678 (1966). Independent discovery requires a defendant either to forfeit his fifth amendment right to remain silent or to relinquish his right to introduce evidence and present his own testimony. Conditional discovery, by contrast, requires a defendant either to relinquish his fifth amendment 
ing testimony at trial ${ }^{142}$ or gives the deposition and it is used against him in the state's case-in-chief, ${ }^{143}$ his fifth amendment rights have been vio-

right or to surrender only his ability to discover information that the state is otherwise not constitutionally required to reveal.

The independent prosecutorial discovery skews the individual-state balance in favor of the state by making the defendant choose between self-condemnation or a seriously weakened defense. Conditional discovery offers the defendant an advantage at the price of reciprocal disclosure. The adversarial balance remains unchanged, so the fifth amendment is unimpaired.

It bears emphasis that conditional discovery is constitutional solely under a traditional waiver theory. It must be "an intentional relinquishment or abandonment of a known right or privilege." Johnson v. Zerbst, 304 U.S. 458, 464 (1938). Discovery is not like plea bargaining, in which some coercive force is an "inevitable attribute" of the "system which tolerates and encourages the negotiation of pleas" and in which constitutional rights are necessarily limited. Chaffin v. Stynchcombe, 412 U.S. 17, 31 (1973); see also Bordenkircher v. Hayes, 434 U.S. 357, 363-64 (1978). In the discovery context, unless the defense has purposefully abused the system, there is no adequate justification for the courts to impose an adverse consequence upon defendant's conduct. See Garner v. United States, 424 U.S. 648, 654 n.9 (1976); United States v. Byers, 740 F.2d 1104, 1113 (D.C. Cir. 1984) (en banc). Thus, conditional discovery must satisfy either waiver principles or the same standards as independent prosecutorial discovery.

On a practical level, where any discovery request by the defense entitles the prosecutor to discovery of all defense information, the defendant's waiver will often not be knowing and intelligent. Furthermore, since the defense counsel may not know at the time of discovery what incrininating information later investigative efforts may nnearth, some defense discovery requests will not satisfy a waiver standard even at a theoretical level. See State v. Williams, 80 N.J. 472, 404 A.2d 34 (1979) (defense counsel's request for discovery considered not to have waived objection to prosecutorial discovery of damaging information later developed by defense). Since competent counsel would rarely request discovery when she knows of highly incriminating information that would then be rendered discoverable, traditional waiver standards will not be satisfied in marginal cases-the very cases in which independent discovery will run afoul of the constitution. Thus, both conditional discovery and independent prosecutorial discovery will often run afoul of the Constitution when the disclosure is truly incriminating, albeit for different reasons.

142. Professor Westen argues that where the defendant remains silent and is prohibited from testifying, his right to testify under the compulsory process clause of the sixth amendment is violated, rather than his fifth amendinent right against compulsory incrimination. Westen, The Compulsory Process Clause, 73 Mich. L. Rev. 71, 117-20 (1974).

Other commentators, who find the right to testify in the due process clause of the fifth amendinent, suggest that due process is violated by precluding his testimony under these circumstances. Clinton, The Right to Present a Defense: An Emergent Constitutional Guarantee in Criminal Trials, 9 IND. L. REV. 711, 793-95 (1976); Ritchie, supra note 97, at 404-06; cf. McGautha v. California, 402 U.S. 183, 211-12 (1971) (Justice Harlan characterizes Simmons as resting exclusively on violation of defendant's rights under fourth amendment to litigate colorable claim, independent of fifth amendinent.). See generally Bradley, Havens, Jenkins, and Salvucci, and the Defendant's "Right" to Testify, 18 AM. CRIM. L. Rev. 419, 420-23 (1981) (discussing history and constitutional basis for right to testify). While due process is concerned primarily with a fair balance between the defendant and the state, it does, to an extent, require that the balance in discovery be tipped toward the defendant and, like compulsory process, could be offended by exclusion of defense evidence. Wardius v. Oregon, 412 U.S. 470,475 n.9 (1973) ("Indeed, the State's inherent information gathering advantages suggest that if there is to be any imbalance in discovery rights it should work in the defendant's favor."); see also In re Winship, 397 U.S. 358, 364 (1970) (due process requires the state to bear the burden of proof beyond a reasonable doubt).

143. Professor Blumenson presents the novel argument that prosecutorial use of the defendant's statements in the state's case-in-chief violates a defendant's due process right "to defend by failure of government proof," rather than his fifth anendment right. Blumenson, supra note 33, at 125-26, $154-56$. 


\section{lated. ${ }^{144}$ As a result, the hypothetical rule is invalid. ${ }^{145}$ The analysis also demonstrates the general point that the state violates the fifth amend-}

144. A discovery rule may be invalid under the privilege against compulsory self-incrimination, compulsory process, and due process. The fifth amendment protection against self-incrimination remains the most appropriate from an analytical perspective, however, since it is directly concerned with preventing the prosecution from forcing the defendant to provide testimonial evidence useful to convict, and it provides the most effective protection to the defendant. The due process clause has been particularly unhelpful in discovery contexts.

The notice of alibi rule demonstrates the limited impact of due process on discovery rules. Under Federal Rules of Criminal Procedure 12.1, the government can demand defense disclosure of the names and addresses of its alibi witnesses. Reciprocally, the government must provide the names and addresses of its witnesses who would place the defendant at the scene of the crime and who would rebut his ahbi. Wardius v. Oregon, 412 U.S. 470, 475 (1973). But this restriction does little to insure that discovery will not be entirely a one-way strect favoring the prosecution. Because the prosecution alone controls the "trigger," this flow of imformation, while superficially reciprocal, will in fact be favorable to the government. The government never has to reveal information unless it determines that the net exchange will be to its advantage.

Defendants have unsuceessfully challenged the mequality of the rule on several occasions. United States v. Bouye, 688 F.2d 471 (7th Cir. 1982); United States v. Benton, 637 F.2d 1052, 105859 (5th Cir. 1981); United States v. Savage, 430 F. Supp. 1024, 1036 (M.D. Pa. 1977), aff'd mem., 566 F.2d 1170 (1977), cert. denied, 434 U.S. 1078 (1978). In Bouye, the court stated explicitly that the alibi notice rule "was designed to be a prosecution-triggered device for the primary benefit of the government . . . to avoid unfair surprise and delays at trial" (emphasis added). To permit the defendant to initiate discovery would allow him to thwart the congressional policy of protecting the names of government witnesses from disclosure, 688 F.2d at 475 , and nothing in the due process clause prevented this one-way advantage. Id. at $473-475$.

145. This hypothetical might be challenged on several grounds. First, one might argue that it is unrealistic because no defendant would decide before trial to introduce testimony he knew to be incriminating. It could happen, however, under some circumstances. For example, defense counsel often will admit substantial elements of the state's case in his opening statement for the purpose of appearing honest with the jury. If the defense determines in a homicide case that the state's case on identity will withstand a motion for judgment of acquittal, counsel may acknowledge that the defendant did kill but assert that he did so in self-defense. Discovery would be provided under that fact pattern.

Second, one might disagree with my result-that the rule is unconstitutional-since the defendant would present his testimony in any event. Under my assumptions, the defendant must present the testimony when the defense case begins and, because the state's case otherwise is sufficient to withstand a motion for judgment of acquittal, he would certainly do so. This hypothetical of total certainty focuses the issue on why the rule violates the fifth amendment even when the defendant would produce testimony anyway. The question is, how is the defendant harmed?

The answer to this question turns on the fundamental meaning of the fifth amendment: what practices it prohibits, and what policies it reflects and protects. Historically, the privilege protected against the suspect being placed under oath, without formal accusation, for the purpose of extracting testimonial assertions from him that would be used to prove his guilt. See generally L. LEvY, supra note 89; 8 J. WIGMORE, EVIDENCE $§ 2250$ (McNaughton rev. 1961). The privilege also clearly grew out of and protects a group of values, L. LEVY, supra note 89, at 331-332, 430-32, relating to the requirement that the government "shoulder the entire load" rather than require proof from the mouth of the defendant, Murphy v. Waterfront Comm'n, 378 U.S. 52, 55 (1964), and the central proposition that our "system of criminal prosecution is accusatorial, not inquisitorial, and that the fifth amendment privilege is its essential mainstay." Malloy v. Hogan, 378 U.S. 1, 7 (1964).

My hypothetical invokes these values central to the fffth amendment. The evidence at issue is the testimony of the defendant that will be used to establish his guilt and is produced under threat of forfeiture of his right to testify. See M. BERGER, supra note 85, at 96 ("The use of [discovery] ... to 
ment when, under threat of precluding his testimony, it requires a defendant to make a statement in discovery that it uses directly to prove his guilt. Direct use of a defendant's statement obtained through discovery is itself sufficient to violate the fifth amendment.

\section{The Insanity Defense-Application of Fifth Amendment Principles to Discovery That Incriminates}

My conclusion that the hypothetical rule examined above is unconstitutional can be tested by reference to cases challenging discovery of the insanity defense. The insamity defense, like the deposition described above, manifests obvious potential for incrimination. Perhaps as a result, courts have examined fifth amendment issues with care. Though profound prosecutorial need for discovery has produced a "necessity" exception to the privilege against self-incrimination, courts consistently have held that the defendant's incriminating disclosures cannot be used by the state in its case-in-chief to prove his guilt.

In federal criminal prosecutions before $1984,{ }^{146}$ if the defendant raised the issue of insanity and introduced some evidence to support his defense, the government bore the burden of proving beyond a reasonable doubt that he was sane at the time of the crime. ${ }^{147}$ Rule 12.2 of the Federal Rules of Criminal Procedure provides: (1) the defendant must give notice to the prosecution if he intends to rely upon a defense of insanity, (2) the court may order the defendant to submit to a psychiatric examination at the request of the government, and (3) the court may

prove guilt as opposed to rebutting a so-called affirmative defense is the essence of compelled selfincrimination.").

Furthermore, whether or not the rule influences the defendant's choice, it has an important impact on how the evidence is used against him. When the defendant reveals incriminating information on his own, such as through the opening statement, he does so in a way to help his case. If the prosecutor may require the disclosure and introduce it in the first instance, the defendant loses his advantage. The statemient may be truncated; its timing will be such as to fit within the state's framework of proof; generally the presentation will not enhance the exculpatory value to the defendant. Professor Westen argues that under Brooks v. Tennessee, 406 U.S. 605 (1972), the defendant has a right to control the timing of his testimony to "be most effective." Westen, supra note 83, at 975; see also infra note 194. If Westen's contention is true, the defendant should, $a$ fortiori, have the right to control who presents his testimony, and when. Professor Westen argues that this right is distinct from the fifth amendment. Id. I contend it is simply one of the values protected by the fifth amendment prohibition against the state requiring the defendant to produce evidence that incriminates him. In my hypothetical, discovery permits the state to use the defendant's testimony in a way detrimental to his interests.

My total-certainty hypothetical notwithstanding, most discovery rules create great uncertainty, exacerbating their violation of the fifth amendment. Accordingly, even if I am wrong in concluding this hypothetical violates the fifth amendment, when the uncertainty of real world discovery is added, the fifth amendment is certainly violated.

146. The Comprehensive Crime Control Act of 1984, 18 U.S.C. 20(b) (Supp. 1985), changed the law. It places the burden on the defendant to prove by clear and convincing evidence that he was insane.

147. Davis v. United States, 160 U.S. 469 (1895). 
exclude the testimony of defense experts for the defendant's failure to give notice of an insanity defense or to subinit to an examination by governinent psychiatrists. ${ }^{148}$

Many of the issues raised by discovery of the insanity defense are indistinguishable froni those raised by the hypothetical discovery rule described above. The insanity defense rule authorizes the judge to order the defendant to subınit to an examination by government psychiatrists. The penalty for violating the order is not contenpt but preclusion of favorable psychiatric testimony. Also, because a defendant will generally discuss the details of the crime and often admit factual guilt in his interview with the psychiatrists, the government's use of the testimony in its case-in-chief would incriminate the defendant. Thus, discovery in this context, as with the hypothetical rule discussed above, is incriminating as well as testimonial. ${ }^{149}$ Generally, however, it is no more compelled than under the notice of ahibi rule at issue in Williams.

Courts examining prosecutorial discovery of the insanity defense have addressed two major fifth aniendment issues. The first and most frequently examined issue is whether use of the government's examination to rebut the defendant's insanity defense violates the fifth amendment privilege. When the government has the burden of proving sanity if the defendant raises the issue, even using his statements to prove sanity incriminates the defendant. ${ }^{150}$ Nevertheless, the lower federal courts consistently have held that such use does not violate the fifth amendment. ${ }^{151}$

148. The rule also prohibits the prosecution from using directly or indirectly a defendant's statements to a psychiatric expert made under the rule "except on an issue respecting mental condition on which the defendant has introduced testimony." FED. R. CRIM. P. 12.2(c).

149. Estelle v. Smith, 451 U.S. 454, 463-65 (1981) (holding that statements given to a psychiatrist are "testimonial" when "the substance of [defendant's] disclosures" is used as evidence against him).

150. See, e.g., Thornton v. Corcoran, 407 F.2d 695, $699-700$ (D.C. Cir. 1969) ("Nothing in the background or application of the [federal pretrial examination] statute ... suggests any reason but long practice to except statements relating to sanity from the protection of the Fifth Amendment.").

151. See, e.g., United States v. Madrid, 673 F.2d 1114, 1121 (10th Cir.), cert. denied, 459 U.S. 843 (1982) (where defendant gives notice of insanity defense and introduces substantial psychiatric evidence to prove incompetence at the time crime was committed, a psychiatrist "may testify against the defendant concerning the competency issue without violation of the Fifth Amendment privilege"); United States v. Reifsteck, 535 F.2d 1030, 1033-34 (8th Cir. 1976) (where psychiatrists do not testify regarding incriminating statements made by defendant but only provide their evaluations of her mental state when the crime occurred, such testimony does not violate defendant's fifth amendment rights); United States v. Cohen, 530 F.2d 43, 46-48 (5th Cir.), cert. denied, 429 U.S. 855 (1976) (using a balancing test to measure state's ability to counter defendant's proof regarding sanity against defendant's fifth amendment rights); United States v. Handy, 454 F.2d 885, 888-89 (9th Cir. 1971), cert. denied, 409 U.S. 846 (1972) (court order appointing psychiatrist does not violate fifth amendment where statute authorizing such appointments forbids using statements made by defendant regarding guilt and where order "did not compel 'communications' or 'testimony" " about the defendant's guilt); United States v. Bohle, 445 F.2d 54, 66-67 (7th Cir. 1971) (psychiatric evaluation does not violate defendant's fifth amendment rights where testimony based on the 
In United States v. Byers, ${ }^{152}$ the District of Columbia Circuit court, sitting en banc, examined the issue im some detail. Judge Scalia, writing for the majority, rejected, as "at best a fiction,"153 the theory that the defendant waives any fifth amendment objection by introducing expert testimony. He stated that a defendant's decision to submit to an examination by a government psychiatrist is not voluntary, as traditional waiver theory requires, smce the defendant must do so if he is to present any evidence. ${ }^{154}$

Judge Scalia also examined-and rejected-other theories various courts had used to justify use of the information. He found that despite their stated reasoning, those decisions implicitly relied on principles of necessity and fairness:

[Those courts] have denied the Fifth Amendment claim primarily because of the unreasonable and debilitating effect it would have upon society's conduct of a fair inquiry into the defendant's culpability.... We agree with this concern, and are content to rely upon it alone as the basis for our rejection of the Fifth Amendment claim. ${ }^{155}$

Byers thus holds that when the demands of litigative fairness are extrene enough, the fifth amendment right, which is designed to protect the individual against the state's ability to compel testimony from hin for his own condemnation, is overridden.

The Byers court did not exphicitly address the critical second issue raised by the hypothetical rule: the use to which discovery disclosures may be put. To say that a strong claim of necessity by the state will sometimes justify compelling an incriminating response from a defendant for rebuttal purposes is not to say that the state is similarly justified in using the defendant's disclosures to establish the defendant's factual guilt. Courts consistently have held that the evidence obtained through a psychiatric examination may not be used for the purpose of proving that

examination speaks only to defendant's mental state and not to his guilt); United States v. Weiser, 428 F.2d 932, 936 (2d Cir. 1969), cert. denied, 402 U.S. 949 (1971) (defendant is estopped from claiming a violation of his fifth amendment rights where prosecution introduces psychiatric evidence regarding defendant's mental state, but not his guilt, to counter defendant's showing on his mental condition); United States v. Albright, 388 F.2d 719, 723 (4th Cir. 1968) (psychiatric examination does not violate defendant's fifth amendment rights when the examination's results are used to determine defendant's mental condition, not his guilt).

152. 740 F.2d 1104 (D.C. Cir. 1984) (en banc).

153. Id. at 1113 .

154. Id.

155. Id.

In United States v. Albright, 388 F.2d 719, 724 (4th Cir. 1968), the Fourth Circuit articulated the same necessity argument as follows: "[I]f the government is required to shoulder the entire load,' it cannot be denied access to the only reliable means of ascertaining the truth concerning a defendant's sanity." The court ruled that the government accordingly must have access to the defendant's personal thoughts through a psychiatric interview. See also Estelle v. Smith, 451 U.S. 454, 465-66 (1981) (noting with apparent approval requirement imposed by several of the federal circuits that defendant submit to such psychiatric examination when asserting insanity defense). 
the defendant committed the charged crime. Such use would violate either the fifth amendment, ${ }^{156}$ the due process clause, ${ }^{157}$ or both. ${ }^{158}$ The same courts also have held that the prosecution violates the defendant's rights when it uses the evidence to establish factual guilt whether or not the defendant was compelled to submit to the mental exammation. ${ }^{159}$

156. Noggle v. Marshall, 706 F.2d 1408, 1416 (6th Cir.) (admitting defendant's inculpatory statements during psychiatric examination to prove factual guilt "would make the privilege against self-incrimination illusory"), cert. denied, 464 U.S. 1010 (1983); Gibson v. Zahradnick, 581 F.2d 75, 78-81 (4th $\mathrm{Cir}$.) (fifth amendment prohibits use of incriminating statements made during a psychiatric examination to prove factual guilt whether defendant or prosecutor requested the examination and whether conducted for the purpose of determining competency or sanity), cert. denied, 439 U.S. 996 (1978); United States v. Bohle, 445 F.2d 54, 66-67 (7th Cir. 1971) (use of testimony from compelled examination to prove guilt improper (apparently) under fifth amendment).

157. Collins v. Auger, 428 F. Supp. 1079, 1082-83 (S.D. Iowa 1977) (due process prohibits the use of defendant's statements to psychiatrist as part of prosecution's case to establish guilt, regardless of who requests the examination and whether it is for insamity or competency determinations), rev'd and remanded on other grounds, 577 F.2d 1107 (8th Cir. 1978), cert. denied, 439 U.S. 1133 (1979); State v. Evans, 104 Ariz. 434, 436, 454 P.2d 976, 978 (1969) (en banc) (due process prohibits use to establish guilt); People v. Finn, 64 A.D.2d 526, 526, 406 N.Y.S.2d 800, 801 (1978) (due process prohibits use of defendant's statements to establish guilt, whoever requests the examination).

158. State v. Craney, 347 N.W.2d 668, 673-74 (Iowa) (fifth amendinent and due process violated by state use of defendant's statements to his own psychologist on issue of guilt, but harmless given the overwhelming state case on this issue), cert. denied, 469 U.S. 884 (1984).

159. Gibson v. Zahradnick, Collins v. Auger, State v. Craney, People v. Finn. See supra notes 156-58.

The Supreme Court might well hold that these and other cases are wrongly decided on the fifth amendment issue where the defendant is subjected to no external compulsion to undergo the examination. Estelle v. Smith, 451 U.S. 454 (1981) may even be read to suggest disagreement with the rationale of these cases. In that case the Court reversed the Fifth Circuit because Smith had not been warned of his Miranda rights and "did not voluntarily consent to the pretrial psychiatric examination after being informed of his right to remain silent and the possible use of his statements ..." 451 U.S. at 468 . This description of the violation suggests that if he had voluntarily consented to the examination in order to obtain the benefits of the insanity defense, Smith would have had no fifth amendment protection. See Collins v. Auger, 428 F. Supp. 1079, 1083 (S.D. Iowa 1977) ("If the giving of a Miranda warning ... made the defendant's [statements] admissible, the defendant would be placed in a situation where he must sacrifice one Constitutional right to claim another."), rev'd and remanded on other grounds, 577 F.2d 1107 (8th Cir. 1978), cert. denied, 439 U.S. 1133 (1979). The more reasonable reading of Smith, however, is consistent with these cases. Under this interpretation, the Supreme Court approves a required psychiatric examination by the prosecution if the defendant raises an insanity defense, Smith, 451 U.S. at 465 , while recoguizing a type of limited use immunity when the defendant's refusal to waive his fifth amendment rights would thwart a legitimate state interest. Id. at 468.

Even if the Court disagreed with Gibson, Collins, Craney, and Finn, the resolution of the fifth amendment issue in the insanity area would not necessarily mean that the defendant could be required generally to forfeit either his fifth amendunent protection or his right to offer testimony. A defendant has no constitutional right to raise an insanity defense if his mens rea is proven. $C f$. Patterson v. New York, 432 U.S. 197, 205-06 (1977) (burden of proof on insanity may be placed on defendant); Rivera v. State, 351 A.2d 561, 562-63 (Del.) (state inay require defendant to prove mental illness by preponderance of evidence), appeal dismissed, 429 U.S. 877 (1976); Leland v. Oregon, 343 U.S. 790, 789-99 (1952) (state may require defendant to prove insanity beyond a reasonable doubt). The state would logically have somewhat more latitude in imposing conditions upon the exercise of that "optional" defense than it would have on the right of a defendant to testify and to introduce evidence. 
In summary, in the insanity context, as with the hypothetical rule, the defendant "voluntarily" provides incriminating testimony in order to raise his defense. In spite of Williams, however, under accepted doctrine the state violates the fifth amendment (even absent formal compulsion) if it uses the incriminating information to prove facts other than sanity. Courts' treatment of the constitutionality of discovery under the insanity defense suggests that fiftl amendinent analysis of discovery rules as well requires more than the narrow focus on coinpulsion employed in Williams, and that a broad reading of that holding is unjustified. The insamity cases suggest that it is the use of the pretrial disclosures, rather than their "voluntariness," that is crucial to the determination of the constitutionality of discovery rules.

Other concerns must also be addressed to complete the analysis of doctrimes applicable to prosecutorial discovery. The next hypothetical concentrates on another of these issues-the testimoirial quality of discovery disclosures.

\section{B. Hypothetical Case Two: Typical Discovery Rules with Uncertainty Eliminated}

For this analysis, assume the state requires the defendant personally ${ }^{160}$ to give notice of any defense he intends to use at trial together with the names and addresses of supporting witnesses, under threat of preclusion of all defenses and all witnesses, including his own testimony, not disclosed. In this liypothetical, like the first, the defendant has full knowledge of all consequences of his choice to provide discovery. While appearmg to change the nature of the problem dramatically, these modifications of the liypothetical only change the inajor issues if the defendant's response to the discovery request were considered not "testimomal." But, as will be demonstrated, the disclosures required under this hypothetical retain the essential testimonial quality of a deposition.

160. In Massachusetts and New Hampshire, for instance, an alibi notice must be signed by the defendant. MASS. R. CR1M. P. 14(b)(1)(A); N.H. SUPER. CT. R. 100. Other states permit either the defendant or counsel to sign the notice. See, e.g., ARIz. R. CRIM. P. 15.2(b); PA. R. CRIM. P. $305(C)(1)(a)$.

As a general rule of evidence, statements by counsel, as agent of the defendant, constitute evidentiary admissions by the defendant. As a result, counsel's response to a discovery rule may often be used as a statement by the defendant. See, e.g., United States v. McKeon, 738 F.2d 26, 30. 31 (2d Cir. 1984) (opening statement of counsel at prior trial inconsistent with subsequent opening statement constitutes admission that government may introduce to show consciousness of guilt); State v. Dault, 19 Wash. App. 709, 717-18, 578 P.2d 43, 48 (1978) (statements by attorney concerning nature of defense at pretrial hearing in presence of defendant were within scope of attorney's duties and therefore constituted admission); accord State v. Howell, 56 Or. App. 6, 11, 641 P.2d 37, 39 (1982) (pretrial defense disclosure signed by defense counsel may be used to impeach defendant's testimony at trial). 


\section{Testimonial Aspects of Discovery}

The defendant's response under this rule constitutes testimonial disclosure ${ }^{161}$ under two different theories. First, the response is testimonial if the state exploits its communicative content and uses it directly in evidence or derivatively to develop other evidence. Second, it may be testimonial if, under the "production doctrine" of Fisher v. United States, ${ }^{162}$ the defendant provides information $\mathrm{m}$ his response of which the state was ignorant.

Under the first theory, the testimonial nature of the response depends upon the state's intended use of the defendant's disclosures. ${ }^{163}$ For example, the state may use the required disclosures as an adnission or as an mconsistent statenient. Some states presently permit such use with a withdrawn alibi notice. The state may also use the disclosures derivatively to develop other admissible evidence that will aid it in convicting the defendant. When the state uses discovery for what it conveys about historical fact, ${ }^{164}$ no primcipled distimction exists between explicit statenients of the defendant and discovery disclosures of his defenses and witnesses.

Under the second theory, if the state uses discovery to learn about

161. In Schmerber v. California, 384 U.S. 757, 761 (1966), the Supreme Court held that the privilege against self-incrimination "protects an accused only from being compelled to testify against himself, or otherwise provide the State with evidence of a testimonial or communicative nature." While the Court itself did not explain how testimonial conduct differs from conduct constituting "real or physical evidence," the most widely accepted definition of testimonial conduct is "any activity performed for the purpose of communicating." MCCORM1CK ON EV1DENCE $§ 124$ at 302 (E. Cleary 3d ed. 1984).

162. 425 U.S. 391 (1976).

163. In Estelle v. Smith, 451 U.S. 454 (1981), the state argued that the defendant's statements during a psychiatric interview were real evidence. The Court rejected the argument because at trial the state had relied upon "the substance of [the defendant's] disclosures." Id. at 465 . Where the state uses the disclosure in a way that relies upon the defendant's "moral responsibility for truthtelling," the testimonial requirement has been satisfied. $8 \mathrm{~J}$. WIGMORE, EVIDENCE $\$ 2264$ at 379 (McNaughton rev. 1961) (emphasis in original); see also 2 C. Wright, FEDERAL PraCtice AND PROCEDURE $§ 256$ at 106-07 (1982); cf. Fisher, 425 U.S. at 411 (testimonial requirement not satisfied where government does not rely on defendant's "truthtelling").

164. In Williams, Justice White wrote, "It might also be argued that the 'testimonial" disclosures protected by the Fifth Amendment include only statements relating to the historical facts of the crime, not statements relating solely to what a defendant proposes to do at trial." Williams v. Florida, 399 U.S. 78, 86 n.17 (1970). His argument can best be understood by separating the backward-looking historical discovery information from forward-looking trial conduct information.

Justice White's construction of the concept of testimonial conduct is too restrictive, however. In terms of the defendant's intention to communicate information, a statement relating to trial conduct is clearly testimonial; in terms of prosecutorial use, the disclosure enables a narrowing of the prosecution's case to focus on the proffered defense. Thus, even the totally forward-looking aspect of the disclosure is testimonial. See supra note 81.

Nonetheless, statements of anticipated trial conduct may not be sufficiently incriminating to implicate the fifth amendment. $2 \mathrm{~W}$. LAFAVE \& J. IsRaEL, CRIMINAL Procedure $\$ 19.4$ at 520 (1984); Columbia Note, supra note 110, at 699 n.146. 
facts of which it would otherwise be ignorant, the disclosure is testimonial under Fisher's production doctrine. ${ }^{165}$ In Fisher, the Court identified three implicit commumications that may result from a response to a demand for information: (1) a concession that the document demanded exists; (2) an acknowledgment of possession or control of it; and (3) an implicit autlentication of the document. ${ }^{166}$ This discussion will focus on the first of these three commumications smce it is generally the only one at issue in the discovery context.

Under Fisher, for disclosure of preexisting imformation to come within the fifth amendment, the state must be unaware of the information that the defendant provides or of the other facts that may reasonably be obtained from it. In Fisher, for instance, the Court found no testimonial conduct when "[t]he existence and location of the papers [under subpoena] are a foregone conclusion and taxpayer adds little or nothing to the sum total of the Government's information by conceding that he in fact has the papers . . . The question is not of testimony but of surrender." "167

In other situations, however, the defendant's statement will be testimonial under Fisher. In a self-defense case, for instance, both of the fol-

165. See People ex rel. Bowman v. Woodward, 63 Ill. 2d 382, 349 N.E.2d 57, 60 (1976); Mosteller, Simplifying Subpoena Law: Taking the Fifth Amendment Seriously, 73 VA. L. REv. 1, 11 40 (1987) (analyzing testimonial and incriminating aspects of the act of producing documents and impact of foregone conclusion concept).

166. Fisher, 425 U.S. at 410.

167. Id. at 411 (quoting In re Harris, 221 U.S. 274, 279 (1911)).

By contrast, in United States v. Doe, 465 U.S. 605 (1984), the court of appeals found that the government did not know whether the documents subpoenaed existed, but rather drew "'broad. sweeping subpoenas ... to compensate for its lack of knowledge by requiring the [defendant] to become, in effect, the primary informant agaimst himself.' 'Id. at 613 n.12 (quoting Matter of Grand Jury Empanelled March 19, 1980, 680 F.2d 327, 335 (3d Cir. 1982)). Thus, under the facts of Doe, a response to the subpoena would be sufficiently testimonial to invoke the protections of the fifth amendment, as distinguished from Fisher where it had "only minimal testimonial value." Id. at 613; see also United States v. Fox, 721 F.2d 32, 38 (2d Cir. 1983).

In Doe, the Court ruled that the act of production could be immunized and that immunity need not extend to the contents of the document: "[T] he privilege in this case extends only to the act of production. Therefore, any grant of use immunity need only protect respondent from the self. incrimination that might accompany the act of producing his business records." 465 U.S. at 617 n.17.

Because of the limited nature of the defendant's "testimonial" act under the "production" theory, the state may call a witness (other than the defendant) who it learns through "legitimate" sources has relevant knowledge. In United States v. Nobles, 422 U.S. 225 (1975), the Court held that a defense witness could be compelled under court order to provide information previously obtained from a government witness. The Court relied on the fact that the fifth amendment privilege is personal to the defendant and that the disclosures were required of, and compulsion was directed toward, a defense witness. Id. at 234. Furthermore, the defense in Nobles had voluntarily disclosed both the existence of the witness and the document in question. Thus, the prosecution was not requiring the defendant to disclose the existence of incriminating facts of which the prosecution was ignorant. Once the defendant voluntarily made the disclosure, his witness could be compelled to produce the item at issue. 
lowing types of disclosures are testimonial for purposes of the fifth amendment: (1) a defendant's statenient in which he says that he committed the killing but did so in response to an attack by the decedent; and (2) a notification by the defendant that he will claim self-defense and that he will rely upon a witness whom he identifies and locates for the state, accompanied by the witness's statenient reciting that the defendant killed the decedent in response to an attack. ${ }^{168}$

Typical discovery rules, then, can and do elicit "testimonial" responses from the defendant. In my hypothetical, where the defendant's uncertamty has been eliminated, the responses will be incriminating as well; that is, the defendant knows not only that his response will inform the prosecution of facts of which it was ignorant but also that these facts will be used by the state to establish his guilt. This hypothetical illustrates the fact that where a class of information is not covered by the fifth amendment, the reason it is excluded is not because it fails to satisfy the testimonial requirenient but because the disclosure is insufficiently harmful to the defendant.

A number of specific types of discovery requirements might be mandated under the hypothetical rules.

\section{Discovery of the Nature of the Defense}

Some states require only that the defendant specify his defense. As we have seen, specifying the nature of the defense is testimonial. If the state will use the discovery response itself as a piece of evidence in its case-in-chief, ${ }^{169}$ as we have assunied in this hypothetical, then, that use violates the fifth amendment just as the use of the deposition would in the first hypothetical.

On the other hand, if the state prohibits direct use of the defendant's discovery response, such a limited disclosure would rarely be sufficiently incriminating to violate the fifth amendnient. Though helpful to the prosecution by narrowing the focus of its proof, the disclosure does not violate the privilege against self-incrimination because it provides inadequate information for the state to exploit. ${ }^{170}$

168. The fifth amendment threat in the second example results almost exclusively from derivative use of the information to incriminate the defendant; information in the first example may be used either directly or derivatively against the defendant. The distinction has no impact on the resolution of the testimonial issue, however.

169. In a homicide or assault case, for example, the state could use the notice of self-defense as an admission by the defendant proving his identity as the person who inflicted the injury.

170. 2 W. LAFAVE \& J. ISRAEL, supra note $164, \S 19.4$ at 520; Van Kessel, supra note 72, at 888-89. But cf. Allen v. Superior Court, 18 Cal. 3d 520, 526 n.4, 557 P.2d 65, 68 n.4, 134 Cal. Rptr. 774,777 n.4 (1976). 


\section{Discovery of Witness Names and Addresses}

Once discovery goes beyond disclosure of the general nature of the defense to specification of the names and addresses of witnesses, the critical demarcation line is crossed whether or not the domestic evidentiary law or discovery rule permits direct use of the discovery response as a statement. Specification of the nature of the defense, together with the witnesses who will support it, is sufficient to mcriminate. The nature of the defense alerts the government to defendant's basic construction of historical events, and the names and addresses of defense witnesses gives the state sufficient information to develop usable evidence from the defendant's commumication.

\section{Discovery of Witness Statements}

Requiring the defendant to provide witness statements adds specificity to his construction of historical fact, but would rarely make an otherwise innocent disclosure incriminating. Without witness statements, disclosure of the nature of defense and witness identity would typically provide the prosecutor with sufficient information to develop whatever incriminating information was available. Thus, whether the rule violates the fifth amendment does not depend upon its requirement of witness statements; ${ }^{171}$ rather, it turns on whether the defense specified or the witness revealed might realistically incrimmate the defendant. ${ }^{172}$

In sum, the rules examined in this hypothetical are frequently unconstitutional, and while more realistic in form than those examined in the first, violate the fifth ainendment for the same reasons applicable to

171. The statement itself would not be usable under any generally accepted principle of evidence, either directly to prove guilt or to impeach the defendant's own testimony. The defendant could not be considered to have adopted the witness's version of events simply by providing his statement. If, however, the domestic evidentiary law were to consider that the defendant adopts the truth of the witness statements by providing them to the state, then turning over the statements would pose substantial incrimination problems; however, no state permits such use. But cf. United States v. Morgan, 581 F.2d 933, 937 n.10 (D.C. Cir. 1978) (by authorizing agent to present sworn statement to magistrate, government adopted testimony of agent).

172. In Richardson v. District Court, 632 P.2d 595 (Colo. 1981) (en banc), the Colorado Supreme Court held that the state's discovery rule, which required the defendant to reveal both the nature of his defense and his witnesses, did not permit the prosecution to obtain witness statements. The court noted the absence of any specific provision covering witness statements in the rules and suggested constitutional foundations as well for the restriction:

The exclusion of non-expert witnesses' statements from prosecutorial discovery, far from being an oversight, reflects a purposeful decision to prevent the impairment of constitutional rights that arguably could result from a rule permitting the court to enlarge the categories of prosecutorial discovery on the basis of an ad hoc evaluation of each case.

Id. at 599. The court did not explain how providing witness statements qualitatively adds to the threat to constitutional rights otherwise posed by the requirement that the defendant disclose his defense and supporting witnesses.

Though its concern for potential violation of the fifth amendment is a valid one, the Colorado court's analysis of the point at which the violation occurs is misguided. 
the pretrial deposition considered earlier. In both hypotheticals, the defendant is required to make testimonial statements that lie knows the state may use to incriminate him as a condition of his right to present his defense.

In botli of these liypotheticals I assunie a critical fact that would not be present in the typical discovery situation: the defendant is fully aware that his disclosures can be and will be used to strengtlien the state's case against him. As a result, the prejudice to the defendant from the operation of the rule is readily apparent.

Thus, these liypotheticals do not deal witl the constitutionahity of rules, sucli as the rule at issue in Williams, that require advance specification of the defenses im situations im whicl the defendant is uncertain as to the effect his disclosure will liave. In the following hypothetical, I will examine the scope of the Court's approval of the rule at issue in Williams by reintroducing the complicating factor of uncertainty.

\section{Hypothetical Case Three: Typical Discovery Requirements with Uncertainty Present}

The constitutionality of most discovery rules is difficult to analyze precisely because they generally mclude the complication of uncertainty. Here, as before, the state requires the defendant personally to give notice of any defense he intends to present along with the names and addresses of any witnesses lie would call and threatens exclusion if notice is not provided. But the defendant in this liypothetical does not have full knowledge of the consequences of his choice.

The typical discovery situation contains uncertainty on a number of issues. First, the defendant may be uncertain both of the strength of the case the state will present against him ${ }^{173}$ and of the necessity or importance of lis testimony. Second, he may be unsure low incriminatimg his testimony will prove to be. ${ }^{174}$ Third, a reviewing court will face uncertainty over the true impact of discovery upon the conduct and motivations of the defendant. ${ }^{175}$

Assuredly, the pressures flowing from the defendant's uncertainty concerning the strength of the state's case against him reach constitu-

173. The defendant may be uncertain for either of two reasons. First, he may have incomplete discovery of the state's evidence. Second, even with complete discovery the defendant might remain uncertain because the strength of the case actually presented often varies substantially from the potential evidence available. See infra note 180.

174. At least three subsidiary issues are involved here: (1) Will his disclosure be useful to the state's case? (2) Will the state recognize or develop the incriminating value of the disclosure? (3) Will the state choose to use the incriminating information, assuming it recognizes its potential?

175. The court's uncertainty remains whether or not the defendant testifies: How much did the fear of incrimination motivate the defendant not to testify? Or, to what extent did the fear of the preclusion penalty cause him to divulge the requested information? 
tional dimensions. The Supreme Court made this clear with its analysis of the practice at issue in Brooks v. Tennessee. ${ }^{176}$ In Brooks, the state required the defendant to testify as the first witness if he was to testify at all. The rule attempted to prevent the criminal defendant, who has the constitutional right to be present throughout the trial, from tailoring his testimony to match that of other defense witnesses whose testimony he could otherwise hear before taking the stand. ${ }^{177}$ The Court observed that uncertainty concerning the effectiveness of his other witnesses may have legitimately motivated the defendant to exercise his right to remain silent until their value had been "realistically assessed." 178 As a result of exercismg that right to remain silent, however, his testimony was barred from the case. The Court held that burden to be impermissible. ${ }^{179}$ Brooks thus could be read to mean that where the defendant's uncertainty legitimately encourages the defendant to delay a decision on whether to waive his right against self-incrimination, the state may not penalize that delay by barring his testimony.

In my hypothetical, the pressures created by the unknown are substantially more powerful than im Brooks because the defendant faces far greater uncertainty. First, unless the state's discovery rules permit total disclosure of its evidence, he will not know the state's potential case. Second, he will not have had the opportunity as the defendant in Brooks had to view that potential case as actually presented in the courtroom. ${ }^{180}$ Third, he will not know what, if any, use the state will make of his response to the discovery rule-whether it will use his disclosures at all or will use then directly or derivatively to develop other incriminating information.

The defendant here is also faced with more complicated decisions than the single issue facing the defendant in Brooks. These separate, yet interrelated, decisions might well exacerbate the effect of uncertainty. For example, the trial judge has not yet ruled on the sufficiency of the state's case. Assuming the motion for a judgment of acquittal is denied, the defendant has not had a chance to inake the strategic decision

176. 406 U.S. 605 (1972).

177. Id. at 607 .

178. Id. at 610 .

179. Id. at $610-12$.

180. As Justice Black observed in his dissent in Williams, the potential prosecution case and that which is actually presented in the courtroom may vary greatly. Williams v. Florida, 399 U.S. 78, 109 (1970).

Where the potential for incrimination from the disclosure is not immediately apparent, the defendant will face the additional uncertainty of whether the state will recognize the incriminating value of his disclosure and use it against him. Whether such uncertainty increases pressures under the fifth amendment is unclear. In the pretrial setting, the defendant may assume a "worst case" scenario with the result that the pressures are increased. Alternatively, he may optimistically assume the state will remain ignorant of the incriminating potential and so lessen the pressure. 
whether to present no defense and challenge the denial of his motion to acquit on appeal or, more likely, to rest and argue the case to the jury on the basis of the state's failure to meet its heavy burden of establishing guilt beyond a reasonable doubt. A decision to provide the required notice could harm his chances of success at each of these points.

Facing such uncertainty, a defendant may make the reasonable decision to follow a conservative strategy and not provide the discovery. ${ }^{181}$ Or he may choose to provide the discovery out of fear of the preclusion sanction. ${ }^{182}$ Does Brooks then mean that any discovery rule permitting use of the defendant's disclosures in the prosecutor's case-im-chief is unconstitutional because the defendant's decision to testify or remain silent is not "the unfettered exercise of his own will"? ${ }^{183}$ Clearly not; as we saw earher, ${ }^{184}$ not all procedural rules that create additional pressures on the defendant's decision to exercise his fifth amendment right are unconstitutional. Rather, the constitutionahity of the hypothetical rule turns on the extent to which the pohicies underlying the right are impaired, as balanced against the legitimacy of the state's interest in the rule.

\section{Impact of Procedural Issues: The Character of the Defendant's Response}

\section{a. Defendant Provides Discovery}

The facts of Williams provide a good reference point for examining the procedural issues presented by this hypothetical rule. ${ }^{185}$ There, peti-

181. At least as a theoretical matter, the government's "heavy" burden should counsel silenceunless the defendant is confident that the state has established its case sufficiently. See Note, supra note 72 , at $1007-08$.

182. Either result may violate the fifth amendment. In Brooks, the Court held that where the defendant failed to testify first, preclusion of his testimony constituted an unconstitutional penalty upon the exercise of his right not to take the stand. 406 U.S. at 610-11. It concluded that his rights would also have been violated had he taken the stand to avoid the preclusion penalty. Id. at 611-12; see also supra note 91 .

183. Malloy v. Hogan, 378 U.S. 1, 8 (1964). In Brooks, the Court quoted this language and relied upon it when concludiug that the Tennessee statute violated the defendant's fifth amendment rights. 406 U.S. at 610-11.

184. See supra notes $155-70$ and accompanying text.

185. The facts of Williams also illustrate the limited procedural opportunities for challenging discovery when there is no compulsion in its pristine form. When the defendant faces an immediate external penalty for remaining silent, he may enforce his fifth amendment rights by refusing to provide the testimony and challenging the penalty exacted against him. See, e.g., Lefkowitz v. Cunningham, 431 U.S. 801,804 (1977) (when defendant refused to comply with statute that required him to testify to grand jury or be disqualified from holding public office, his automatic disqualification permitted him to sue to enjoin enforcement of statute). In contrast, a defendant in the discovery context faces no sanction outside the upcoming criminal trial. Thus, he has no separate vehicle with which to litigate his constitutional claim.

Moreover, pretrial interlocutory appeals, which are limited even in civil litigation, are even more restricted in most criminal cases. $3 \mathrm{~W}$. LAFAVE \& J. ISRAEL, supra note $164, \S 26.2(\mathrm{~b})$. The 
tioner admitted freely from the beginning of the case that he intended to use an ahibi defense. ${ }^{186} \mathrm{He}$ did not protest the requirement that he divulge the nature of his defense. ${ }^{187}$ Second, he made no claim that the state utilized that notice either directly or derivatively in its case-in-chief. Third, because he comphed with the notice once his motion for a protective order was denied, a record was available that demonstrated that the state did not use the notice against him. ${ }^{188}$ Finally, Williams raised no claim that he experienced any reasonable fear that the state would use his notice agamst him, and the record showed no reasonable basis for such fear. Accordingly, the Court was correct that Willianis's response to the alibi notice rule was not conipelled; Willianis failed to denionstrate that the rule had any adverse impact on the exercise of his fifth aniendnient rights.

The question ren1ains, however, whetlier the result would have been different had the defendant raised his fifth amendment objection in a different procedural context. Two factors may have been crucial to the Court's holding in Williams. Perhaps the petitioner has the burden of denionstrating prosecutorial misuse of his disclosure. If so, Williams failed to meet his burden of proof. Alternatively, the pivotal fact may

absence of a separate penalty together with the restriction on pretrial appeal of discovery rulings force the defendant to challenge a discovery ruling as part of his overall appeal. He must proceed to trial and if convicted, challenge the state's use of the information, when he complies with the discovery rule, or challenge the preclusion of his testimony, when he declines to do so.

The absence of a separate appellate remedy may be largely responsible for the relative lack of constitutional challenges to discovery requirements. Defendants probably remain entirely silent about a potentially damaging defense when the defense, though not frivolous, is of marginal utility, and when the state could effectively use the information provided in its case-in-chief. Substantially incriminating information may simply be too dangerous to reveal when the defendant is not assured that it cannot be used to convict him.

186. Williams v. Florida, 399 U.S. 78, 79, 84 n. 15 (1970).

187. Id. at 84 n.15.

188. The path chosen by Williams has a number of advantages for the efficient administration of justice. First, when the defendant provides the required notice, his ability to manufacture bogus issues is severely limited. See Luce v. United States, 469 U.S. 38, 42 (1984); New Jersey v. Portash, 440 U.S. 450, 462 (1979) (Powell, J., concurring). By contrast, if he can raise the issue without providing disclosure, a defendant can claim that he was deterred from presenting a defense, when in fact he had no desire to introduce any evidence. The Court observed in Luce that a defendant's guarantee to testify if granted relief "is virtually risk free because of the difficulty of enforcing it," 469 U.S. at 43, and expressed the view that "an accused's decision whether to testify "seldom turns on the resolution of one factor.' "Id. at 42 (quoting Justice Blackmun's dissent in Porfash, 440 U.S. at 467). Unfortunately, it is practically impossible to distinguish defendants with manufactured claims from others with legitimate desires to testify who are in fact deterred from doing so by a reasonable fear of incrimination.

Second, if actually given, the court can observe some of the actual consequences of providing the notice, rather than being forced to speculate. Finally, providing notice and proceeding to trial also assures the court that harm is real rather than a sincere but inaccurate anticipation. By contrast, courts will often have difficulty determining precisely when a claimed fear of incrimination is reasonable since generally a defendant may not be required fully to specify the reason he fears incrimination. See infra notes 190 \& 195. 
have been that Williams's response was neither used to incriminate him, nor had such potential. Since Williams provided discovery and alleged no reasonable fear of specific incrimination, it is difficult to determine which of these factors the Court found decisive.

\section{b. Defendant Declines to Provide Discovery Under Claim of Self- Incrimination}

Assuine that Williams inakes a different response to the notice of alibi rule. After his request for a protective order is denied, rather than supplying discovery, he argues that the notice is potentially incriminating because his alibi witnesses might provide evidence or leads that could moriminate him in this and other crimes. ${ }^{189} \mathrm{He}$ declines to be more specific, arguing that the law does not require him to prove his guilt in order to assert the privilege. ${ }^{190} \mathrm{He}$ further contends that he is faced witl uncertainty pressures. He argues that he will not know until the close of the state's evidence whether it can establish a prima facie case or whetler its case is so weak that he should present no evidence and argue to the jury that the prosecution failed to prove his guilt. He asserts that he ultimately may want to present an alibi defense but that the rule improperly burdens his right to remam silent until he can effectively assess the situation by requiring that he provide discovery before trial or lose his right to present a defense.

Furtlier assume that after the trial court demes the motion for a protective order, the government presents a case that withstands spirited attack by defense counsel, and the court denies a motion for judgment of acquittal at the close of the state's case. The defendant now asks to be allowed to present his alibi defense because, having seen the government's case, he realizes that he must run the risk of incrimination through the alibi witnesses in order to avoid conviction. The trial court responds that lis case is exactly like hundreds arising in the state yearly and that to grant relief from the rule on this showing would be to destroy the notice of alibi rule. Accordingly, the court dernes Williams's request to present his alibi and precludes both his testimony and that of any alibi witnesses. ${ }^{191}$

189. This argument is generally based on Justice Black's dissent in Williams. 399 U.S. at 110 .

190. Marchetti v. United States, 390 U.S. 39, 50 (1968); Hoffman v. United States, 341 U.S. 479, 486 (1951); see also infra note 195.

191. In spite of the greater efficiency of requiring the defendant to provide discovery before raising fifth amendment challenges, see supra note 188 , courts have traditionally permitted a defendant to litigate his claim without first complying with the rule at issue. He may instead refuse to provide the potentially incriminating disclosure on the ground that it may be used by the state to incriminate him. See Stevens v. Marks, 383 U.S. 234, 246 (1966) ("A witness has . . . a constitutional right to stand on the privilege against self-incrimination until it has been fairly demonstrated to him that an immunity, as broad in scope as the privilege it replaces, is available and applicable to him."); see also Maness v. Meyers, 419 U.S. 449, 473 (1975) (White, J., concurring in 
Despite very little change in the substantive facts, this case begins to look substantially different from the Williams case. Now it strongly resembles Brooks-suggesting, perhaps, a different outcome from Williams. The result would not be different, however. Applying the analyses of these two cases to the hypothetical explains both why the Court would not reverse here and when the Brooks rationale will require holdmg a discovery rule unconstitutional.

The major distinction between the hypothetical and Brooks is that the statute in Brooks required that the defendant incriminate himself within the meaning of the fifth amendment or forfeit his right to testify; in contrast, the hypothetical rule requires no such incrimination. A criminal defendant has the absolute right under the fifth amendment not to be called to the stand in a criminal case. ${ }^{192}$ Requiring him to testify violates this constitutional provision, regardless of the tenor of his testimony. The Court held that Brooks could not be compelled by the pres-

the result). But cf. Luce v. United States, 469 U.S. 38, $42-43$ (1984) (states may permit claim on basis of anticipated harm since it satisfies "case or controversy" requirement but apparently need not do so).

When compulsion is present in a pristine form, the defendant may litigate the validity of his fifth amendment claim while refusing to provide the required statement. If the defendant is not given adequate assurances of immunity, his rights are violated at the moment he is compelled to answer, regardless of how the state may later use his testimony. See supra note 91 . If immunity is given, however, it not only prevents the government from improperly using his statements, it eliminates any violation by granting protection as broad as the privilege. Kastigar v. United States, 406 U.S. 441, 462 (1972).

Under the second compulsion model operating in the hypothetical, the violation of constitutional rights turns on the use the state makes of the statement, rather than the impropricty of confronting the defendant with certain choices. As a result, the state should not be required to permit litigation of a claim based on the anticipation of improper use of the statement. Rather, the state could require the defendant to provide discovery and proceed to trial before raising the claim, since a constitutional violation would occur only if the prosecution improperly used the statement.

Under such a procedure, however, the protections afforded the defendant - including the risk of persuasion regarding improper use of the information - must be as effective as those under use immunity. The Court has held that where the nature of the statement raises a reasonable fear that the state may use it to incriminate the defendant, it is a sufficient remedy to impose upon the government "the affirmative duty to prove that the evidence it proposes to use is derived from a legitimate source wholly independent of the compelled testimony." Kastigar, 406 U.S. at 460. Unless such a burden is placed on the government, the danger of undetected prosecutorial derivative use would not be curtailed. The defendant's fear of incrimination from disclosure would remain valid. In the typical discovery situation, no apparent justification exists for shifting the burden of demonstrating misuse by the prosecution to the defendant. Indeed, any such shift strikes directly at the substance of the defendant's constitutional right.

192. 8 J. W1GMORE, EvidENCE $\S 2268(2)$ at 406 \& n.6 (McNaughton rev. 1961) (universally held that the criminal defendant cannot even be called to the stand to be sworn); MCCORMICK ON Evidence $\S 130$ at 315 (E. Cleary ed. 1984); Patty v. Bordenkircher, 603 F.2d 587, 588 (6th Cir. 1979) ("We do not remember or find any cases where the prosecution has called a criminal defendant to the stand.... The general acquiescence of lawyers in a custom to the contrary suggests that Professor Wigmore's observations on this subject are correct . . . ."); United States v. Echeles, 352 F.2d 892, 897 (7th Cir. 1965) (" 'universally held' interpretation of this right prohibit[s] any person who is on trial for a crime from being called to the witness stand" (citing WIGMORE and MCCORMICK)). 
sures of uncertainty to incriminate himself in this way or suffer a penalty for asserting his right to remain silent.

Outside of the criminal trial courtrooin, the rights of the accused are different, however. For instance, he can be required to give a statement if he is protected against its direct or derivative use in a criminal case. ${ }^{193}$ Thus, while a defendant's uncertainty may be as great and the penalty for declining to provide a discovery statement the same, requiring his statement outside the criminal trial does not automatically violate the fifth amendment. Analyzed in this fashion, the results in Williams and Brooks are consistent under the fifth amendment. The rule in Brooks required the defendant to incriminate himself within the meaning of the fifth amendinent or forfeit his right to testify; Williams required him to provide information that did not threaten incrimination and that the prosecution, in fact, did not use to establish its case. ${ }^{194}$

193. Kastigar v. United States, 406 U.S. 441 (1972). See also S. BEALE \& W. BRYSON, Grand Jury Law and Practice $\S 6.14$, at 78 (1986) (while fifth amendment prohibits calling defendant at trial, majority view is that he may be called at grand jury and must invoke privilege to incriminating questions); United States v. Wong, 431 U.S. 174, 179 n.8 ("There is no constitutional prohibition against summoning potential defendants to testify before a grand jury."); United States v. Washington, 431 U.S. 181, 189 (1977) (status as potential defendant "neither enlarges nor diminishes the constitutional protection against compelled self-incrimination" when called to appear and answer questions before grand jury); United States v. Dionisio, 410 U.S. 1, 10 n.8 (1973) ("The obligation to appear is no different for person who may himself be subject of the grand jury inquiry"; he may be required to provide nontestimonial evidence).

194. See Berger, supra note 79 , at 78 .

Professor Westen argues that the two cases are irreconcilable. Westen, supra note 83, at 939-40. He argues that the fifth amendment protects a defendant equally against being compelled "to make incriminating statements" and being compelled to take the stand. Indeed, he contends, if anything, the right to be frec of compulsion to take the stand should have less protection since historically it is "a subsequent and subordinate development" to the right not to be compelled to make incriminating statements. He also argues that the defendant in Williams would have been under greater coercive pressure due to the uncertainty from having less information about the government's case than did the defendant in Brooks. Id. at 954-56.

These arguments rest on the unsupported assumption that the notice of alibi rule in Williams required production of incriminating statements. Id. at $981 \mathrm{n} .198$. This assumption is erroneous. See infra notes 197-208 and accompanying text. Thus, the correctness of the two results does not turn on a determination of whether it is more, or less, prohibited to compel incriminating discovery than to compel testimony. Similarly, Professor Westen may be correct that a greater uncertainty as to the strength of the state's case places additional pressure on a defendant who faces discovery demands than was felt by the defendant in Brooks. Nevertheless, if the discovery rule does not threaten incrimination, the protections of the fifth amendment are not invoked.

Professor Westen argues that Brooks rests on the defendant's right to control the timing of his testimony. Id. at 975-85. The right of the defendant to exercise such control is a traditional part of our adversarial procedure; however, I contend that, rather than a separate right, that interest is part of the justification for fifth amendment protections against rules that require the defendant to speak at a time specified by the state or forfeit his right to testify later. See supra note 145 . See also Lapides, Cross-Currents in Prosecutorial Discovery: A Defense Counsel's Viewpoint, 7 U.S.F. L. REV. 217, 227-28 (1973) (also arguing that Brooks and Williams are inconsistent); Nakell, supra note 9, at $516 \mathrm{n} .382,500-02$; $c f$. Blumenson, supra note 33, at 148 (arguing that the two cases are consistent if discovery is carefully confined to evidence which defendant presently intends to introduce). 
i. Reasonable Fear of Incrimination: A Necessary and Sufficient Condition of a Valid Claim. In the Williams opinion, the majority was willing to assume that the alibi notice might prove incriminating because it nevertheless concluded that Williams was not compelled within the meaning of the fifth amendment. If Wilhams had claimed that he reasonably feared incrimination through the alibi notice, he would have raised an apparently more substantial claim of compulsion within the meaning of the Constitution. His claim ultimately would have failed, however, because revealing his ahibi defense would not reasonably have threatened to incriminate him. ${ }^{195}$ On that basis his case and Brooks are distmguishable.

In Williams, petitioner gave no explanation for reasonably fearing mcrimination from providing the notice. ${ }^{196}$ In his dissent, Justice Black suggested some potential dangers of incrimination: the defendant would be required to provide the names and addresses of person who have knowledge of him and his activities, and the state may discover new leads and evidence from such persons. ${ }^{197}$

Others have made similar arguments. ${ }^{198}$ This type of presentation is made in Scott v. State. ${ }^{199}$

Although the list [of witnesses] miglit not appear to be incriminating on its face, certain of the persons identified in such a list may be known felons, perjurers, accomplices, co-defendants, or individuals under suspicion or police surveillance. Moreover, the police may possess additional

195. The fifth amendment "protects against any disclosures that the witness reasonably believes could be used in a criminal prosecution or could lead to other evidence that might be so used." Kastigar, 406 U.S. at 445 (emphasis added). The court, rather than the person claiming the privilege, determines whether that fear is "reasonable." To do so the court examines the "implications of the question, in the setting in which it is asked." Hoffman v. United States, 341 U.S. 479,486 (1951). If these circumstances do not sufficiently demonstrate the danger, the witness bears the burden of providing further explanation. United States v. Edgerton, 734 F.2d 913, 919 (2d Cir. 1984); see also infra note 204.

196. In his brief, Williams provided only the most general argument on the incrimination issue:

While [the Fifth] Amendment ordinarily tests patently incriminating practices, the literal mandate is "to be a witness against himself". It is this mandate which is violated because while the alibi witness rule is only latently and by practical application incriminating, it still requires a defendant to furnish information which the state will use to its own advantage in an effort to convict.

Brief for Petitioner at 3-4, Williams v. Florida, 399 U.S. 78 (1970), reprinted in 69 LANDMARK BR1EFS 328-29.

He suggested, but only as a theoretical possibility, that compliance with the rule would adversely affect a defendant by prematurely "locking in" a defense and intimidating defense witnesses. Brief for Petitioner at 6, Williams v. Florida, 399 U.S. 78 (1970), reprinted in 69 LANDMARK BRIEFs 331. Obviously, such fears did not deter Williams from providing the notice or presenting an alibi defense; neither of those adverse effects occurred. Furthermore, Williams claimed no reasonable fear of future harm from the notice.

197. Williams v. Florida, 399 U.S. 78, 110 (1970).

198. See, e.g., Van Kessel, supra note 72, at 891 n.147; Westen, supra note 83, at 981 n.198.

199. 519 P.2d 774 (Alaska 1974). 
incriminating information about soine of the witnesses and an accused's reference to such persons may tend to arouse suspicion about his relationship with the witness or may tend to implicate him in the criminal activities of such witnesses. 200

These broad arguments that the alibi notices are incriminating go too far. ${ }^{201}$ As a general matter, alibi information is not incriminating under traditional fifth amendment principles. First, the defendant is asserting that the witness will exculpate him by placing him elsewhere at the time of the crime. The nature of his offer of proof, if true, suggests no direct or derivative possibility of imcrimination. Second, in the typical case, there is no "real and appreciable" danger of incrimination. ${ }^{202}$ While incrimination certainly does not have to be direct or certain, and providing inforination that would "prove a significant 'link in a chain' of evidence tending to establish his guilt" ${ }^{203}$ is also protected, there is little

200. Id. at 785 .

201. The court's argument in Scott that the notice collaterally incriminates the defendant, by revealing his association with others linking him to additional crines, fails on two grounds. First, the notice replicates exactly what will happen when he presents his defense at trial-the state will learn of his witnesses. Since the state may at that point use the information to charge him with other crines, it receives no additional advantage from the notice of alibi. See L. LEVY, Against the LAw $147-48$ (1974).

Second, in Scott, the court argued that if disclosure of the names and addresses of witnesses were required in another context, the practice's unconstitutionality would be plainly apparent: "We doubt, for instance, whether any court would uphold a statute or rule which would require the defendant to make such disclosure to the police at the station house." Scott, 519 P.2d at 786.

Indeed, the error of the argument in Scott can readily be seen by examining this analogy. Assume that the police routinely ask during booking that a defendant provide the naines and addresses of his close fanily members, friends, and associates. The information could provide the same "incriminating" leads that concerned the Scott court. Is it protected by the fifth ainendment?

The Supreme Court has suggested not. In Rhode Island v. Innis, 446 U.S. 291 (1980), the Court defined "interrogation" under Miranda v. Arizona, 334 U.S. 436 (1966), as "any words or actions on the part of the police (other than those normally attendant to arrest and custody) that the police should know are reasonably likely to elicit an incriminating response froin the suspect." Id. at 301 (emphasis added) (footnotes omitted). The majority of lower courts excludes responses to questions about friends and associates from the protections of Miranda-even where the prosecution explicitly uses the information to incrininate the defendant. See, e.g., United States ex rel. Hines v. LaVallee, 521 F.2d 1109, 1112-13 (2d Cir. 1975), cert. denied, 423 U.S. 1090 (1976); Toohey v. United States, 404 F.2d 907, 910 (9th Cir. 1968); see also 1 W. LAFAve \& J. ISRAEL, CrimiNaL Procedure $\S 6.7$ at 504 (1984); $c f$. United States v. Hinckley, 672 F.2d 115, 122-23 (D.C. Cir. 1982) (twenty-five minute substantive interview of defendant by FBI not typical of clerical procedure during booking).

The courts' rationale is that such questioning does not compel because interrogation as defined in Miranda "must refiect a measure of compulsion above and beyond that inherent in custody itself," Innis, 446 U.S. at 300, and this " 'questioning' does not enhance the pressure and anxiety generated by arrest and detention." Kamisar, Police Interrogation and Confession, in THE SUPREME CourT: TREndS AND Developments $1979-80$ at 83, 88 (J. Choper, Y. Kainisar \& L. Tribe ed. 1981). Because it does not materially threaten incrimination, such routine questioning adds little to the compulsion inherent in custodial situations.

202. Brown v. Walker, 161 U.S. 591,599 (1896).

203. Marchetti v. United States, 390 U.S. 39, 48 (1968) (footnotes oinitted); see also supra notes $190 \& 195$. 
reason to suppose that the dangers present here constitute such a link within the meaning of the fifth amendment.

Two examples of possible alibis test the limits of the argument that an alibi response is not incriminating. For the first, assume that the crime occurred in the defendant's apartment building and that his alibi would put him in the building but in another apartment within that building. The alibi exculpates in that it places him in another place at the moment of the crime, but it has a tendency to incriminate-to provide a "hink in the cham" of evidence by proving that he was nearby.

That atypical alibi will warrant fifth amendment protection; its facts have a tendency to prove guilt. This specific conclusion does not mean, however, that all ahibis are protected. In this special situation, the defendant can demonstrate the substantiality of the danger of incrimination by in camera proffer. ${ }^{204}$ The fact that some alibis are sufficiently incriminating neither privileges all alibis nor relieves a defendant with a legitimate claim from complying with traditional requirements of adequately demonstrating that danger.

For the second test, assume that the alibi is false and that the defendant directly procured this false testimony. Revealing the identity of the witness may result in the prosecution's learning of the defendant's actions. Such information would then be admissible in the prosecution's case-in-chief as "consciousness of guilt." 205 Certainly that is incriminating, but it is not protected by the privilege against self-incrimination.

At the core of the policies behind the fifth amendment is protection against the "cruel trilemma of self-accusation, perjury, or contempt."206 That the defendant may not be forced to lie rather than incriminate himself does not mean that he is free to choose to lie instead of remaining silent. ${ }^{207}$ Another way to explain this result is that when a defendant is asked to show why his alibi response may incriminate him, it is not an acceptable response to say "because the government may learn that I am lying about my ahibi and use the fact of the lie against me." The law is

204. See, e.g., Butcher v. Bailey, 753 F.2d 465, 470 (6th Cir.), cert. dismissed, 106 S. Ct. 17 (1985); United States v. Edgerton, 734 F.2d 913, 921 (2d Cir. 1984); United States v. Goodwin, 625 F.2d 693, 701-02 (5th Cir. 1980); see also United States v. Neff, 615 F.2d 1235, 1239-40 (9th Cir.), cert. denied, 447 U.S. 925 (1980); United States v. Weisman, 111 F.2d 260, 261-62 (2d Cir. 1940). See also supra note 195.

205. A similar hypothetical is suggested by Van Kessel, supra note 72, at $891 \mathrm{n} .147$.

206. Murphy v. Waterfront Comm'n, 378 U.S. 52, 55 (1964).

207. In United States v. Knox, 396 U.S. 77, 82-83 (1969), the Supreme Court acknowledged that Knox, a professional gambler, could not have been properly compelled by the Internal Revenue Service to file a truthful tax return because such a response would have incriminated him. He could have either refused to file any return and raised a fifth amendment defense to the prosecution or responded truthfully and challenged the admission of that evidence on the ground that his response was compelled in violation of the fifth amendment. He could not, however, perjure himself and then raise the fifth amendment as a defense. That choice did not constitute testimonial compulsion. 
well settled that the fifth amendment does not protect a witness against being compelled to testify when the only possible incrimination he can identify is that his responses will be perjurious. Indeed, immunity offered to witnesses explicitly notifies the witness that he may be prosecuted for perjury in spite of the immunity. ${ }^{208}$

In sum, discovery of the alibi defense is justified by the absence of a reasonable prospect of incrimination in the typical case. The justification for permittimg prosecutorial discovery of the alibi defense thus derives froin a very different basis from discovery of the insamity defense. Witl respect to the insamity defense, discovery rests on extraordinary, wellfounded arguments of practical necessity and fundamental litigative fairness. While the state's interest in avoiding surprise froin an alibi defense, which can easily be fabricated and presented at the "eleventh lour," is "both obvious and legitimate,"209 such justification liardly rises to the critical level of need to discover the insamity defense. Rather, notice of alibi rules are justified because there is no reasonable likelihood of incrimination; thus, discovery does not violate the fiftl ainendment. ${ }^{210}$

Thus far, I have discussed in detail only discovery rules requiring disclosure of msanity and alibi defenses-rules which, for very different reasons, are constitutional under the fiftl ainendment. Yet neither of the justifications supporting these rules applies to other discovery rules requiring the disclosure of potentially mcriminating information. ${ }^{211}$ The question remains, then, whether suclı rules are necessarily invalid or

208. United States v. Apfelbaum, 445 U.S. 115, 126-32 (1980); United States v. Wong, 431 U.S. 174 (1977); United States v. Mandujano, 425 U.S. 564, 577-78 (1976) (plurality opinion); Glickstein v. United States, 222 U.S. 139, 141-42 (1911).

209. Williams, 399 U.S. at 81.

210. The federal discovery rules for the alibi and insanity defenses reflect this basic difference. FED. R. CRIM. P. 12.1, covering the alibi defense, makes no provision for use immunity of the information derived. Rule $12.2(\mathrm{c})$, pertaining to insanity, prohibits use of the information obtained except on the issue of insanity, see supra note 148; the Advisory Committee Note bases the restriction on constitutional grounds. 97 F.R.D. 294, 296 (1983). The 1978 ABA STANDARDS, on the other hand, would restrict use of discovery under both defenses to rebuttal of the evidence offered by the accused. 1978 ABA STANDARDS $\S 11-3.3(\mathrm{~b})$.

211. These two defenses represent the extremes of the continuum on which other defenses may be placed. In order to determine the constitutionality of their discovery, the other defenses may be compared with the characteristics of these two defenses. The key elements are the degree to which the defense will incriminate and the extent to which discovery is necessary for the adversary system to operate at all.

Traditional characterizations of defenses as "affirmative" or "confession and avoidance" are not sufficiently helpful for the analysis. The incrimination question must be answered on the basis of the specific facts and circumstances of the individual case. Moreover, the timing of the disclosure and the nature of government use must be carefully examined.

I believe that no defense but insanity will satisfy the analysis's necessity rationale. On the other hand, other defenses may be like the alibi defense and, typically, present no appreciable prospect for incrimination. 
whether they can be enforced in a manner that would meet fifth amendment objections.

ii. Use Immunity-An Adequate but Impractical Solution. Discovery of some defenses, such as self-defense, clearly requires an incriminating response from the defendant. Nevertheless, under the second model of compulsion, a rule requiring such discovery is not necessarily invalid. As shown earlier, a state may require incriminating disclosures if it can later demonstrate that none of that information was used against the defendant. ${ }^{212}$ Use immumity is thus a satisfactory answer to the possibility of incrimmation, and rules providing such protection meet fifth amendment objections. Constitutionality notwithstanding, that solution is highly impracticable in the discovery area. Proving an independent basis for prosecutorial knowledge would impose enormous administrative burdens on the state and would make the overall costs of discovery far greater than its benefits. ${ }^{213}$ The costs would be particularly high in jurisdictions that have very broad, mdependent discovery as a matter of course.

Probably the only method to assure protection against use of the defendant's disclosures im the prosecution's case would be to seal the evidence available to the state before discovery is obtained from the defense. But this metlod too is impractical. The prosecution obtains discovery in order to counter the defense case, and the state generally cannot accomplish that task without comparing defense evidence with the prosecution's version of events. Effective preparation usually requires consultation between the prosecutor and his witnesses and imvestigators concerning the evidence to be introduced by the defense. Once defense witnesses have been questioned and the state's witnesses have been consulted in response, it would be difficult to demonstrate that the state's case is independently obtained should any of the defense evidence incrimimate. $^{214}$

The difficulties of use immunity have been dealt with in the insanity

212. See supra note 191.

213. See Van Kessel, supra note 72, at 896-98.

214. Litigation on the constitutionality of Montana's discovery statute illustrates the conflict between use of discovery for its intended purpose, aiding prosecutorial preparation, and the real possibility of incrimination.

After unsuccessfully challenging Montana's discovery statute as facially unconstitutional, State ex rel. Sikora v. Thirteenth Judicial District, 154 Mont. 241, 462 P.2d 897 (1969), the defendant provided notice that he intended to rely on either insanity or self-defense, or both. He was convicted at trial and this time challenged the constitutionality of the statute collaterally in federal court.

The district court seriously considered Radford's claim that notices under insanity and selfdefense differed critically from a notice of alibi because of the possibility that the state would use them to help prove its case. It found, however, "[a]s shown by the affidavit of the Yellowstone County Attorney, no investigation was undertaken of the witnesses petitioner named and no advantage was taken of petitioner's notice in presentation of the state's case-in-ehief." Radford $v$. Stewart, 320 F. Supp. 826, 829 (D. Mont. 1970), aff'd, 472 F.2d 1161 (9th Cir. 1973). The distriet 
area. There, the government's burden of proving an independent source for its evidence has been reduced to conform to the practicalities of the litigation process. As a result, the defense has the burden of proving that the government used an inproper source in its case.

In United States v. Stockwell, ${ }^{215}$ the Second Circuit recently examined the burden of proving comphance with the "use immunity" provisions pertaming to the insanity defense under Rule 12.2 of the Federal Rules of Criminal Procedure. Before trial, the prosecutor histened to a tape recording of an interview between a government psychiatric expert and the defendant. The Court of Appeals recognized that the fifth amendment mandated that defendant's statements could be used only on the issue of insanity. ${ }^{216}$ Nonetheless, the court rejected the defendant's argument that, under Kastigar v. United States, ${ }^{217}$ the government inust deinonstrate that "the evidence it intended to offer at trial on issues other than sanity was based entirely on its imdependent imvestigatory efforts and not on the information obtained in or derived from the examination."218

The court reached its conclusion primarily on the basis of practical necessity. It concluded that when the defendant raises an insanity defense he is not in the position of a witness whose testimony has been immunized. Whereas the immunized testimony cannot be used for any purpose, a psychiatric examination is admissible on the issue of insanity. Furthermore, the discovery rule necessarily anticipates that the prosecutor will receive the results of the exainination so that she can prepare her rebuttal. The court concluded:

Since there is nothing presumptively improper in the government's use of the results of a psychiatric examination at trial, it would be illogical to conclude that the conducting of such an examination gives a defendant an automatic right to a hearing in which the government must demonstrate that it does not intend to misuse the information it has

court further found that the notices "did not provide the state with any evidence which was used against petitioner." Id. at 831 .

By completely undermining the utility of the rule, the state avoided a conflict between its discovery rule and the ffth amendment. Pretrial discovery is to permit the prosecution time to investigate the defense and to develop rebuttal evidence. In that respect, the prosecutor treated the notices as if they did not exist. Under such constraint, required disclosure hardly furthers any substantial state interest. While it may not violate the Constitution, its minimal benefits fail to justify the threat posed by prosecutorial misuse of the rule. Cf. Van Kessel, supra note 72, at 894-96 (requiring disclosure of defenses after prosecution establishes prima facie case would avoid constitutional issues but would not substantially further state interests in having sufficient time to investigate).

215. 743 F.2d 123 (2d Cir. 1984).

216. Id. at 125.

217. 406 U.S. 441 (1972).

218. Stockwell, 743 F.2d at 126. 
obtained. $^{219}$

Finding that the record affirmatively established only that the prosecutor used Stockwell's statements on the insanity issue, the court required no further showing. The government was not forced to prove that it obtained its evidence independently. ${ }^{220}$

The result in Stockwell seems sensible, but is extraordinary nonetheless. It means that the defense bears the burden of proving iinproper use of disclosures which are a prerequisite of raising the insanity defense. Under Kastigar, shifting the burden is improper because inmunity would not then provide the defendant with assurances adequate to override his fifth amendment objection. His behef that his disclosures might incriminate him would indeed be reasonable, and he would not be provided with an adequate remedy. Kastigar means that if the defendant's original fear of incrimination is reasonable, he cannot be required to provide discovery, unless, that is, practical necessity is held to be a sufficient justification for eliminating the protections of the fifth amendment. ${ }^{221}$

Fifth amendment protections have thus been compromised on two fronts in the insamity area. Courts have accepted that the need for an msight into the defendant's mind justifies both requiring him to provide admittedly mcriminating information that the state may use to prove his samity and risking other uses of discovery that may aid in proving factual guilt. In other discovery areas where necessity is not as great, however, no similar theory justifies requiring the defendant to provide discovery he reasonably fears will mcriminate, unless he is provided protections equivalent to use immumity.

Based on the above analysis, Williams cannot inean that the issues of compulsion and incrimination are separate and unrelated. The first and second hypotheticals show that when a discovery rule requires dis-

219. Id. at 127.

220. The court acknowledged that under some circumstances the government's actual trial conduct might "raise a significant question as to whether it had improperly used information obtained" and warrant a Kastigar-type hearing. Nonetheless, such a hearing was not required merely by the fact that the prosecution had discovered potentially incriminating information. Stockwell, 743 F.2d at 127. The court nevertheless encouraged the prosecution to avoid directly monitoring psychiatric examinations and to rely instead on the psychiatrists' reports which would be less likely to reveal factual information that might be misused. Id.

221. Under traditional analysis, the fifth amendment can be satisfied two ways. Either a showing of a reasonable fear of incrimination must be accepted as sufficient to avoid the requirement of providing pretrial discovery, or the state must assure the defendant of effective use immunityenforced in the manner specified by Kastigar. When the state does not guarantee protections equivalent to use immunity, it cannot insist that the defendant litigate the issue by providing the disclosure and proceeding to trial. See supra note 191. Since assuring sufficiently broad immunity is virtually impossibile in the discovery area, the second option is not viable. Thus, where the defendant's fear of incrimination is reasonable his fifth amendment claim is valid, and because no alternative procedures are readily available to eliminate the reasonable fear, such a claim must be held itself sufficient under the fifth amendment. 
closures that will incriminate the defendant, it violates the fifth amendment if the state uses that information so obtained in its case-in-chief. The third hypothetical shows that even when the prosecution does not actually use the disclosures, preclusion of a defendant's testimony unconstitutionally burdens his fifth amendment rights if the prospect of such use produces a reasonable fear of incrimination and prompts his decision not to provide the required discovery. Even should the defendant provide the disclosure, his response may properly be considered coinpelled. Unless the state can demonstrate that it did not use the information indirectly in its case-in-chief, traditional fifth amendment doctrine requires reversal of conviction. Compulsion exists whenever a discovery rule requires that the defendant provide mcriminating information that may be used by the state to inake out its prima facie case. Compulsion thus results either from direct use of discovery information in the prosecution's case or from the reasonable possibility that required disclosures will incriminate in the absence of protections equivalent to use immunity.

A number of basic principles einerge from this analysis. First, absent conscious fabrication by the defendant, a state's discovery rule may not perimit use of the required disclosure in the prosecution's casein-chief. Second, the rule must provide use immumity or equivalent protections. If it does so, discovery is constitutional, but without such protections, the rule is constitutionally deficient. Third, given the basic legitinate purposes of prosecutorial discovery, which are to permit the state to prepare rebuttal testimony and to investigate the validity of the defendant's proposed defense, effective use immunity will be inpractical in many cases. The admimistrative burdens of enforcing immunity would almost certainly bring to a halt any extensive discovery systein. Fourth, when the state's discovery requirement is based upon a sufficiently strong foundation, as in the insanity area where only the defendant possesses the critical data, the possibility of imcidental incrimination may be justified by practical necessity. The practical necessity rationale directly comproinises the privilege against coinpulsory self-incrimination, however, and can only be justified by such a strong, indeed compelling, interest. Finally, some defenses, such as alibi, raise no substantial likelihood of incrinination. Discovery as to those defenses fails to violate the fifth ainendment because the danger of incrimination is insufficient, not because discovery rules as a class fall outside the protections of the fifth amendment.

\section{Hypothetical Case Four: Discovery Deposition Limited to Impeachment}

The last hypothetical I will discuss is sinilar to the discovery-deposition hypothetical. Assuine the state enacts a discovery rule that 
requires the defendant to give a pretrial deposition if he intends to testify, but restricts use of the deposition to impeachment of his testimony if he takes the stand. Assume also that the rule makes the restriction against uses other than impeachment effective by providimg that the deposition shall be taken outside the presence of the prosecutor and shall remain sealed until the defendant takes the stand.222

As discussed im Part I, discovery rules involve consequences significantly different from testimony at trial by requiring the defendant (1) to disclose information earlier which may be critical if early disclosure permits the state to make a different use of the inforination and (2) to make a separate "statement." 223 This hypothetical emphasizes the statement aspect of discovery. The distinction between pretrial disclosure and presentation of a defense at trial does not turn upon the timing of the disclosure or its use in the state's case-m-chief. Rather, direct use of the disclosure as evidence, albeit only to impeach his testimony, harms the defendant with his own testimomial act in a way that would not have occurred if discovery had not been required.

As did the earher hypothetical, which made the deposition available for all purposes, this rule threatens no external coinpulsion. A defendant is not punished directly, by contempt or otherwise, if he dechines to provide the deposition. Any compulsion is provided solely by his desire to present testimony and by the cost of exclusion of his testiniony if he refuses to provide the deposition before trial.

As stated earlier, the defendant's fifth amendment right is not threatened if his statement cannot incriminate him. ${ }^{224}$ The fifth amendment, therefore, is not implicated unless using the defendant's own statement to impeach him constitutes self-incrimination. In New Jersey $v$. Portash, ${ }^{225}$ the Court held that where the statement is compelled under the "pristine" model of compulsion, the privilege against compulsory self-incrimination prohibits all testimonial uses of a defendant's statements, includimg their use to impeach his subsequent inconsistent testi-

222. Given this effective protection against use of the deposition by the state in its case-in-chief, the hypothetical has the essential characteristics of a discovery rule where the information sought has no prospect of incriminating the defendant. If not incriminating, the disclosure would serve no purpose in the government's case-in-chief.

Professor Westen maintains that a restriction against prosecutorial use of the deposition is unnecessary to preserve the constitutionality of the hypothetical rule. Westen, supra note 83, at 95859. He contends that the deposition would provide an effective method for preventing a defendant from tailoring his testimony to match that of his other witnesses without affecting the timing of his testimony, which Westen considers the critical but unstated basis for the Court's opinion. Id. at 975 78. In my opinion, Brooks rested on the fifth amendment basis stated by the Court, see supra notes $145 \& 194$, and effective protection against use of discovery in the state's case-in-chief is essential to the rule's constitutionality.

223. See supra text accompanying note 70; see also supra text accompanying notes 161-68.

224. See supra note 63 and accompanying text.

225. 440 U.S. 450 (1979). 
mony. ${ }^{226}$ Portash, however, does not apply directly to prohibit any impeachment use of the statement here because there is no direct, external compulsion. ${ }^{227}$ Rather, whether the fifth amendment is violated again turns on whether the impact of the rule impinges significantly upon any of the policies behind the fiftl amendment. The forces that will produce a response from the defendant in this situation are largely those considered in the first liypotletical in which the disclosure could be used by the state in its case-in-chief. The task is to determine how those forces differ in degree and effect in this new situation. ${ }^{228}$

\section{The Impact of the Rule}

One possible effect of the rule is to deter a defendant from giving the required deposition; as a consequence, le will be barred from testifying. Alternatively, the rule may cause defendants to provide the deposition out of fear of that very penalty sliould they exercise their riglits to remam silent. Starting with the first of the two potential effects of the rule, the question remains whetler the threat of impeachment use would logically deter the defendant from giving the deposition.

Had the defendant absolute assurance that his deposition would not

\section{Id. at 459-60. See Miranda v. Arizona, 384 U.S. 436, $476-77$ (1966):}

The privilege against self-incrimination protects the individual from being compelled to incriminate himself in any manner; it does not distinguish degrees of incrimination. Similarly, for precisely the same reason, no distinction may be drawn between inculpatory statements and statements alleged to be merely "exculpatory." If a statement made were in

fact truly exculpatory it would, of course, never be used by the prosecution.

See also Rhode Island v. Innis, 446 U.S. 291, 301 n.5 (1980).

Also, there may be substantial, even imsuperable, difficulties in attempting to limit use of statements of the defendant to impeachment. Such use has the arguably unavoidable effect of proving the defendant's guilt where the inconsistency involves testimony establishing elements of the crime. See Bradley, supra note 142 , at 426 (prior inconsistent statements may supplement the prosecution's case-in-chief by showing consciousness of guilt or may improperly be used substantively by the jury when the inconsistencies concern inculpatory facts). See also Hoffman, The Privilege Against SelfIncrimination and Immunity Statutes: Permissible Uses of Immunized Testimony, 16 CRIM. L. BULL. 421, 443-50 (1980).

On the other hand, impeachment use of a statement much less significantly affects the defendant's rights than does direct use of the statement.

227. Where a defendant must choose between testifying in order to establish standing under the fourth amendment, later facing impeachment with that testimony at trial, and remaining silent and forgoing his fourth amendment claim, Professor LaFave argues he has been " 'compelled' in the Portash sense." Professor LaFave thus contends that impeachment with such testimony is prohibited by the direct holding in Portash. 3 W. LAFAVE, SEARCH AND SEIZURE $\S 11.2$. at 243-44 (1985 Supp.).

This argument is not supported by the Court's analysis. The Court has drawn a clear distinction between direct, external penalties in the form of contempt or economic sanctions and consequences within the litigative process, which may or may not impermissibly burden the rights involved depending upon a balancing of interests. Only the former involves compulsion as used in Portash.

228. Of course, "compulsion" from operation of the rule may have no impact upon a particular defendant's course of conduct. He may choose to present any defense or no defense for reasons overpowering any fear of incrimination or impeachment. 
be used derivatively by the government, he would not be deterred from revealing his most appropriate defense. If he were torn between three possible options, for instance-alibi, self-defense, and no defense-and he were assured that the deposition would be used only to impeach his testimony if he took the stand, he would give notice of his most likely defense that involved his testimony rather than his silence. By providing discovery, he would retain his option to present his best defense or no defense at all, without immediate adverse consequence.

In providing discovery, the defendant renders his defense less effective because the deposition may be used to impeach his testimony. Any defense that requires the defendant's testimony is subject to such impeachment. As a result, while the threat of impeachment may cause the defendant not to present any defense at trial rather than one entailing his testimony, it slould not influence either his choice between the defenses requiring deposition or his decision to provide a deposition for his most likely defense. Accordingly, providing the statement imposes a costless burden at the deposition stage. The defendant's choice among defenses should reinain unaffected at this stage. ${ }^{229}$

In practice, the rule will cause all defendants with any plausible cliance of testifying to respond in one way: by providing the deposition. Only a defendant failing to comply with the discovery requirement will suffer a penalty. The fact that all defendants who might reasonably testify will respond identically hardly establishes that the rule entails no compulsion. Rather, it indicates that the compulsion operates in a single direction.

At the trial stage, the defendant's choice will no longer be even relatively unencumbered. ${ }^{230}$ Because he has been required to give that earher version of his testimony, he can be impeached if his testimony now differs. Essentially, a defendant inust either present no defense - to avoid impeachment - or present the same defense covered by the deposition. Even though no longer the most appropriate defense, the original defense may be the most viable since any alternative will be impeached. In some cases, variations even in minor details could prove critical in

229. If the hypothetical rule requires a deposition only as to some defenses, then the deposition requirement may affect the choice of defense even at an early stage. By choosing a defense that requires a deposition, the defendant restricts his ultimate choice either to that defense or to silence at trial. By contrast, if he chooses other defenses that have no deposition requirement, he retains his options to present that defense, any other defense without a deposition requirement, or no defense.

For example, if a defendant's statements to government psychiatrists relevant to the insanity defense were admissible to impeach his later testimony if he were to present another defense, marginal insanity defenses might be deterred. This is because all other defenses except alibi require no "statement" by the defendant and even an alibi defense entails a much less extensive "statement." By choosing any defense other than insanity, he would retain much greater freedom of action.

230. If at the end of the government's case the defendant decides independently that he does not wish to present any defense, then the rule will have had no effect. 
causing a defendant to remain entirely silent. For defendants who would choose to present a different defense, the threat of impeachment with the deposition would decisively discourage that course of action.

Thus, operation of the rule will result in some defendants' giving testimony at trial that is not the result of their "unfettered choice." Moreover, courts cannot alleviate this burden on an individual basis after determining the actual impact of the rule. The nature of the defense actually presented will not clearly signal whether free choice has been affected. A decision to present the same defense covered in the deposition or no defense inay be the product either of unconstrained choice or of fear of impeachment.

Is it a fifth amendment violation to impeach the defendant with his pretrial statement under the state's discovery rule or to allow the rule's operation to alter his choice of defense? Though the state applies no direct compulsion to a defendant's decision to give the deposition, its rule can impose substantial burdens that in some circumstances would violate the fifth amendment. Under the second inodel of compulsion, the rule has a substantial impact upon the policies behind the fifth annendment. It requires a defendant to speak and permits the state to use that speech to help convict him by impeaching his testimony. ${ }^{231}$ Also, possible use of the statement may influence both his choice to present any defense and his choice of which defense to present.

Nor does the rule operate independently of the fifth anendment, only incidentally affecting its concerns. Where, as here, the rule authorizes impeachment, the state's explicit purpose is to obtain information from the defendant to better convict him. ${ }^{232}$ Second, the defendant's response can hardly be construed as a strategic decision serving his own litigative interests; the disclosure provides him no benefit other than preserving a right to testify, which would not be at risk but for the stateimposed rule.

The discovery rule thus impinges upon the interests protected by the privilege against self-incrimination. The ouly remaining possibility for the rule's validity is to be supported by a sufficiently substantial state interest. The state has distinct interests at stake in three separate types of factual patterns: (1) a change of defenses that permits inadequate state investigation, (2) a change of defenses that demonstrates willful deception by the defendant, and (3) a change that is consistent with inistake or

231. Portash, Miranda, and Innis, see supra text accompanying notes 225-26 and note 226, tell us at least that the impeachment use of a statement is not irrelevant to the interests protected by the fifth amendment.

232. Because the prosecutor cannot have access to the deposition until the defendant testifies, the only possible purpose of the rule is to impeach. All other uses, such as avoidance of surprise and delay, are rendered untenable by the restriction upon prosecutorial access. 
uncertainty. The first two of these situations are easily assessed: the substantial state interest in each situation adequately supports use of the deposition for impeachment. The third situation presents a set of coinpeting interests whose resolution is unclear. I argue that in those circumstances impeachment use would violate the fifth amendment. ${ }^{233}$

\section{State Interests in Impeachment \\ a. Impeachment as a Remedy to a Change in Defenses That Permits Inadequate State Investigation}

When the defendant changes his defense from that for which he has given notice, he may thwart the state's interest in avoiding surprise. If the defendant waits until trial to substitute defenses that are materially inconsistent, he will often place the state in the same position it would have occupied had he provided no notice at all. Any sanctions properly imposed for a failure to give notice should be available here, and impeachment with the change of defenses is appropriate as a lesser sanction than preclusion of the entire defense. ${ }^{234}$

When, however, the defendant changes his defense in sufficient tine to permit the state to investigate and prepare for his new defense, the interest of the state is fully protected. In this situation, a rationale based

233. Williams does not directly address the issue in any of these situations. The Court docs suggest approval of impeachment in at least some circumstances, specifically, where a discovery rulc required the defendant to make an irrevocable pretrial choice of defenses.

[W] are simply not confronted with the question of whether a defendant can be compelled in advance of trial to select a defense from which he can no longer deviate. We do not mean to suggest, though, that such a proeedure must necessarily raise serious constitutional problems. See State ex rel. Simos v. Burke, 41 Wis. 2d 129, 137, 163 N.W.2d 177,181 (1968) ("[i]f we are discussing the right of a defendant to defer until the moment of his testifying the election between alternative and inconsistent alibis, we have left the concept of the trial as a scarch for the truth far behind").

399 U.S. at $84-85$ n. 15 .

This statement has two possible interpretations. First, Simos cites another state case, Statc v. Kopacka, 261 Wis. $2 \mathrm{~d} 70,51$ N.W.2d 495 (1952), which upheld the right of the trial court to prohibit the introduction of a different alibi than the one for which pretrial notice had been provided. Reading this opinion into the Williams quotation is not a startling interpretation. Where the state's rule requires notice of alibi, to the extent the defendant wants to rely upon an alibi defense, he "cannot deviate" from the one selected in advance by substituting one for which no notice was given.

Second, Simos expresses the position that the fifth amendment protects only "the right of a defendant to testify truthfully in his own behalf." 41 Wis. $2 \mathrm{~d}$ at 137,163 N.W.2d at 181. Again, it would be reasonable to interpret the Court's Williams comment in this light. That sentiment and the Court's position in Harris v. New York, 401 U.S. 222, 225 (1971) (The privilege "to testify in his own defense, or to refuse to do so ... cannot be construed to include the right to commit perjury."), share a common theme: To aid in finding the truth, the state should be able to confront a testifying defendant with his prior statements.

234. Note, The Preclusion Sanction-A Violation of the Constitutional Right to Present a Defense, 81 YALE L.J. 1342, 1358-59 (1972); see discussion of State v. Kopacka, 261 Wis. 2d 70, 51 N.W.2d 495 (1952), at supra note 233. 
on a change in defense cannot justify impeachment with the defendant's initial deposition.

\section{b. Impeachment as a Remedy for Willful Deception}

A defendant nray change defenses in a number of different situations, thus creating conflicts between the deposition and potential trial testimony. Four likely explanations exist: (1) the defendant lied in his pretrial deposition and wishes to tell the truth (or another he) at trial, (2) lie told the trutl in the deposition and wishes to lie at trial, (3) he was mistaken in his deposition and wishes now to tell an accurate story, and (4) his defenses are ambiguous. ${ }^{235}$

Related decisions indicate that the Supreine Court would uphold impeachment in at least the first two situations described above. In United States v. Knox ${ }^{236}$ and United States v. Kahan, ${ }^{237}$ tlie Court used somewhat different rationales to hold fifth amendment protections unavailable when a defendant provides willfully false statements. In Kahan, the defendant argued that Simmons $v$. United States ${ }^{238}$ prohibited use during trial of statements by him at a prior mdigency imquiry. The Court found Simmons inapposite because Kahan clearly knew that his representations were false at the time he made them. As such, there was no basis to protect them as necessary to litigate a claim lie beheved to be valid. ${ }^{239}$ In Knox, the Court held that though a professional gam-

235. The first two explanations are easy to understand; the last two would be helped by examples. An initial alibi deposition might be innocently inaccurate. A defendant, who we assume is innocent, knows he was not at the scene of the crime and, at the time of the deposition, believes he was at home with his family. Later, he recalls that he was elsewhere and submits an amended notice.

Insanity and self-defense illustrate ambiguous defenses. A person with mental problems is charged with a homicide. He may have been delusional at the time of the killing, reasonably feared for his safety, acted with some degree of justification, or committed the murder with intent to kill. Depending on his mental state, these defenses may be ambiguous.

236. 396 U.S. 77 (1969).

237. 415 U.S. 239 (1974).

238. 390 U.S. 377 (1968), discussed supra at text accompanying note 99.

239. Kahan, 415 U.S. at 243.

The Court based its opinion in part on the rationale that the statements were not testimonial since they were introduced to show the defendant's knowledge of their falsity rather than for their incriminatory content. The Court's subsequent decision in Estelle v. Smith, 451 U.S. 454, 463-64 (1981), undermines this rationale. But cf. South Dakota v. Neville, 459 U.S. 553, 561 (1983) (in dictum, Justice O'Connor notes the appeal of characterizing defendant's statements as real evidence). In his dissent in Kahan, Justice Marshall agreed that, just as willfully false statements could be used in prosecutions for perjury or false statement, they could be used in the defendant's pending trial. He concluded, however, that the trial court had not made the required finding of willful falsehood. Kahan, 415 U.S. at 247-49 (Marshall, J., dissenting). See also Columbia Note, supra note 110, at 690-93 (arguing that Justice Marshall's dissent would properly resolve the competing values).

The Court's subsequent decision in United States v. Apfelbaum, 445 U.S. 115 (1980), provides a more defensible basis for the result in Kahan. This rationale, too, accords with Marshall's position that the government can use a perjured statement for its incriminatory content on a substantive 
bler may refuse to incriminate himself by filing a wagering tax return, if he chooses to file a false return he can be prosecuted for that false response: "[W]hen Knox responded to the pressure under which he found himself by communicating false information, this was simply not testimonial coinpulsion."240

When the responses indicate that the defendant intends to commit perjury at his trial or has hed in his deposition, impeachment is justified. ${ }^{241}$ Either the defendant has forfeited his privilege by a willfully false response before trial, or he will perjure himself at trial, raising legitimate concerns for the integrity of the fact-finding process. ${ }^{242}$

offense. In Apfelbaum, the Court concluded that at the time the defendant was granted immunity before the grand jury he was faced with only a " 'trifing or imaginary' hazard of compelled selfincrimination as a result of the possibility that lie might commit perjury during the course of his immunized testimony." 445 U.S. at 131-32. Since an honest response would not incriminate the defendant, he had no fifth amendment protection against incrimination resulting from perjury. Apparently, the logic of this position means that if the government slows that the statement was perjured, the government can use the statement to show the defendant's conseiousness of guilt without violating his fifth amendment privilege. The danger that the defendant would commit perjury during his testimony does not raise a sufficiently substantial prospeet of incrimination to invoke the privilege. See generally Hoffman, supra note 226.

240. Knox, 396 U.S. at 82; see also Umited States v. Wong, 431 U.S. 174, 178-79 (1977).

With Kahan, Knox, and Apfelbaum, the Court used three separate rationales to hold willfully false statements outside the privilege against self-incrimination. In these different contexts, the Court found the statement not testimonial, not compelled, or not incriminating. Apparently, the Court has decided that perjured statements will not be protected by the fifth amendment, and it will find a rationale to support that result.

241. It is not clear that every false discovery response should forfeit fifth amendment proteetion and permit impeachment. Where the discovery mechanism is not a deposition taken under oath but is merely an unsworn response to government counsel, the trial is not directly threatened with "pollution" by perjury. Furtliermore, logistical difficulties inherent in determining when impeachment is appropriate could render impeachment problematic. The difference between a purposefully false response and an innocent mistake can be difficult to determine, and it may be even harder to ascertain whether trial testimony is perjurious or simply a correction of the false prior notice.

On the other hand, if one of the two statements is unquestionably a willful falsehood, the defendant has little equity to his argument that the the state should bear the burden of proving that such falsehood occurred at trial. Given the Court's strong commitment against the use of constitutional rights as a license for perjury, it is unlikely the Court will be solicitous of a defendant's argument that the task of showing that the lie occurred before trial is too onerous. Even if the defendant could prove this claim, the Court is unlikely to forbid impeacliment.

242. The facts underlying Commonwealth v. Alicea, $498 \mathrm{~Pa}$. 575, 449 A.2d 1381 (1982) provide a good example. Prior to trial, the defendant gave notice of alibi and at trial testified that he committed the homicide in self-defense. The state supreme court held that, sinee it was unclear that the defendant had lied at trial rather than in lis notice of defense, the trial court was not authorized, without more, to increase his sentence on the basis of perjured trial testimony. As the dissent observed, id. at 587 n.5, 449 A.2d at 1388 n.5 (McDermott, J., dissenting), the state should have been permitted to impeach him with the prior, willfully false statement.

While willful misstatements of a defense may not necessarily indieate conseiousness of guilt, they support impeachment. In State v. Williams, 121 Ariz. 218, 221-22, 589 P.2d 461, 463-64 (1979), the state supreme court reversed on the trial court's exclusion of evidenee of the victim's consent in a rape case for laek of notice required by the statute. The supreme court concluded that the state had not been prejudiced in its preparation, since it would necessarily prove lack of consent 


\section{c. Impeachment Justified Solely as a Relevant Prior Inconsistent Statement}

Beginning with Harris v. New York, ${ }^{243}$ and continuing with Oregon v. Hass, ${ }^{244}$ United States v. Havens, ${ }^{245}$ and Jenkins v. Anderson, ${ }^{246}$ the Supreme Court has repeatedly authorized impeachinent of a defendant's testimony with suppressed or constitutionally suspect evidence. These cases suggest approval of impeachment on the simple basis that use of the prior inconsistent statements enhances the truth-seeking process. In Harris, the Court emphasized that while the defendant has a right not to testify, "[h]aving voluntarily taken the stand, [he is] under an obligation to speak truthfully and accurately .... The shield provided by Miranda cannot be perverted into hicense to use perjury by way of a defense, free from the risk of confrontation with prior inconsistent utterances."247 With Jenkins the Court took this logic even further. It recognized that inpeachment with prearrest silence inay "burden" a suspect's right to remain silent, yet found that burden permissible. Once the defendant decides to take the stand, " " $t]$ he interests of the other party and regard for the function of courts of justice to ascertain the truth become relevant, and prevail in the balance of considerations determining the scope and limits of the privilege against self-incrimination." "248

Another arguably analogous situation is inpeachment use at trial of testimony elicited at a suppression hearing. In Simmons v. United

as part of its own case, and held preclusion of the defendant's evidence improper. It stated that, without condoning the failure of defense counsel to disclose the new defense, it could understand why counsel might have been misinformed by the defendant.

[W] can visualize a situation where a person, such as appellant, may lie to his attorney and not tell the truth in prior court hearing because he is afraid he will never be believed. If then, at trial, he finally tells his attorney the truth, absent prejudice to the state, the defendant should not be precluded from presenting his defense.

121 Ariz. at 221,589 P.2d at 464.

The court's analysis is appropriate in determining that preclusion of defense testimony is not the proper sanction. This rcasoning does not justify, however, preventing the prosecution from impeaching the defendant with his prior willfully false statement. Use of the evidence to impeach is a fair price to exact if the defendant chooses to take the stand since the probabilities are heavily against a totally innocent explanation of his prior statement. Impeachment will be justified in the vast inajority of cases.

243. 401 U.S. 222 (1971).

244. 420 U.S. 714,722 (1975).

245. 446 U.S. 620 (1980).

246. 447 U.S. 231,240 (1980).

247. Harris, 401 U.S. at 225-26.

248. Jenkins, 447 U.S. at 238 (quoting Brown v. United States, 356 U.S. 148, 156 (1958)); see also Stein v. United States, 346 U.S. 156, 177 (1953) ("The Constitution safeguards the right of a defendant to remain silent; it does not assure him that he may remain silent and still enjoy the advantages that might have resulted from testifying."); Note, supra note 83, at 305 (state's right to cross-exainine predominates over defendant's fifth amendinent interests where he has affirmatively benefited from his testimony and accordingly placed the state in a less advantageous position). 
States, ${ }^{249}$ the Court held that the defendant's testimony given on a motion to suppress evidence on fourth amendment grounds could "not thereafter be admitted against him at trial on the issue of guilt."250 Subsequently, in United States v. Salvucci, ${ }^{251}$ though the Court declined to decide explicitly whether testimony from a suppression hearing could be used to impeach, it suggested such would be proper. It stated: "This Court has held that 'the protective shield of Simmons is not to be converted into a license for false representations ... ." "252 Furthermore, the lower federal and state courts substantially agree that the Harris rationale apphies to Simmons and permits impeachment with the statement inade by the defendant at a suppression hearing. ${ }^{253}$

These cases appear to provide impressive support for the validity of impeachment with discovery disclosures. Their analysis loses its force, however, in the discovery context. The state's interest in pretrial discovery is insufficient to overcome the adverse impact on a defendant's fifth amendment interests. ${ }^{254}$ Curtailing a defendant's fifth amendment rights must be justified exclusively on the basis that he will present the

249. 390 U.S. 377 (1968).

250. Id. at 394.

251. 448 U.S. 83, $93-94$ (1980).

252. Id. at 94 n.9 (quoting United States v. Kahan, 415 U.S. 239, 243 (1974)).

253. United States v. Quesada-Rosadal, 685 F.2d 1281, 1283 (11th Cir. 1982); People v. Douglas, 66 Cal. App. 3d 998, 1003-06, 136 Cal. Rptr. 358, 361-63 (1977); State v. Vega, 163 Conn. 304, 306 A.2d 855 (1972); State v. Foraker, 446 A.2d 1105 (Del. 1982); People v. Sturgis, 58 Ill. 2d 211, 317 N.E.2d 545 (1974), cert. denied, 420 U.S. 936 (1975); Gray v. State, 43 Md. App. 238, 245, 403 A.2d 853, 858 (1979); State v. Buckley, 171 Mont. 238, 243-44, 557 P.2d 283, 286 (1976); State v. Bracey, 303 N.C. 112, 120, 277 S.E.2d 390, 395-96 (1981), Nelson v. State, 607 S.W.2d 554 (Tex. Crim. App. 1980); cf. State v. Boyd, 128 Ariz. 381, 625 P.2d 970 (Ct. App. 1981) (probation revocation testimony may be used for impeachment); People v. Coleman, 13 Cal. 3d 867, 533 P.2d 1024, 120 Cal. Rptr. 384 (1975) (probation revocation testimony may be used for impeachment); Ibn-Tamas v. United' States, 407 A.2d 626 (D.C. 1979) (testimony at prior mistrial may be used to impeach). But see Commonwealth v. Bertram, 596 S.W.2d 379 (Ky. Ct. App. 1980) (under state constitution, testimony at suppression hearing may not be used to impeach trial testimony); $c f$. United States v. Brown, 699 F.2d 585, 588-92 (2d Cir. 1983) (pretrial statements taken in violation of right to counsel may not be used for impeachment); United States v. Nussen, 531 F.2d 15 (2d Cir. 1976) (suppression hearing statements may not be used to impeach testimony of alibi witnesses), cert. denied, 429 U.S. 839 (1976); United States v. Trejo, 501 F.2d 138 (9th Cir. 1974) (illegally obtained evidence may be used to impeach only when focused on the truthfulness of defendant's direct testimony); People v. Chavez, 621 P.2d 1362, 1366-67 (Colo.) (testimony by defendant at trial may not be used to impeach at sentencing hearing), cert. denied, 451 U.S. 1028 (1981); Blaisdell v. Commonwealth, 372 Mass. 753, 762-63, 364 N.E.2d 191, $197-98$ (1977) (statements from courtordered mental exam may not be used for impeachment (dictum)); People v. Bland, 52 Mich. App. 649,218 N.W.2d 56 (1974) (statements made in physician-patient relationship may not be used for impeachment); Franklin v. State, 606 S.W.2d 818 (Tex. Crim. App. 1978) (suppression hearing silence may not be commented upon at trial).

254. One of the very few cases that has prohibited impeachment use outside of the pure compulsion situation involved a withdrawn discovery notice. In United States v. Leonard, 609 F.2d 1163 (5th Cir. 1980), the court held that where a defendant withdrew his insanity defense notiee after submitting to an examination by a government psychiatrist his trial testimony could not be impeached with his inconsistent statements to the psychiatrist. Without clearly articulating a theory, 
same information shortly and the state should have an adequate opportunity to prepare without delaying the trial. The state can have no legitimate interest in simply changing the balance of advantage between the two sides by making the defendant's testimony more vulnerable to attack through prior inconsistent stateinents. Such skewing would violate not only the pohicies behind the fifth anendment ${ }^{255}$ but those underlying the due process clause as well. ${ }^{256}$ A state inay be able to require a defendant to provide an early statement of his defense ${ }^{257}$ as a neutral mechanism to improve fairness and efficiency in higation. But it would destroy the legitimacy of the discovery procedure if the state used such statements to help convict the defendant since they may include misstatements occurrimg solely because the defendant was required to speak at an early moment. ${ }^{258}$

the court found the result necessary to prevent infringement of the "defendant's Fifth Amendment rights." Id. at 1166.

255. Garner v. United States, 424 U.S. 648, 655-56 (1976); Murphy v. Waterfront Comm'n, 378 U.S. 52, 55 (1964).

256. See Wardius v. Oregon, 412 U.S. $470,474-75$ (1973).

257. If the goal is honesty, an early response may be the most valuable because the defendant would not yet have perfected his fabrication. If the goal is accuracy, however, an early response will be the most inaccurate because defense investigation and preparation of the case is not yet complete.

258. Take the example of a defendant who provides a notice of alibi that he was at a given location at the time of the crime. He later uncovers a witness or documentary evidence that he was at another location. If he promptly provides notice of that later alibi, there is neither clear indication of willful falselıood nor independent justification for impeaclment. Impeaclıment provides unfair advantage to the state because, absent the discovery rule, the defendant would not "go on the record" before trial.

Consider three responses to this argument. First, people are unlikely to be honestly in error concerning their defense. A simple test slows the error of this claim. Ask yourself where you were at 6:00 p.m. last Tuesday witlout clecking any records. Then imagine that like most people who are charged with crimes, rather than those who read law review articles, you have no records and frequently live an unregimented life. Also assume, as often liappens when an mdigent defendant is represented by appointed counsel, that your attoruey speaks to you only once or twice about the alibi and expects you to do all the investigation concerning it. You will quickly see how the honest, innocent defendant simply trying to provide notiee of his true wlereabouts will often be in error. Ironically, innocent defendants may be more likely to be uncertain about their alibi than guilty ones. See Tucker, True Confessions: The Long Road Back from Miranda, NAT'L Rev., Oct. 18, 1985, at 29 (recounting the teclinique of a highly successful detective who began his investigation with the person who had the best alibi: “'The average person doesn't know precisely where he was every minute of the day .... It is only someone who has carefully rehearsed lis whereabouts who is likely to have a good story.' ").

Second, the error can be explained and therefore it does little liarm for the state to impeach the defendant with the inconsistency. On the contrary, the very use of the statement refutes this claim. If impeachment would do no harm, the state would not do it. See discussion of Innis and Miranda supra at note 226. Furthermore, jurors may remain unconvinced of the difficulty of remembering accurately. For example, no doubt some readers have been unwilling to accept that innocent defendants frequently will not recall initially where they were at the time of the crime.

Finally, I offer data, anecdotal to be sure, from my seven years of criminal defense work. Three of my clients were proven innocent througl accidental events and charges were dismissed by the government which was convinced to a moral certainty of their innocence. All three told me that they were not at the scene of the crime, as was clearly correct. My assessment was that only one of 
The fifth amendment argument against allowing the state to impeach with discovery disclosures is admittedly less formidable than the argument against direct use. It rests on the premise that, when conscious lies and abuses of the system are eliminated, the state has no legitimate justification for obtaining a litigative advantage against the defendant. Any such use offends the interests underlying the fifth amendment.

One counter-argument is that the danage to the policies behind the fifth amendment is de minimis. The inpairment is indeed considerably less than when direct use of the disclosure is mvolved; a credible argument can be made that the impairment does not rise to a constitutional level. Impeacliment may be poorly justified on policy grounds without being unconstitutional. A second argument is that the administrative difficulties in distimguishing willful falsehoods from innocent mistakes would make the system of litigation unworkable. ${ }^{259}$ This argument lias some limited validity; however, the question remains of how much weight to accord it agamst the constitutional concerns. Finally, sinply as a matter of prediction, the present Supreme Court is unlikely to draw the line suggested here. Motivated by a profound distaste for the possibility of perjury escaping undetected, it has already elminated most limitations agamst impeacliment in prior case law. ${ }^{260}$

Supreme Court propensities aside, I contend that each of these counter-arguments is insufficient to overcome a clear lack of justification for a practice that intrudes in a significant manner upon the fifth amendment. Each of the Court's expansions of impeachment, with corresponding restrictions on the fifth amendment, has been very attractive at some level. The same is true with discovery developments. The sum total, lowever, has had a profound inpact on the balance of advantage in criminal litigation. The Court's observation im Boyd v. United States ${ }^{261}$ is entirely apt liere: a constrained reading of the fifth amendment results ultimately in its incremental demise.

\section{Additional Issues Raised by Uses Beyond Impeachment}

In the preceding hypothetical, the defendant was required to give a deposition that could be used for impeachment but was assured that it would not be used in the state's case-in-chief. The inechanism I sug-

the three actually remembered where he was. Worse yet, my investigation uncovered nothing that, in my opinion, would have proved the alibi of any of the three to the satisfaction of skeptical jurors.

259. The trial court would presumably make such a determination without jury involvement. See FED. R. EviD. 104(a). Currently, as part of sentencing, judges determine that a defendant's testimony "contained willful and material falsehoods" without great apparent difficulty. United States v. Grayson, 438 U.S. 41, 55 (1978). Probably the greater practical issue is whether judges would make the finding too readily and vitiate any real protection for the defendant. See id. at 54.

260. See infra notes 395-99.

261. 116 U.S. 616,635 (1886); see supra note 8. 
gested-taking the deposition outside the presence of the prosecutor and sealing it until the defendant takes the stand-would effectively assure such protection. The problem is that this mechanism would undermine the purpose of discovery, that is, to avoid surprise to the prosecutor and to permit preparation of rebuttal. ${ }^{262}$

The hypothetical might be changed so that the deposition was made available to the prosecution from the beginning of trial but limited expressly to impeachment use. But then the previously discussed inherent conflicts between administrative feasibility and effective protection against misuse would arise. ${ }^{263}$ Without effective assurance against misuse, if the disclosure may reasonably mcriminate the defendant, not only are his fifth amendment protections insufficient but his choice to give the deposition would be strongly affected. He would not be free even at the deposition stage to preserve his most appropriate defense. In the face of potentially mcriminating disclosure, a defendant would withhold notice of his defense out of fear of its use beyond impeachment. The defendant would give notice only if his need for the defense were great enough to outweigh fear of incrimination.

As a result of the discovery rule, some defendants would either choose an inappropriate but less mcriminating defense or present no defense at all. Others with an incriminating but essential defense would not be similarly deterred. They would, however, be forced to pay the extra price of incrimination to present their defense. Tlus, in a real world discovery situation where the prosecutor has discovery information from the beginning of the case and where the disclosure may reasonably be used to prove guilt, impeachment use of discovery would only add to the unconstitutionality of direct or derivative use of discovery. When, however, the type of information discovered is not likely to incrimmate the defendant, impeachment use alone will determine its validity. Discovery of the alibi defense illustrates this point. An alibi is not directly incriminating, but its discovery may violate the fifth amendment under my analysis if an anended or witlidrawn notice is used to impeach the defendant when he has neitler abused the discovery process nor provided a willfully false response. ${ }^{264}$

262. See discussion of Radford v. Stewart, 324 F. Supp. 826 (D. Mont. 1970), aff'd, 472 F.2d 1161 (9th Cir. 1973), supra note 214. The case demonstrates how the prosecution may avoid the possibility of misuse of discovery, but the necessary safeguard renders the discovery rule useless for its intended purposes. Radford does not provide a justification for the rule; rather, it shows that if the rule operates consistently with the fifth amendment, it cannot achieve its stated purposes when the required disclosures could incriminate the defendant.

263. See supra text accompanying notes 212-21.

264. In states holding the use of discovery statements valid under the fifth amendment, use of counsel's statements must overcome a second protection-the attorney-client privilege. Typically, assertions of the privilege are brushed aside with a passing reference to the doctrine of waiver. Waiver is premised upon the voluntary disclosure, during discovery, of information to a party 


\title{
4. State Use of Discovery Statements to Impeach the Defendant
}

\author{
Nonetheless, a number of states permit discovery disclosures to be
}

outside the confidential relationship. See, e.g. United States v. Bump, 605 F.2d 548, 551 (10th Cir. 1979); State v. Howell, 56 Or. App. 6, 10, 641 P.2d 37, 39 (1982); State v. Gay, 6 Utah 2d 122, 124, 307 P.2d 885, 885-86, cert. denied, 355 U.S. 899 (1957); State v. Dault, 19 Wash. App. 709, 716-18, 578 P.2d 43, 47-48 (1978).

Perhaps correct at some technical level, the analysis begs critical policy issues underlying the privilege. The error can best be understood by reference to the original justification for elimination of both the fifth amendment protections and the attorney-client privilege, Justice Traynor's decision in Jones v. Superior Court, 58 Cal. 2d 56, 61-62, 372 P.2d 919, 922, 22 Cal. Rptr. 879, 882 (1962). Justice Traynor concluded that, as to materials that the defendant would soon disclose at trial, the attorney-chent privilege was waived for the purpose of facilitating prosecutorial examination. Where the defendant knows he will reveal the information at trial, advancing the time of waiver is sensible. Where, however, the defendant is uncertain that he will reveal the information, there is no justification for forcing him to waive the privilege. A discovery statute requiring an uncertain defendant to provide the information or forfeit his right to testify and present evidence coerces waiver of his privilege.

Two accommodations are possible. First, the state may require disclosure only when the defendant is certain that he will present the confidential information at trial. Indeed, some authority supports the proposition that no more is required. State v. Marchellino, 304 N.W.2d 252, 254-55 (Iowa Ct. App. 1981) ("Witnesses 'expected' to be called" is subjective concept.); People v. Green, 83 Misc. 2d 583, 595, 371 N.Y.S.2d 271, 281-82 (Crim. Ct. 1975) ("If counsel for the defendant is genuinely undecided as to whether or not to introduce certain testimony, the court should refrain from imposing any sanctions on his failure to disclose under these circumstances."); 1969-70 ABA STANDARDS $\S 3.2$ commentary at 98; 1969-70 ABA STANDARDS $\S 3.3$ commentary at 5 (Supp. 1970); see also Blumenson, supra note 33, at 125, 139-50 (under due process, a defendant may be compelled only to provide discovery of evidence he presently intends to introduce at trial and not evidence he may potentially introduce). Most authorities, however, require the defendant to disclose all information that he may introduce. State v. Lindsey, 284 N.W.2d 368, 373 (Minn. 1979) ("Defense counsel cannot now justify his lack of disclosure by claiming that the decision to call these non-disclosed witnesses was not formally made until after the state had rested. Such an interpretation of the discovery obligation would render [the rule] meaningless . . . ."); State v. Cox, 542 S.W.2d 40, 50 (Mo. Ct. App. 1976) ("The Rule contemplates that the defendant be specific whether he will or will not assert the defense of alibi. It does not permit equivocation."); People v. Hampton, 696 P.2d 765, 776 (Colo. 1985) ("[O]nce the prosecutor serves a specification of time and place [under notice of alibi rule], then as long as the defendant is aware of the alibi defense and alibi witnesses and desires to preserve his option to present this evidence at trial, he is under a continuing obligation to [provide the required information] . . . within a reasonable time . . . " (emphasis added)); $c f$. Taliaferro v. State, 295 Md. 376, 395-96, 456 A.2d 29, 40 (strict enforcement of preclusion sanction for noncompliance with notice requirements necessary to enforce discovery rules so that trial disruptions and delay may be avoided), cert. denied, 461 U.S. 948 (1983).

The second possible accommodation is recognition that the privilege is waived only by the use of the evidence at trial and that the tentative disclosure for discovery purposes does not void the privilege. See infra note 345 . This approach departs from traditional waiver concepts which find waiver of the attorney-client privilege in any voluntary disclosure of confidential information. Id. Nevertheless, it is necessary to harmonize the state's interest in vigorously enforcing timely compliance with its discovery rules and the basic rationale of the waiver concept. Indeed, those who argue for strict notice requirements, enforced by forfeiture of the right to introduce evidence not disclosed, rely on the premise that the defendant suffers no irrevocable loss from compliance. Note, supra note 25, at 269-70, 273-74. A two stage concept of waiver is necessary for that premise to be correct. Only if revelation of the information at the first stage-discovery-does not waive the privilege is it accurate to say that the defendant is not prejudiced by being required to provide discovery. If, on the other hand, irrevocable waiver only occurs at the second stage-when the information is disclosed at trial for the benefit of thc defendant-discovery may properly be required. 
used to impeach the defendant when his trial testimony is inconsistent with his pretrial notice. ${ }^{265}$ These disclosures are clearly testimonial assertions under the fifth amendment, adinitted and utilized for their communicative content. Again, neither the fifth amendment nor the the-

265. Of the states permitting impeachment, few do so under express statutory authorizatiou. Only Pennsylvania explicitly authorizes impeachmeut in its discovery rules. PA. R. CRIM. P. 305(C)(1)(g) permits cross-exammation of the defendant with his notice of alibi when he has either failed to file a notice or gave information different from his subsequent testimony. Subsection (f) of the same rule prohibits the prosecution from commenting upon, or auy adverse inference being drawn against the defendant for, failure to call a witness listed in an alibi or iusanity notice unless he or his counsel attempts to explaiu to the jury the failure to call the witness.

At the other end of the spectrum, only two states explicitly prohibit such impeachment use. CONN. Super. CT. R. 768, 772; MASS. R. CRIM. P. 14(b)(1)(F). Most states fall betweeu these two extremes. A substantial number of states prohibit impeachment with the failure of the defense to call witnesses listed as supporting a specified defense. IDAHo CRIM. R. 16(h); MINN. R. CRIM. P. 9.02 subd. 4; N.Y. CRIM. Proc. LAW § 240.70(2) (Consol. 1982); OHIO R. CRIM. P. 16(c)(3); R.I. R. CRIM. P. 16(e); VT. R. CRIM. P. 16.1(c). Three states protect only against comment concerning alibi notice or alibi witnesses. ME. R. CRIM. P. 16A(b); MASS. CRIM. P. 14(b)(1)(F); N.M. DIST. CT. R. CRIM. P. 32(d). Typically these states make no provision for what, if any, use the prosecutor may make of required disclosures concerning the nature of defense and its details.

The pattern of little explicit authorization of impeachment but few specific restrictions upon use of discovery reflects the approach of the 1969-70 ABA Standards and the 1970 proposed Federal Rules, upon which most jurisdictions relied. The 1969-70 ABA Standards as originally proposed contained no provisions requiring the defeudant to specify the nature of his defense or provide the names and addresses of witnesses. Standard 3.3, which requires these disclosures, was added by amendment in the House of Delegates. See 1969-70 ABA STANDARDS § 3.3, at 3-6 (Supp. 1970). Even the amended standards were silent as to permissible prosecutorial use of the required disclosures. The 1970 proposed federal discovery rules, required no specification of defenses but did require a listing of defense witnesses. It prohibited prosecution comment upou the failure of the defense to call any listed witness. Proposed Rule 16(b)(3), 48 F.R.D. 553, 592, 609-10 (1970), 62 F.R.D. 271, 306, 316 (1974). By contrast, the federal discovery rules for alibi and insanity defenses as actually promulgated are much more protective of defense interests. FED. R. CRIM. P. 12.1(f), "Notice of Alibi," provides that "[e]vidence of an inteution to rely upon an alibi defense, later withdrawn, or of statements inade in connection with such intention, is not, iu any civil or criminal proceeding, adinissible against the person who gave notice of the intention." Rule 12.2(e) makes similar provisions for notices provided for the insanity defense.

Neither the alibi nor insanity mles, as sent to Congress by the Supreme Court, contained such limiting provisions, 62 F.R.D. at 292-93, 295, but Congress added this limitation before adopting the notice of alibi rule. In 1983, a similar provision was added to the insanity defense discovery rule. The Advisory Committee Note explaiued that the uew provision

insures that the notice requirement ... will not deprive the defendant of an opportunity later to elect not to utilize any expert testimony. This provision is consistent with Williams v. Florida ...., holding the privilege against self-incrimination is not violated by requiring the defendant to give notice of a defense where the defendant retains the "unfettered choice" of abandoning the defense.

97 F.R.D. 245, 296 (1983).

The 1978 ABA Standards reflect a similar set of restrictions concerning alibi and insanity, the only two defenses for which the new standards permit discovery. 1978 ABA STANDARDS $\S 11$ 3.3(b) provides, "Information disclosed pursuant to [this section] is not admissible in evidence at a hearing or trial." The commentary explains only that "[t] he provision has been added to ensure that the defendant who chooses not to call the named witness will not be penalized for changing strategy." 1978 ABA STANDARDS $§ 11-3.3($ b) commentary at 11-56. Few states have followed these more restrictive provisions, however. But see CoNN. SuPER. CT. R. 768, 772; MAss. R. CRIM. P. 14(b)(1)(F). 
ory upon which prosecutorial discovery is based justifies impeachment except when the state is prejudiced in its ability to investigate an altered defense, or when either the discovery disclosure or the trial testimony is willfully false. Under this analysis, impeachment, as permitted in a number of these states, is unconstitutional.

States that permit impeachment generally fall into three groups. One group views impeachment of the defendant with his response to discovery rules precisely like any other statement of a party or his counsel contrary to the position he takes at trial. The statement is considered an evidentiary adimission; ${ }^{266}$ the attorney-chent privilege is held to be waived because the disclosure is knowingly made to persons outside the scope of the confidential relationship; ${ }^{267}$ and the fifth amendment issue is seen as resolved by Williams $v$. Florida since the defendant has announced his intention to introduce the disclosed fact at trial. ${ }^{268}$

The second group of states permits impeachment as an appropriate sanction for abuse of mandatory disclosure rules. ${ }^{269}$ These states may authorize impeachment rather than preclude his testimony if the defendant fails either to file a notice of defense or to provide accurate details.

266. See supra note 160 .

267. See supra note 264 .

268. States following this basic analysis include:

MICHIGAN-People v. Nickopoulous, 26 Mich. App. 297, 302, 182 N.W.2d 83, 86 (1970) (prosecution allowed to introduce first of two alibi notices filed by defense counsel for impeachment purposes, applying general rule that party may be impeached with "a superseded pleading containing an admission against the interest of the pleader").

OHIO-State v. Sims, 3 Ohio App. 3d 321, 445 N.E.2d 235 (1981) (defendant may be crossexamined with failure to file alibi notice until eighteen months after arrest where notice was timely but had not been filed before two previous trial dates that were at the last moment postponed). But cf. State v. Sims, 3 Ohio App. 3d 331, 445 N.E.2d 245 (1982) (defendant may not be impeached with delay between the arrest and date of a timely filed notice of alibi if no prior trial dates have passed).

OREGON-State v. Howell, 56 Or. App. 6, 9-10, 641 P.2d 37, 38-39 (1982) ("Pretrial Disclosure" made during pretrial conference that listed "alibi" as defense properly used to impeach defendant's trial testimony in rape case that he had consensual sex with the victim).

TENNESSEE-State v. Meadows, 635 S.W.2d 400, 405 (Tenn. Crim. App. 1982) (impeachment with failure to call witness listed in defendant's notice of alibi permitted even though rule prohibits admission of "an intention to rely upon an alibi defense, later withdrawn, or of statements made in connection with such intention" because, unlike state's general discovery rule, this rule does not explicitly prohibit comment on failure to call a listed witness).

UTAH-State v. Gay, 6 Utah 2d 122, 123-24, 307 P.2d 885, 885-86 (defendant properly impeached with alibi notice stating that at time of crime he was at his grandparents' farm when he testified at trial he was at "his mother's place"), cert. denied, 355 U.S. 899 (1957).

269. While exact classification is dificult, the states falling into this category include:

ARIZONA-ARIz. R. CRIM. P. 15.4(c) provides that the prosecution cannot comment on information in notice of defenses and witness lists unless the court finds that "the inclusion of the witness' name or defense constituted an abuse of the applicable disclosure rule." The commentary to Rule 15.2, describing this provision, states cryptically: "Furthermore, the disclosure of a defense will not serve to alter the proceedings at trial." This language suggests that the discovery rules should not alter the defendant's choice of defense.

Apparently, this rule prohibits impeachment if the defendant changes his defense but the change does not prejudice the state's preparation. It is uncertain whether impeachment would 
Impeachment is treated as a less extreme penalty than preclusion and an appropriate sanction because it is more solicitous of the defendant's right to testify or present a defense. ${ }^{270}$

A third group of states does not permit impeachment at all. For soine the restriction is found in the language of the rule; ${ }^{271}$ for others it has constitutional underpinnings; ${ }^{272}$ for still others the basis is unclear. ${ }^{273}$ The courts in Montana and, to some degree, Illinois have correctly

constitute an abuse under the rule if the first notice was willfully false but the state's preparation was not hampered.

MINNESOTA-State v. Graffice, 294 N.W.2d 324, 326 (Minn. 1980) (prosecutor properly established that defendant omitted specific details of his alibi from pretrial notice because with adequate notice state could have interviewed person allegedly with defendant at time of crime). But see State v. Billups, 264 N.W.2d 137 (Minn. 1978) (in case tried before effective date of the alibi rule, questioning defendant concerning failure to reveal alibi prior to trial held improper under Doyle $v$. Ohio, 426 U.S. 610 (1976)).

PENNSYLVANIA-Pennsylvania by rule permits cross-examination of the defendant concerning the alibi notice where the defendant fails to provide any notice of alibi or testifies contrary to the notice provided. PA. R. CRIM. P. 305 (C)(1)(g). See supra note 265.

270. In Commonwealth v. Bey, 294 Pa. Super. 229, 439 A.2d 1175 (1982), however, the court used a much broader rationale. It approved impeachment of a defendant with discrepancies between his trial testimony and his alibi notice. The court found the questioning to be "valid cross examination" and "the risk a witness assumes when he takes the stand." Apparently, the defendant had argued that such impeachment went beyond the rule's purpose of permitting preliminary investigations by the state. The court rejected this limiting rationale, concluding that the procedures produced a fair trial in this case. Id. at 240-41, 439 A.2d at 1180-81.

WASHINGTON-State v. Acosta, 34 Wash. App. 387, 391-92, 661 P.2d 602, 604-05 (1983) (defendant properly impeached with change of defense-self-defense instead of alibi-where counsel did not notify court or opposing counsel of change in defense plans), rev'd on other grounds, 101 Wash. 2d 612, 683 P.2d 1069 (1984)(en banc). Acosta cited Dault, 19 Wash. App. 709, 718-19, 578 P.2d 43, 47-48 (1978), which authorized impeachment on the theory that the prior representation was "[a] 'quasi-admission [' of the client admissible to discredit and impeach the client's testimony." The Acosta court reached the same result but noted it "would state the rcasons somewhat differently"; it adopted the rationale that impeacliment is a proper sanction for failure to comply with discovery requirements.

The states in this second category, except perhaps Arizona, see supra note 268, have not clearly indicated whether they will permit impeachment where the notice is changed, but early enough that the prosecution can investigate adequately the merits of the defense case. If the defendant provides notice in time for state preparation, the rationale of lesser sanction cannot justify impeachment.

271. The rules of Connecticut and Massachusetts contain limiting language similar to that used in the federal alibi statute. CoNN. SupER. CT. R. 768, 772; MASS. CRIM. P. 14(b)(1)(F).

272. Missouri and Montana have given a constitutional basis to the restriction:

MISSOURI-In State v. Curby, 553 S.W.2d 566, 568-69 (Mo. Ct. App. 1977), the court held it improper for the prosecutor to alert the jury that the defendant provided a notice of alibi but his counsel's opening statement presented a new defense. The state court, citing Williams, rejected the argument that once the defendant has provided notice of alibi he may not shift to another defense. The Missouri rules do not require specification of all defenses. Therefore, a defendant may abandon his alibi defense, which he must specify, and present a number of other defenses without violating any independent notice requirement. In Curby, the state court of appeals used constitutional principles to prohibit prosecutorial use of the notice of an abandoned alibi defense.

In State v. Brooks, 567 S.W.2d 348, 352-53 (Mo. Ct. App. 1978), the defendant delayed filing a notice of alibi until shortly before the trial date. The notice was accepted and the trial delayed, presumably to enable the prosecutor to investigate the alibi. The court found improper the prosecutor's cross-examination of the defendant for not providing a notice of alibi until the eve of 
identified the reason for generally prohibiting impeachment of a defendant with his discovery disclosures. ${ }^{274}$ The purpose of discovery is to permit preparation by the state, not to lock the defendant into a specific defense. Also, states correctly permit impeachment as a remedy where the defendant abuses the rules, thereby preventing the state from adequately preparing for the defense. ${ }^{275}$ Failure to give adequate notice affects the quality of the opponent's case and justifies a remedy, such as

trial, citing the prohibition in Doyle v. Ohio, 426 U.S. 610 (1976), against impeaching a defendant with his post-arrest silence.

MONTANA-In State ex rel. Sikora v. District Court, 154 Mont. 241, 252, 462 P.2d 897, 903 (1969), the Montana Supreme Court emphasized the limited use of discovery under MONT. R. CRIM. P. $\S 46-15-301$ (2) (current version at MONT. R. CRIM. P. §46-15-323(3): "[The statute] very carefully uses the language 'For purposes of notice only and to prevent surprise ***' .... Such notice would in no way affect the defendant's presumption of innocence, nor would such information ever be available to the jury."

The court found that the statute prohibits direct use of the defendant's notice to establish his guilt because such use would violate the fifth amendment. The court also suggested that the statutc prohibits any direct use of the notice against the defendant. In State v. McKenzie, 186 Mont. 481, 500-01, 608 P.2d 428, 441, cert. denied, 449 U.S. 1050 (1980), the court explicitly prohibited direct use of an "insanity" notice:

It should be emphasized that the purpose of the statute is for notice, to prevent surprise, and to eliminate the necessity for a continuance of a trial when the defense is raised. The faet of notice does not amount to a plea, and it could not be used in any way as evidence in a trial on the merits. The provisions merely provide for advance notice of the intent to rely on such defense so that the State may be prepared to meet this defense.

(Emphasis added).

273. The Colorado Supreme Court recently decided, without clearly articulating the basis for its decision, that where a defendant decides not to offer alibi evidence at trial, he may not be impeached with his notice of alibi. People v. Hampton, 696 P.2d 765, 777 (Colo. 1985). The opinion may bc read to link the requirement that the defendant furnish notice of alibi before he is completely certain that he will utilize the defense with a prohibition against any use by the state of the notice where he decides not to offer alibi evidence at trial. See supra note 264 . The court did not rule whether impeachment would be permissible if the defendant offered an alibi that differed from the onc described in the notice.

In addition, Illinois prohibits impeachment on a theory that combines limitations to avoid unfair surprise and to permit adequate prosecutorial preparation without delaying the trial with language of the law of evidence suggesting that the disclosures should not be classified as admissions.

In People v. McFarland, 93 Ill. App. 3d 136, 142-43, 416 N.E.2d 769, 775 (1981), the court held improper cross-examination of the defendant with inconsistencies between his trial defense and the notice of intoxication defense. The court found no explicit restriction in the statutory language which authorized use of discovery materials for " 'the purposes of conducting his side of the case." See ILL. S. CT. R. CRIM. P. 415(c). It recognized that the purpose of discovery is "to prevent surprise or unfair advantage and to aid in the search for the truth." McFarland, 416 N.E.2d at 775. It emphasized that the selection of a defense was within the province of counsel, that it was subject to change, and that the requirement of disclosure of defenses to be used at trial was not intended to limit counsel's discretion in conducting the trial. On this basis, the court mled that the notice amounted only to tentative theories of counsel and were not admissions of the defendant.

This decision is indefensible on strictly evidentiary grounds. Even if tentative, a statement of counsel that reflects an affirmative statement of fact by the defendant constitutes an admission under traditional evidentiary analysis. See supra note 160 . On policy grounds of limited justification for discovery, the case is correctly decided, however.

274. See supra notes 272-73.

275. See, e.g., supra note 269, for discussion of Arizona rule. 
impeachment, which explains to the jury why the state's response is weak. $^{276}$

As developed above, not all discovery rules threaten the defendant's fifth amendment rights. Williams supports the constitutionahity of some, but not all, discovery rules. By carefully exainining the impact of such rules on the rights of the defendant and by applying the second model of compulsion, the limits imposed by the fifth amendment on discovery practices become clear.

Up to this point I have focused on the fifth anendment limitations on discovery practices, reflecting my evaluation of the fifth amendment as the most important and comprehensive source of protection available to the defense. The implications of expanded criminal discovery against the defense go further, however. In Part IV, I will examine other constitutional and statutory restrictions on discovery practices.

\section{IV}

\section{The Collapse of Other Doctrines Protecting DEFENSE CONFIDENCES}

One coininentator has described the fifth amendment, the attorneyclient privilege, and the work product doctrine as together creating a "shield of confidentiality" for the criminal defendant. 277 These three doctrines rest on somewhat different conceptual bases and provide sometimes overlapping and sonietimes unique protection agamst discovery by the prosecution. I will now turn my discussion to types of discovery to which the fifth amendment is largely or wholly inapphicable. Here the work product doctrine and the attorney-chent privilege, supported by the

276. As discussed earlier, several states, with little or no analysis, permit the prosecution to impeach the defendant at trial with notice of a since-discarded defense-as if it were a prior inconsistent statement. If lack of compulsion makes fifth amendment protections inapplicable to these disclosures, then the prosecution need not stop with impeachment but could use them in its case-in-chief.

For example, in United States v. McKeon, 738 F.2d 26 (2d Cir. 1984), the Second Circuit held that the government could use in its case-in-chief an opening statement made by the defense at a previous trial to show consciousness of guilt. The defense had carefully altered its subsequent opening statement to assert new facts compensating for changes in the government's evidence. The court found that the factual assertions of an attorney qualified as party admissions since he acted within the scope of his duties as defendant's agent. Under the facts of the case, circumstances corroborated the conciusion that the defendant provided the information himself.

Similar conclusions are generally warranted for many discovery representations. In the states permitting broad impeachment with discovery notices there is no articulated doctrinal reason why in a homicide case, for example, notice of self-defense should not be admissible to prove the defendant was the person who committed the killing. Such use of discovery to establish guilt would be clearly unconstitutional, however, as demonstrated in the first three hypotheticals. See supra text accompanying notes $125-221$.

277. Allis, supra note 1 , at 483 . 
sixth amendment right to effective assistance of counsel, offer the most important sources of protection.

During the 1970's, as courts and legislatures cut away critical fifth amendment protections at the center of the "shield," the work product doctrine and the attorney-client privilege might have retained their vitality. Instead, they too fell victims to general concepts of hitigative fairness applied in a vague and uncritical manner. As a result, states have diminished the protections for the criminal defendant under both these doctrines.

I will here describe and analyze those developments. I will focus on two areas where expansion of prosecutorial discovery has been most prevalent. These are the use of defense experts and, to a lesser degree, the statements of defense witnesses. In Section A, I address discovery of the identity and the reports of defense experts. In Subsection 1, I discuss the limited role of the fifth amendment, which arbitrarily protects defendants who act without counsel yet provides no protection for the represented defendant. I then turn, in Subsection 2, to the work product doctrine. Here I argue that the doctrine's basic purpose of protecting diligence and imıovation in litigation requires the invalidation of many developments permitting discovery of defense experts. Furthermore, prosecutorial use at trial of defense expert investigation iinplicates work product values where the prosecution learned of such investigation fortuitously rather than through fornal discovery. This is particularly so if such knowledge resulted either from the state's physical possession of the evidence or from the defendant's indigency. In Subsection 3, I argue that the sixth amendment right to effective assistance of counsel also forbids requiring the defense to disclose unsuccessful investigatory efforts that may incriminate. In Subsection 4, I describe a conditional concept of waiver, applicable both to work product and sixth amendment protections, that would permit discovery to proceed, but allow prosecutorial use at trial only if the defense actually follows through on its intent to introduce the witness or defense in question.

In Section B, I discuss the requirement in several states that the defense create statements of its own witnesses. Other states require the defense to provide the prosecution with statements it has created of prosecution witnesses, even if the defense does not use the statements to impeach adverse witnesses. I argue that these practices seriously threaten sixth amendment values.

In Section C, I examine prosecutorial use of the defendant's statements to defense experts used to prepare an insanity defense. Though such statements are within the ambit of attorney-client privilege, state courts have increasingly broadened the concept of waiver to the point of being triggered by the defense's decision to present an insanity defense. 
This development, if carefully limited to situations in which the prosecution has an extreme need to obtain and use the defendant's statements, is constitutionally acceptable but nonetheless disturbing. More serious constititional concern arises from expansion of the concept of waiver beyond situations of extreme need. The courts doing this justify expansion under a general notion of hitigative fairness. This expansion tendency seriously threatens the basic protections of the attorney-client privilege.

\section{A. Disclosure of the Identity of Expert Witnesses and Their Reports}

Preparing for trial, the defense inay generate expert opinions detrimental to its own cause if made available to the prosecution through unrestricted discovery. For example, assume that the defendant is charged with rape. He denies having had sexual intercourse with the victim. The victim's medical examination reveals the presence of neither hive sperin nor a foreign blood type. The prosecution requests no tests of the defendant. ${ }^{278}$ For defendant to estabhish that he did not commit the rape, defense counsel obtains court approval to hire an expert to perform tests on the detained, indigent defendant. The tests reveal that the defendant is sterile and that his blood type is not observed in his bodily fluids. As a result, his semen would contain neither live sperin nor any indication of his blood type. Naturally, the defense does not intend to introduce these tests at trial: they would lielp the prosecution by providing an explanation for the otherwise troubling absence of corroborating physical evidence. The issue is whether the state inay fornally discover these results and use them at trial, or whether the work product rule or constitutional doctrines prohibit such discovery and use.

\section{The Limited Scope of Fifth Amendment Protection}

The fifth ainendinent prohibits the state froin requiring our hypothetical defendant to disclose personally the hypotlietical tests yet would allow the state to obtain the saine disclosure from defense counsel. Because the fifth amendment apphies ouly to the defendant's own disclosures, its protections are of no practical consequence in the niajority of cases in which defendant's counsel is aware of expert investigations from sources independent of any confidential communication with his client.

278. The fifth amendment would not apply if the state had requested these tests, since the tests require no testimonial conduct by the defendant. Depending upon the procedures employed, however, the state may be required to justify the testing under the fourth amendment. See generally Schmerber v. California, 384 U.S. 757 (1966) (because not communicative, withdrawal of blood from defendant's body is outside protections of fifth amendment, but requirement that defendant submit to test and procedures employed must satisfy reasonableness standard of fourth amendment). 
Clearly, however, the defendant's interests in preventing disclosure are of equal importance whether represented by counsel or not.

Under Fisher $v$. United States, ${ }^{279}$ the prosecution cannot demand that the defendant produce the names and addresses and reports of experts he will not be imtroducing at trial. The fifth amendment prohibits a requirement, accompanied by the threat of a direct sanction for failure to respond, that he provide discovery of incrimmating information otherwise unknown to the state. The fifth amendment violation occurs when the defendant is required to reveal the existence of the incriminating information, not when he or others create it. ${ }^{280}$ Discovery from the defendant is prohibited whether or not he participated in the expert's effort and irrespective of the confidentiahty of the report's contents. ${ }^{281}$

In contrast to its protection against disclosure of expert investigation when the demand is directed to the defendant, the fifth amendment offers no protection from demands directed at defendant's counsel. ${ }^{282}$ It does not protect agamst such disclosures because the lawyer, not the defendant, is compelled to respond. The defendant is not personally subject to any compelled testimomial incrimination. Because the fifth ainendment allows discovery from counsel that cannot be had from the defendant, defendants without counsel or defendants who take personal charge of certam parts of the investigation have protections others do

279. 425 U.S. 391 (1976).

280. Id. at 410-11 (while contents of pre-existing, voluntarily created documents not protected by fifth amendment, act of producing them in response to governmental demand may be communicative and protected by privilege against self-incrimination).

281. For a general examination of these issues, see supra text accompanying notes 161-68.

282. While the fifth amendment offers no protection from discovery demands directed at defendant's counsel, it may suggest complimentary protection under a state's attorney-client privilege. In Fisher, the Court interpreted attorney-client privilege to protect information in the attorney's hands that would have been protected by the fifth amendment if retained by the defendant. See Mosteller, supra note 165 , at $86 \mathrm{n} .286$ (discussing application of attorney-client privilege operating in conjunction with Fisher's act of production doctrine). Such an interpretation would make no difference in our hypothetieal, however, since the attorney knows of the expert's finding without a confidential communication from the defendant.

Therefore, under established fifth amendment and attorney-client privilege prineiples, a statc could promulgate a rule that authorized discovery of scientific reports from the defense attorney unless she learned of the report through a confidential communication with her client or the reports were based on communications from the defendant. In People ex rel. Bowman v. Woodward, 63 III. 2d 382, 349 N.E.2d 57 (1976), the Illinois Supreme Court held that such a rule would be unconstitutional. Relying on Fisher, the court ruled that the state could not order the defendant to disclose all scientific tests regardless of his intention to introduce them at trial when the state did not know what tests existed. The court viewed the discovery demand as running directly against the defendant, even though the discovery rule and the trial court order were directed to defense counsel rather than to the defendant. The Illinois rule clearly contemplates discovery of test results from defense counsel. ILL. SUP. CT. R. CRIM. P. 413(c) (discovery permitted of reports or statements that "defense counsel has in his possession or control"). Neither the fifth amendment nor the attorneyclient privilege applies to test results obtained by counsel without the defendant's participation, whether or not the state knows which tests had been performed. 
not. But it is entirely without rational justification to shield one defendant's investigative efforts while denying protection to another. Accordingly, a doctrine other than the fifth amendment must provide ineaningful protection. ${ }^{283}$

\section{The Limited Scope of the Work Product Doctrine}

As prosecutorial discovery has been expanded, the work product doctrine has only weakly protected defense expert witnesses and their opinions. First, exphcit work product considerations have played hittle or no role in the formulation of formal discovery rules in those states that have broadly expanded prosecutorial discovery. Second, the work product doctrine, where exphicitly recognized as apphicable to discovery, has been narrowly defined as a limitation on what the prosecution may introduce at trial. I will argue that the values underlying the work product doctrine justify protecting the defense agamst expanded discovery of expert preparation not ultiniately introduced at trial.

The prosecution inay learn of defense experts either fornally through discovery or informally and fortuitously. In some states, discovery rules exphicitly address the right of the prosecution to learn the identity of defense experts: some of these states prohibit discovery, others permit it. Courts in two states have proscribed under their discovery rules discovery of the names or reports of experts whom the defense does not intend to call. ${ }^{284}$ On the other hand, rules in two states specifically authorize disclosure of expert reports, such as the hypothetical one. ${ }^{285}$ General discovery provisions in several other states also may be interpreted to permit such disclosure. Under these general provisions, trial courts may order "reasonable" discovery of information relevant to the

283. The attorney-client privilege may provide protection against discovery of the subclass of expert investigation involving communication from the defendant to the expert. See infra Part IV, Section $C$. Such protection would not extend to expert investigation not requiring defendant's participation, except in the extraordinary situation in which the attorney learns of the expert report through a confidential communication from the client, as would occur where the defendant has tests conducted and subsequently informs counsel of the results.

284. Gipson v. State, 609 P.2d 1038, 1043 (Alaska 1980); Tafoya v. Baca, 103 N.M. 56, 702 P.2d 1001 (1985).

285. Illinois authorizes broad discovery of defense experts and their reports, subject only to an exception for statements taken from defendant that the defense does not intend to introduce at trial, and subject to "constitutional limitation." ILl. SUP. CT. R. CRIM. P. 413(c). In People ex rel. Bowman v. Woodward, 63 IIl. 2d 382, 349 N.E.2d 57 (1976), the Illinois Supreme Court construed this rule to prohibit discovery of experts and their reports that the defendant did not intend to introducc when the state was ignorant of that information. New Jersey discovery rules once required that the defense permit the state to discover expert test results or reports regardless of the defendant's intention to introduce them. N.J.R. Governing Crim. Prac. 3:13(b)(1). The New Jersey Supreme Court declared the rule unconstitutional as applied to reports that the defense does not intend to introduce at trial. State v. Mingo, 77 N.J. 576, 392 A.2d 590 (1978); see infra notes 336-38 and accompanying text. 
state's case if such discovery would not violate the defendant's constitutional rights. ${ }^{286}$

As far as trial use of the discovered expert or report, the work product doctrine plays only a minor role in most states that permit broad prosecutorial discovery. These states modeled their rules on the 1970 ABA Standards, ${ }^{287}$ which define work product to exclude all nonlegal opinions. $^{288}$ As a result, the narrowly defined work product doctrine

286. These states include Arizona, Illinois, Missouri, Montana, and Utah. See supra note 47. The proposed Michigan rules include a similar provision. See supra note 34. In addition, New Hampshire rules permit the court to order an exchange of all scientific tests and does not explicitly limit disclosure to those tests the defendant intends to introduce. N.H. SuPER. Cr. R. 99. The Missouri courts have interpreted their provisions in various ways. Compare State ex rel. Richardson v. Randall, 660 S.W.2d 699 (Mo. 1983) (en banc) (discovery of identity of handwriting expert whom defense did not intend to call at trial held "unreasonable" under Mo. SuP. Cr. R. 25.06(A), which permits extensive prosecutorial discovery if found "reasonable") with State v. Carter, 641 S.W.2d 54 (Mo. 1982) (en banc) (discovery of nonwitness defense psychiatrist approved under same provision where defendant raised insanity defense), cert. denied, 461 U.S. 932 (1983).

287. See, e.g., ARIz. R. CRIM. P. 15.4(b)(1) comment ("Following the suggestion of $\$ 2.6$ of the ABA, Standards, . . . and the example of [the Illinois and Washington rules] . . this rule adopts a limited work product standard ... protecting documents only to the extent that they constitute legal research or the "theories, opinions and conclusions' of the parties and their agents."). While most states do not reveal so directly the impact of the ABA Standards on their work product provisions, the profound impact of the Standards is clear. First, the three limiting elements of the Standards, see infra note 288, characterize the work product provisions of a number of newly promulgated state rules, see infra note 289. Second, 1969-70 ABA Standards inspired many of these states' entire discovery systems. See, e.g., People v. District Court, 187 Colo. 333, 338, 531 P.2d 626, 629 (1975) (en banc) ("Colorado, in adopting liberal discovery procedures, followed the procedures recommended by the American Bar Association in the ABA Standards.").

288. The 1969-70 ABA Standards define a narrow work product privilege, only for the prosecution, that is limited to "legal research" or "records, correspondence, reports or memoranda" of the "prosecuting attorney or his legal staff . . . to the extent that they contain . . . opinions, theories or conclusions." 1969-70 ABA STANDARDS $\S 2.6$. The commentary clarifies that the concept is narrowly limited to "the thought processes of the prosecuting attorney" and does not include facts. Id. commentary at 90 .

Second, under the Standards, the work product doctrine does not protect experts outside the legal staff of the prosecutor's office. Id. commentary at 91. According to the commentary, this narrow definition facilitates maximum disclosure of information while preserving protection for the most sensitive information of the advocate-his thought processes. Id. commentary at 88-90. The commentary notes that balance of advantage, presumption of innocence, and the constitutional requirement to disclose exculpatory material to the defense supports the maximum disclosure requirement. Id.

Third, the Standards define no work product protection for the defendant. Id. $\$ 3.1-2$. Apparently, the Standards omitted this protection because even arguably discoverable defense materials would not have fallen within the Standards' narrow definition of the work product privilege. As originally proposed, the Standards provided for discovery of only nontestimonial evidence from the defendant, sueh as appearance in a lineup and handwriting exemplars, and of medical and scientific reports. The only discoverable documents were to be medical or scientific reports, which would have been clearly outside the work product doctrine since they would be prepared by experts not on the defendant's staff.

Additional work product issues for the defense arose when the House of Delegates modified the proposed Standards to permit the trial court to order disclosure of the nature of defenses and defense witnesses. Id. $\S 3.3$. When states adopted modified versions of the ABA model, the provision was expanded to require defense disclosure of statements of its witnesses. Because initial developers of 
provides no protection against prosecutorial use of such experts or reports at trial. ${ }^{289}$

In both state and federal law, the work product doctrine stems from public policy considerations. The concern is to protect materials prepared for hitigation purposes from adversary access. ${ }^{290}$ The doctrine is most clearly apphicable at the discovery stage, where the impact of disclosure poses the most direct threat to vigorous case preparation. As such, the doctrine is often formally embodied im the jurisdiction's discovery rules. As a general matter, such rules are by their own terms inapplica-

the Standards foresaw no need for a defense work privilege, they obviously did not consider whether values different from those noted above, which supported a narrow privilege for the prosecution, should shield defense trial preparation efforts from disclosure.

289. Illinois and Missouri define work product to cover both defense counsel and his investigative staff but do not extend it beyond legal theories and conclusions to include scientific opinions. Ill Sup. CT. R. CRiM. P. 412(j)(i); Mo. Super. CT. R. 25.10(A). Alaska provides work product protections only for the prosecution and confines it narrowly to legal opinions, theories, or conclusions. AlASKA CRIM. R. 16(b)(8). New Mexico, which provides for broad, independent prosecutorial discovery patterned on the proposed federal rules, defines work product to include most documents produced by counsel or his agents, but excludes scientific or medical reports. N.M. DisT. CT. R. CRIM. P. 28(b)(1).

Some states fail to define any work product rule for the defense. E.g., Alaska, Arkansas, Colorada, lowa, Maryland, Montana, Nebraska, and Utah. But see People v. District Court, 187 Colo. 333, 342-43, 531 P.2d 626, 631 (1975) (en banc) (state supreme court creates work product privilege for defense similar to statutory privilege provided for prosecution, finding constitutional foundation for its action). Other states limit the persons covered by the rule to the party's legal staff in accordance with the 1969-70 ABA Standards. See, e.g., FLA. R. CRIM P. 3.220(c)(1); ME. R. CrIM. P. 16A(c); MASS R. CRIM. P. 14(a)(5). A third group includes members of the investigative staff within the scope of the rule but shows no inclination to extend the protection beyond legal theories or case analysis to "factual" opinions of experts. See, e.g., ARIz. R. CRIM. P. 15.4(b)(1); Ill. Sup. CT. R. Crim. P. 412(j)(i); MinN. R. Crim. P. 9.02 Subd. 3; Mo. SuP. CT. R. 25.10(A); OR. REV. STAT. \$135.855(1)(a).

By contrast, the federal work product privilege as enacted in 1975 in FED. R. CRIM. P. 16(a)(2), is expansive. It shields all "reports, memoranda, or other internal government documents made by the attorney for the government or other government agents in connection with the investigation or prosecution of the case" from discovery by the defendant, except as specifically provided by other provisions of FED. R. CRIM. P. 16. The privilege is similarly defined in subsection (b)(2) for the defense.

The legislative history of the federal rule shows that adoption of this broad privilege was not motivated by a desire to protect the defense. Congress adopted the Senate's version of the privilege, which had as its primary goal the protection of the names of goverument witnesses and persons interviewed but whom the government did not intend to call. See $8 \mathrm{~J}$. MOORE, MoORE's FEdERAL Practice || 16.01 [4], at 16-32 (2d ed. 1986); Act of July 30, 1975, Pub. L. No. 94-64, 1975 U.S. CodE Cong. \& ADMIN. NEws (89 Stat. 370) 713, 717.

290. See generally United States v. Nobles, 422 U.S. 225, 238 (1975) (work product doctrine has vital role in "assuring the proper functioning of the criminal justice system"); Hickman v. Taylor, 329 U.S. 495 (1947) (disclosure of materials within work product protection violates public policy underlying the orderly prosecution and defense of legal claims); People v. Small, 631 P.2d 148 , 158-59 (Colo. 1981) (en banc) (describing state work product polices as similar to those reflected in Nobles and Hickman), cert. denied, 451 U.S. 1101 (1981); Commonwealth v. Paszko, 391 Mass. 164, 187-88, 461 N.E.2d 222, 236-37 (1984) (work product doctrine is creature of public policy and MASS. R. CRIM. P. 14 preserves its "core" but excludes witness statements and nonlegal reports to further interest in liberal discovery). 
ble once discovery is completed and the trial begun. ${ }^{291}$ Some jurisdictions recognize a work product doctrine beyond this point. ${ }^{292}$ Although derived from the same policy concerns, the privilege available at trial may well be narrower in scope. The demands of the fact finding process support greater disclosure of investigative efforts after pretrial preparation has been completed. At this phase disclosure is less likely to inhibit witness cooperation or thorough preparation. ${ }^{293}$

Where discovery rules embody the work product doctrine, work product is sometimes interpreted to include protections supplemental to exphicit discovery prohibitions in order to avoid subverting their protection. For instance, while Rule 26(b)(4)(B) of the Federal Rules of Civil Procedure explicitly restricts only access to the opinions of experts, some courts also require a showing of "exceptional circumstances" to learn the expert's identity. Otherwise, the courts reason, once the identity is revealed the expert's opinion may be obtained informally or he may be called as a witness at trial. ${ }^{294}$ In addition, where the expert is located inadvertently, use at trial may be prohibited under the theory that otherwise parties will be tempted to let "happenstance" replace formal discovery. ${ }^{295}$

291. See United States v. Nobles, 422 U.S. 225, 234-36 (1975); Morris v. State, 59 Md. App. 659, 669, 477 A.2d 1206, 1211 (1984) (work product doctrine not intended to create evidentiary privilege at trial but only limitation on pretrial discovery); accord People v. Grier, 90 Ill. App. 3d 840, 847, 413 N.E.2d 1316, 1322 (1980); State v. Turner, 97 N.M. 575, 582, 642 P.2d 178, 185 (Ct. App. 1982); State v. Hardy, 293 N.C. 105, 125-26, 235 S.E.2d 828, 840 (1977); see also Feldman, supra note 1, at 506; cf. Note, Proposed 1967 Amendments to the Federal Discovery Rules, 68 ColUM. L. REV. 271, 282 (1968) (special protection for nonwitness experts under FED. R. CIV. P. $26(b)(4)(B)$ based on theory that discovery of all expert efforts would deter thorough preparation, but discovery of only that information favorable enough actually to be used at trial will not deter preparation).

292. Nobles, 422 U.S. at 239; People v. Grier, 90 Ill. App. 3d 840, 847, 413 N.E.2d 1316, 1322 (1980).

293. State v. Hardy, 293 N.C. 105, 125-26, 235 S.E.2d 828, 840 (1977) (identity of state's witnesses already known at trial and disclosure subjects them to no additional risks; major concern at this point is accurate development of facts); accord Grier, 90 Ill. App. 3d at 841, 413 N.E.2d at 1322; $c f$. Morris v. State, 59 Md. App. 659, 669, 477 A.2d 1206, 1211 (1984) (work product doctrine creates no evidentiary privilege but limits pretrial discovery).

294. Ager v. Jane C. Stormont Hosp. \& Training School for Nurses, 622 F.2d 496, 502 (10th Cir. 1980); see also In re Sinking of Barge Ranger I, 92 F.R.D. 486, 488-89 (S.D. Tex. 1981); Guilloz v. Falmouth Hosp. Ass'n, 21 Fed. R. Serv. 2d (Callaghan) 1367, 1371 (D. Mass. 1976); Nemetz v. Aye, 63 F.R.D. 66, 68 (W.D. Pa. 1974); Perry v. W.S. Darley \& Co., 54 F.R.D. 278, 280 (E.D. Wis. 1971); Graham, Discovery of Experts Under Rule 26(b)(4) of the Federal Rules of Civil Procedure: Part Two, An Empirical Study and a Proposal, 1977 U. ILL. L.F. 169, 201-02 (1977). But see In re Folding Carton Antitrust Litigation, 83 F.R.D. 256, 259-60 (N.D. Ill. 1979); Arco Pipeline Co. v. S/S Trade Star, 81 F.R.D. 416, 417 (E.D. Pa. 1978); Baki v. B.F. Diamond Constr. Co., 71 F.R.D. 179, 181-82 (D. Md. 1976); Sea Colony, Inc. v. Continental Ins. Co., 63 F.R.D. 113, 114 (D. Del. 1974); Note, Discovery of the Nonwitness Expert Under Federal Rule of Civil Procedure 26(b)(4)(B), 67 IowA L. REv. 349 (1982)

295. Ager, 622 F.2d at 503. But see Granger v. Wisner, 134 Ariz. 377, 656 P.2d 1238 (1982) (defendant allowed to call plaintiff's expert after inadvertently discovering identity). Where the 
On the other hand, where the formally embodied work product doctrine determines that a class of reports is outside the doctrine's protections, there is no logical extension of the doctrine to madvertent disclosures. Some states exclude reports of expert opmions from the work product doctrine because they contain factual conclusions rather than case analysis. These states, then, have no basis for excluding the reports froin evidence at trial or protecting the doctrine froin indirect subversion by "inadvertent" disclosure. The work product doctrine is, as a policy inatter, simply inapplicable to this entire class of information. As a consequence, if the state's rules permit the prosecution to obtain the expert's identity directly through discovery, admissibility at trial follows. But even if the rules do not exphicitly permit discovery, the work product doctrine creates no bar against use at trial if the prosecution obtains the inforination through other means. ${ }^{296}$

In a situation such as the present hypothetical, the state may learn of the expert examinations even if fornal discovery rules do not require disclosure. Because the defendant is indigent, the prosecution may learn of the examination when his counsel seeks court approval to hire an expert. Any applicable work product protection for the expert opinion should remain even if the state learns of the examination due to the defendant's indigency. The fact that the state is paying for the examination is no justification for it to obtain the results of the tests regardless of

opponent attempts to use informal contacts in order to avoid the restrictions of the rules, the expert's testimony may be excluded from trial as a sanction for violation of discovery rules. Durfinger v. Artiles, 727 F.2d 888, 891 (10th Cir. 1984); Campbell Industries v. M.V. Gemini, 619 F.2d 24, 27 (9th Cir. 1980); see also Note, supra note 294, at 365.66 (party who contacts nonwitness expert without first establishing exceptional circumstances could be subject to contempt).

296. In Morris v. State, 59 Md. App. 659, 477 A.2d 1206 (1984), the Maryland Court of Special Appeals ruled that the state in its case-in-chief properly called a defense expert who analyzed stains on the defendant's shirt. It ruled broadly that the work product privilege provided protection only against pretrial discovery and afforded no evidentiary privilege at trial. The court relied on the discovery rules, which permit pretrial discovery of the reports of experts whom the defendant intends to call at trial. The court also justified the denial of work product protection on a narrower factual basis. The defense expert destroyed the stain in the process of testing it, making impossible further tests by the state expert. Id. at 669-70, $477 \mathrm{~A} .2 \mathrm{~d}$ at 1211-12.

In Illinois, while the courts have not squarely addressed the issue, it is clear that the work product doctrine does not protect experts or their reports from indirect discovery. A number of cases have permitted the prosecution to use defense experts in situations in which the doctrine, if applicable, would have created a barrier to disclosure. See People v. Garza, 92 Ill. App. 3d 723, 734, 415 N.E.2d 1328, 1338 (1981) (defense expert who examined hair sample in state's possession ordered to provide report to state regardless of defense intention to introduce the results at trial); see also People v. Childers, 94 IIl. App. 3d 104, 418 N.E.2d 959 (1981) (psychiatric examination revealed to state through motion for appointment of expert admissible), cert. denied, 455 U.S. 947 (1982); People v. Fowler, 72 Ill. App. 3d 491, 390 N.E.2d 1377 (1979) (handwriting expert retained by defense permitted to testify for state); People v. Speck, 41 Ill. 2d 177, 199-201, 242 N.E.2d 208, 220-21 (1968) (fingerprint expert employed by defense called by government), death sentence vacated, 403 U.S. 946 (1971). 
their outcome. ${ }^{297}$ Similarly, though the state controls the evidence to be tested, that control provides no justification for eliminating any privileges that would otherwise exist. ${ }^{298}$ The state has legitimate interests in assurmg preservation of the evidence and in guaranteeing its admissibility for the state; ${ }^{299}$ but those interests can be protected by conditioning defense access to the evidence-without requiring disclosure of its test results. ${ }^{300}$

Disclosure of the hypothetical test results, which I contend is improper, could be avoided simply by redefining work product in the criminal context to include the identity and the opinions of nonwitness defense experts absent extraordimary prosecutorial need or defense waiver of the privilege. ${ }^{301}$ One of the purposes of the work product doctrine is to protect innovative case preparation. When the expert's opin-

297. In re Mulvaney v. Dubin, 80 A.D.2d 566, 567, 435 N.Y.S.2d 761, 763 (1981) (discovery of defense psychiatric expert-an essential service for effective assistance of counsel-cannot turn on fact that he was paid by the government), rev'd on other grounds, 55 N.Y.2d 668, 431 N.E.2d 292, 446 N.Y.S.2d 931 (1981); cf. Ake v. Oklahoma, 470 U.S. 68, $76-77$ (1985) (indigent defendant must be provided materials essential to building au effective defense and, with respect to those materials, discrimination between indigents and those able to pay is improper); Marshall v. United States, 423 F.2d 1315, 1318 (10th Cir. 1970) (by proceeding under federal statute to obtain expert services, defendant does not waive "disclosure of his case and his concomitant rights against selfincrimination and to due process").

Clearly, actions by the defense, intended to overcome the restrictions of confinement or indigency but which reveal the existence of an expert examination, should not be construed as waiver of auy work product protection otherwise available. See infra note 345. Similarly, information obtained in this manner is not excluded from fifth amendment protections by the Fisher v. United States, 425 U.S. 391 (1976) (holding that the state may compel production of documents only if it has prior knowledge of their existence).

298. It is an entirely different situation where the discovery rule conditions the defense's discovery of prosecution evidence upon reciprocal defense disclosure. See State v. Mingo, 77 N.J. 576, 392 A.2d 590 (1978); People v. Coleates, 86 Misc. 2d 614, 376 N.Y.S.2d 374 (County Ct. 1975) (discovery of photographs in state's possession necessary for defense expert to perform "blood splatter analysis" made contingent upon defendant's providing results to state). Whether the discovery rule is constitutional turns on issues related to the validity of "conditional" discovery. See supra note 141.

299. See People v. Garza, 92 Ill. App. 3d 723, 415 N.E.2d 1328 (1981); Morris v. State, 59 Md. App. 659, 477 A.2d 1206 (1984), discussed supra note 296. In both cases, the state had a legitimate interest in supervising the transfer of its evidence to the defense expert and protecting the integrity of the evidence to assure admissibility at trial. Moreover, since the defendant in Morris refused to stipulate to the chain of custody of the shirt being tested, the trial court correctly ordered that the state could deliver the evidence directly to the defendant's expert and could remain during testing. Since the evidence was destroyed as a result of the testing procedure, the court had a clear justification for denying work product privilege. Obviously, the state could not replicate the examination.

300. For instance, the court could require the defense to stipulate to the authenticity of evidence delivered into its possession. Also, the state could escort the evidence to the expert and supervise its care while in her possession. Nothing in these procedures requires that the defense expert's identity, if learned by the custodian, be disclosed to, or used by, the prosecution.

301. If work product is defined more broadly, then it becomes important how the state learns of the information. It must be determined whether the state's methods constitute a subterfuge or threat to the policies of the doctrine. See supra note 295. Principles of waiver also apply. For a discussion of waiver, see infra notes $344-56$ and accompanying text. 
ion will not be used at trial and other available experts could perform similar tests, the justifications for allowing broad discovery-allowing adequate preparation by the adversary and true litigative unfairness-are absent.

In inany states, the rules' limited defense work product protection apparently derives from a mechanistic extension of the narrow prosecutorial work product doctrine of the $1970 \mathrm{ABA}$ Standards, ${ }^{302}$ as well as from the behef that a narrow construction is critical to prevent discovery from being routinely thwarted by each side. ${ }^{303}$ Careful pohicy analysis suggests that this result is misguided.

The work product doctrine, as apphied to defense preparation, rests on values that support broader protections for the defense than to the prosecution. These include the constitutional right to effective assistance of counsel, the absence of a due process responsibility to provide information helpful to the prosecution, and the practical justification that the state generally enjoys substantially superior investigative resources. ${ }^{304}$

Examination of the protections available under federal civil discovery principles underscores the general inappropriateness of defense preparation discovery when the defendant does not intend to call the witness at trial. For example, Federal Rule of Civil Procedure 26(b)(4)(B) provides that where an expert has been "retained or specially einployed" by the opponent "in anticipation of litigation or preparation for trial," but is not expected to be called as a witness, a party inay discover facts known by that expert or opinions held by him "only . . . upon a showing of exceptional circuinstances under which it is impracticable for the party seeking discovery to obtain facts or opinions on the same subject by other means." Discovery is limited for nonwitness experts because

fear of discovery may deter thorough preparation in cases where an expert's work is not indispensable.... However, when an expert's work

302. See supra note 287.

303. The Massachusetts Supreme Court explicitly linked the expansion of discovery and a limited work product privilege:

Rule 14 of the Massachusetts Rules of Criminal Procedure preserves the "core" of the work product doctrine by "shelter[ing] the mental processes of the attorney," ... but unlike the Federal doctrine, favors liberal discovery by excluding statements of witnesses other than the defendant and nonlegal reports from the definition of work product. The policy of our mles is that the availability of statements of nonparty witnesses gathered by an adversary serves a truth-enhancing function ... that outweighs any resulting inconvenience or potential disincentive to lawyers who obtain and preserve such statements in written form.

Commonwealth v. Paszko, 391 Mass. 164, 187-88, 461 N.E.2d 222, 237 (1984) (quoting United States v. Nobles, 422 U.S. 225, 238 (1975)) (footnote and citations omitted).

304. Cf. In re Sealed Case, 754 F.2d 395, 403 (D.C. Cir. 1985) (Mikva, J., concurring) (attorney-client privilege has broader protection because of sixth amendment concerns in criminal litigation); see also United States v. Nobles, 422 U.S. 225, 238-39 (1975) (work product doctrine is "intensely practical" doctrine that recognizes reality that attorneys must often rely on agents whose product must be protected). 
is indispensable - when the expert will be called as a witness-the danger of surprise and the possible introduction of new issues justify the abandonment of high standards for discovery, especially since the threat of disclosure of the information favorable enough to be used at trial probably will not deter preparation of a case. ${ }^{305}$

The pohicies behind the civil discovery rules further vigorous litigation "by precluding unreasonable access to an opposing party's diligent trial preparation." 306 If these pohicies prohibit access to experts whom the civil hitigant does not intend to call at trial, analogous policies should even more certainly extend the same protection to the nonwitness expert of the criminal defendant. The interests in civil cases gain additional vigor in criminal hitigation from the strength of the defendant's constitutional right to due process, his privilege against self-incrimination, and the guarantee of effective assistance of counsel. ${ }^{307}$ Furthermore, if waiver is appropriately defined, legitimate defense interests can be protected while maintaining discovery for information that may be presented at trial as to which advance notice is critical.

\section{The Effective Assistance of Counsel Guarantee of the Sixth Amendment}

The sixth amendment right to effective assistance of counsel should independently provide protection for defense experts in appropriate situations. Sixth amendment protection should not turn on the availability of work product doctrime or fifth amendment protections. I contend that the sixth amendment prohibits the prosecution from using the investigative efforts of defense experts that are siguificantly damaging to the defense, unless the defense itself uses some aspect of the work to its advantage. In requiring disclosure and permitting use of such efforts, the state significantly interferes with counsel's ability to decide independently how best to defend her chent. This interference violates the sixth amendment.

In United States v. Cronic, ${ }^{308}$ and Strickland v. Washington, ${ }^{309}$ the United States Supreme Court attempted to provide something of an inte-

305. Note, supra note 291, at 282.

306. Durflinger v. Artiles, 727 F.2d 888, 891 (10th Cir. 1984).

307. Ironically, under current criminal discovery practices, the results may be just the opposite. See, e.g., State v. Carter, 641 S.W.2d 54, 64 (Mo. 1982) (en banc) (Seiler, J., dissenting) (discovery of nonwitness defense psychiatrist approved under criminal discovery rule permitting discovery of information relevant and material to state's case would not have been possible under state's civil discovery rules which do not authorize discovery of either identity or opinions of nonwitness experts), cert. denied, 461 U.S. 932 (1983).

308. 466 U.S. 648 (1984) (inexperience of counsel or complexity of case not basis for ineffective assistance where such characteristics did not affect ability of defendant to receive fair trial).

309. 466 U.S. 668 (1984) (ineffective assistance not found where attorney's strategy was reasonable and defendant failed to show that counsel's performance had likely impact on outcome). 
grated systein for analyzing effective assistance of counsel issues. Unfortunately, the Court did not clearly indicate in these cases the mode of analysis it would use regarding discovery of defense experts or how it would resolve the issue raised by such discovery. The Court stated in Washington that the "[g]overnment violates the right to effective assistance when it interferes in certain ways with the ability of counsel to inake mdependent decisions about how to conduct the defense." 310 Such sixth amendment violations include a bar on consultation between attorney and chent durnig an overnight recess, ${ }^{311}$ a bar on defense summation at judge trials, ${ }^{312}$ a bar on direct examination of the defendant, ${ }^{313}$ and the requirement that the defendant testify as the first defense witness if he is to testify at all. ${ }^{314}$ The Court observed that in cases in which the state directly interfered with the defendant's right to counsel, harm to the defendant was so likely that prejudice should be presuined. ${ }^{315}$ The Court also observed that such impairments of counsel were easy to identify and simple to prevent because the government was directly responsible for them. ${ }^{316}$

State rules that require disclosure of damaging defense experts deter vigorous defense mvestigative efforts generally and thereby deny effective assistance of counsel. Such rules appear similar to previously discussed restrictions that courts have held automatically to violate the sixth amendment. Nevertheless, it is far from clear whether rules requiring such disclosure involve per se violations of effective assistance of counsel.

One reason for this lack of clarity is that in those cases in which the Supreine Court has recognized a sixth amendment violation, the state interference with counsel's conduct has been certam. Here, whether the defense will in fact be deterred is to some degree a inatter of conjecture. A second reason is that the Court has yet to give any adequate systematic guidance on what restrictions upon defense conduct are pernissible. In its meffective assistance cases, the Court has only said that once the restriction has been found within an imperniissible class, prejudice will be presumed. ${ }^{317}$ These cases fail to clarify whether requiring the defense to make its investigative efforts available to the state is impernissible or is instead an appropriate inethod of furthernig the state's interest in hav-

310. Id. at 686 .

311. Geders v. United States, 425 U.S. 80, 91 (1976).

312. Herring v. New York, 422 U.S. 853, 865 (1975).

313. Ferguson v. Georgia, 365 U.S. 570, 596 (1961).

314. Brooks v. Tennessee, 406 U.S. 605, 612-13 (1972) (alternative holding).

315. Strickland v. Washington, 466 U.S. 668, 692 (1984); see also United States v. Cronic, 466 U.S. 648, 659 n.25 (1984).

316. Washington, 466 U.S. at 692.

317. Id.; Cronic, 466 U.S. at 659 n.25. 
ing all probative information presented to the finder of fact. ${ }^{318}$

One important feature of the sixth amendment analysis apparent from the cases is that the government's interference with counsel's actions must be purposeful. This feature is clearly present in discovery of unsuccessful investigative efforts. Purposefulness alone, however, does not produce a constitutional violation. In United States v. Morrison, ${ }^{319}$ the Court assuined without deciding that the sixth amendinent was violated when federal investigators disparaged counsel and unsuccessfully attempted to convince the defendant to change lawyers and cooperate with the prosecution. Since the defense alleged no adverse effect upon counsel's effectiveness and showed no prejudice, the Court ultimately held that no reinedy was appropriate..$^{320}$ It also found no violation of right to counsel in Weatherford v. Bursey, ${ }^{321}$ where an informant participated in conversations between a defendant and his attorney. The Court einphasized that the intrusion was not purposeful and that the informant neither told the prosecution what he had heard nor testified about it at trial. $^{322}$

As these two cases demonstrate, reversal of a conviction is required only when the prosecution obtains some arguable advantage as a result of governmental intrusion. ${ }^{323}$ While these cases do not describe the extent of the prejudice necessary for reversal, they suggest a lesser degree of prejudice would lead to reversal when the state caused the incompetence of counsel than when it did not. ${ }^{324}$

In addition to prejudice to the individual defendant, courts are concerned about a potential "chilling" effect upon counsel's efforts in general when the governinent purposefully interferes with counsel's actions. In Weatherford, the government conceded the validity of a similar arguinent: "the Sixth Amendinent's assistance-of-counsel guarantee can be meaningfully impleinented only if a criminal defendant knows that his

318. See Lakeside v. Oregon, 435 U.S. 333, $341-42$ (1978) (sixth amendment right to counsel does not invalidate an otherwise substantively proper but restrictive procedural rule simply because that rule limits counsel's advice, since such advice is appropriate only for substantively valid practices); see also 2 W. LAFAve \& J. ISRAEL, CRIMINAL Procedure, supra note $164, \S 11.8$, at 71 (1984) ("In each of these cases, [Geders, Herring, Brooks, Ferguson] it should be noted, the Court might also have found the particular restriction unconstitutional on the ground that it imposed an undue burden on the exercise of a constitutionally protected right.").

319. 449 U.S. 361 (1981).

320. Id. at $366-67$.

321. 429 U.S. 545 (1977).

322. Id. at 558.

323. 2 W. LAFAve \& J. ISRael, Criminal Procedure, supra note 164, $\S 11.8$, at 75 (1984) (in absence of adverse impact on criminal proceeding, no reason not to allow proceeding to go forward despite constitutional infringement).

324. Strickland v. Washington, 466 U.S. 668, 694 (1984) (where ineffective assistance was not caused by state action, the relevant standard for prejudice is "reasonable probability" that absent counsel's errors result would have been different). 
commumications with his attorney are private and that his lawful preparations for trial are secure against intrusion by the government, his adversary in the criminal proceeding." 325

In other words, the government acknowledged that even if the information obtained through an intrusion into the attorney-chent relationship would not itself have been so prejudicial as to warrant reversal, reversal would be required due to the overall chilling effect such practices would have upon defense efforts. Similarly, even if state use of the results of defense investigative efforts were not inherently prejudicial in a particular case, the potential impact on defense efforts in general might have been so great as to deny effective assistance of counsel. Though counsel was not deterred from undertaking the effort which proved unsuccessful, he may have been deterred from making other appropriate, but perhaps even inore dangerous, inquiries.

This analysis does not mean that a sixth amendment violation would occur in each instance where a discovery rule authorizes the state to receive disclosures of unsuccessful defense investigative efforts. The issue is the permissible scope of such a discovery rule. If discovery is confined, for example, to disclosures of a type that would not cause substantial harm to the defense, then the rule would not logically deter vigorous defense efforts. The threat of disclosure would simply be too insignificant to "chill" the exercise of the constitutional right. ${ }^{326}$ If the rule would permit disclosure of substantially damaging information, however, the fact that the actual disclosure was of relatively minor importance should not be dispositive. Prejudice flows not only froin the direct detrimental impact of the rule on the specific defendant, but also from its deterrence of other possible defense efforts by the specific defendant's attorney and those similarly situated. ${ }^{327}$

325. Weatherford v. Bursey, 429 U.S. 545, $554 \mathrm{n.4}$ (1977) (quoting Brief for United States as Amicus Curiae at 24 n.13 (quoting Brief for Appellee at 71, Hoffa v. United States, 385 U.S. 293 (1966))).

326. See State v. Ortega, 198 N.J. Super. 161, 165, 486 A.2d 904, 906 (1985) (impact of permitting prosecution to use tape recording of lineup proceedings made by defense investigator insignificant given ability of other witnesses present to testify to events recorded).

327. Whether the harmless error doctrine of Chapman v. California, 386 U.S. 18 (1967) should apply to such violations is less clear. The state may argue harmless error by showing not only that disclosure of the defense's unsuccessful effort did not influence the case's outcome, but also that no other, possibly deterred, effort could have made a difference, $C f$. Babcock, Fair Play: Evidence Favorable to an Accused and Effective Assistance of Counsel, 34 STAN. L. REv. 1133, 1169 (1982) (when ineffective assistance was not produced by state interference, prosecution could conceivably demonstrate harmless error by showing steps omitted by counsel would not have aided defense, but government's burden would be very difficult to meet).

On the other hand, a showing of harmless error in the instant case leaves undisturbed the chance that other defense counsel will be inhibited by the prospect of government access to unsuccessful efforts. Resolution of the issue turns on the relative importance placed upon the prejudice in the specific case versus the damaging impact of the practice in general. $C f$. Note, Attorney-Client Communications of Criminal Defendants: Evidentiary and Constitutional Protections, 
In sum, the Court's ineffective assistance cases give no direct guidance for the resolution of the issues posed here. The outcome in any particular case will depend upon the Court's evaluation of the likelihood that the threatened disclosure will substantially deter vigorous defense efforts and the willingness of the Court to focus on systemic effects rather than on the harm in the individual case. Such willingness is not yet apparent. Cronic and Washington reflect a case-speciflc focus and ignore arguments that requiring specific proof of substantial prejudice leaves untouched the major problem of widespread, inadequate representation for indigent defendants. ${ }^{328}$ These cases suggest, then, that a "chilling effect" would not warrant declaring a discovery rule unconstitutional. Nor would such a general effect warrant reversing a conviction unless the particular defendant suffered substantial, specific prejudice from the apphication of a rule that the Court also finds substantively unfair.

I contend that a discovery rule's constitutionality under the sixth amendment should be evaluated by its impact on provision of defense services generally. ${ }^{329}$ A rule allowing any incriminating information developed during defense preparation to be used against the defendant would impair both a vigorous defense effort, which is central to the adversary system, and the defendant-counsel relationship. ${ }^{330}$ Moreover, the inexperience and poor quality of defense counsel typically involved in

62 WASH. U.L.Q. $739,745-46$ (1985) (costs of attorney-client privilege can only be justified at systemic level, not in a particular case; requiring case-specific prejudice inevitably dilutes the privilege).

328. See Babcock, supra note 327, at 1163-74 (once serious incompetence is shown, no prejudice should be required because operation of entire adversary system, including ability to detect errors, depends upon relative equality among opponents).

329. This is not the standard typically applied to inadequate representation by counsel absent specific state interference with his efforts. See Strickland v. Washington, 466 U.S. 668, 688, 694 (1984) (two-part test: first, counsel's representation must fall below an objective, reasonable standard and second, the defendant must show a reasonable probability that but for counsel's errors, the result would have been different); see also Hill v. Lockhart, 106 S. Ct. 366, 371 (1985) (specific prejudice must be shown that would have altered outcome of case where counsel gave erroneous information that induced defendant to plead guilty).

Indeed, given the Court's restrictive treatment of ineffective assistance of counsel claims, a reasonable observer would predict that, regardless of the strength of the arguments to the contrary, the Court will require specific prejudice and will decline to invalidate rules for their "chilling impact" on vigorous investigation and case development. See Weiner, Federal Grand Jury Subpoenas to Attorneys: A Proposal for Reform, 23 AM. CRIM. L. REV. 95, 124 (1985) (unlikely that Supremc Court would rely on chilling impact of subpoenaing lawyers upon candid lawyer-client exchanges rather than requiring specific showing of prejudiee).

330. The consequences would be similar to those that would result from eliminating aspects of the attorney-client privilege. See Fisher v. United States, 425 U.S. 391, 403 (1976) ("II]r the client knows that damaging information could more readily be obtained from the attorney following disclosure than from himself in the absense of disclosure, the client would be reluctant to confide in his lawyer and it would be difficult to obtain fully informed legal advice.").

For many reasons, client mistrust of counsel is especially great in criminal cases, and particularly so for publicly appointed counsel. Mounts, Public Defender Programs, Professional 
criminal cases, the general lack of adequate resources to support the defense, and the structural impediments to effective representations have frequently been noted. ${ }^{331}$ Any procedure that further impedes such efforts must be viewed with alarm.

For example, the defense attorney often faces difficulty in obtaining accurate information regarding the case. She often begins with a murky picture of what occurred and few ideas about how the case should be defended or on what terms it should be bargained. She must be permitted to explore the facts without fearing potential creation of evidence for the state. If each failure adds to the considerable advantage typically enjoyed by the prosecution, prudent counsel may investigate only when she beheves the likelihood of producing favorable resnlts is very substantial. As a consequence, she inay lose important opportumities. ${ }^{332}$

Also, many, if not most, relations between attorney and criminal defendant begin with distrust. ${ }^{333}$ The right of the prosecution to obtam unfavorable resnlts and witness statements from the defense would inevitably exacerbate these tensions. Few defendants wonld not retain a law-

Responsibility, and Competent Representation, 1982 WIS. L. REV. 473, 474 \& n.1. These tenuous relationships cannot easily survive the impact of "betrayal" of unsuccessful investigative efforts.

Even though the proposed treatment of ineffective assistance focuses on the impact of disclosure on the system as a whole, its impact on the state's legitimate interests in discovery should be relatively minor. As discussed below, see infra text accoinpanying notes 343-56, a properly limited waiver concept will protect those interests when the need for disclosure is most pressing.

331. See Bazelon, The Realities of Gideon and Argersinger, 64 GEO. L.J. 811, 812-16 (1976) (indigents "represented all too often by 'walking violations of the Sixth Amendment" "); see also United States v. Bagley, 105 S. Ct. 3375, 3390 (1985) (Marshall, J., dissenting) ("Many, perhaps most, criminal defendants in the United States are represented by appointed counsel, who often are paid mininal wages and operate on shoestring budgets."); Schwarzer, Dealing with Incompetent Counsel-The Trial Judge's Role, 93 HARv. L. REv. 633, 634 \& nn.7-8 (1980) ("staggering case loads and limited resources" lead to a less-than-adequate performance by approximately one-tenth of criminal lawyers); Comment, Representation for Indigent Criminal Defendants in American Courts, 7 CR1M. JusT. J. 417, 430-31 (1984) (author notes problems concerning inexperienced counsel, continued acquisition of cases regardless of professional reputation, and inadequate and uneven funding for defense attomeys and experts); Comment, Liberal Review of Defense Counsel's Performance: The Normal Competency Test, 1976 U. ILL. L.F. 407, 408-11 ("All three branches of the criminal justice system as well as the system itself presently contribute to the lack of effective defense counsel.").

332. Many of these same arguments were advanced against enactment of FED. R. CRIM. P. 26.1 and against similar rules in the states that require defense counsel to provide written statements of defense witnesses to the prosecution after those witnesses have testified. See generally Pulaski, supra note 44 (rule 26.1 is probably unconstitutional and certainly imposes unnecessary burdens on the efforts of defense attorneys expeditiously to prepare cases for trial). I need not reargue the issue. The balance between the detrimental impact upon the defense and the legitimate interest of the state is substantially different in the case of discovery of defense experts, thus rendering these discovery rules unconstitutional.

333. See Wice \& Suwak, Current Realities of Public Defender Programs: A National Survey and Analysis, 10 CR1M. L. BuLL. 161, 171 (1974) (initial meetings between lawyer and criminal defendant "occur $[$ in an atmosphere of suspicion and bitterness" with clients fearing that counsel is tool of prosecution); Mounts, supra note 330 , at $474 \& \mathrm{n} .1$ (clients generally suspicious and hostile toward public defenders). 
yer because of the danger that investigative efforts would be revealed to the prosecution. ${ }^{334}$ The lawyer's notice to the defendant, however, that her latest investigative effort will be used to establish the client's guilt would devastate the typical tenuous relationship. ${ }^{335}$

Cases decided by the Supreme Court of New Jersey provide useful illustrations of the analysis I advance here. In State v. Mingo, ${ }^{336}$ defense counsel moved under the state's discovery statute for access to a note written by the assailant in order to have an expert perform a handwriting analysis. Under the state's conditional discovery rule, counsel's request for the note triggered an obligation to provide extensive discovery to the state. $^{337}$ Furthermore, the trial court specifically conditioned access upon counsel's agreement to disclose the handwriting expert's report to the state regardless of its outcome. The examination showed that the defendant wrote the note. When the expert's report was provided, as ordered, to the state, the prosecution subpoenaed the expert and called him in its case-in-chief. The court observed that:

To safeguard the defense attorney's ability to provide the effective assistance guaranteed by these constitutional provisions [right to counsel under the United States and New Jersey Constitutions], it is essential that [counsel] be permitted full investigative latitude in developing a meritorious defense on his chent's behalf. This latitude will be circuniscribed if defense counsel must risk a potentially crippling revelation to the State of

334. For discussion of the ways in which discovery of defense experts and their results varies depending upon whether the defendant is represented by counsel or is proceeding pro se see supra text accompanying notes 279-83.

335. Cf. Fisher v. United States, 425 U.S. 391, 403 (1976). The Court recognized that clients would be reluctant to provide information to counsel without an attorney-client privilege since such information could more readily be obtained from counsel than defendant. The result would be restricted communication and less informed legal advice. Because the privilege withholds relevant information from the factinder, however, it is limited to disclosures that "might not have been made absent the privilege." Id.

The attorney-client privilege theoretically protects only communications. Nevertheless, it also shields the contents of the privileged communication. Clearly the facts contained in the communication are not themselves protected as a direct consequence of being communicated to an attorney. The protection afforded to the communication nuay, however, deny the opponent access to those facts if she finds no alternative source of the information.

In Upjohn Co. v. United States, 449 U.S. 383 (1981), the Court recognized that the attorneyclient protection of communication imposes little real cost on the adversary. Though the adversary loses the convenience of using the communication, she is in no worse position than if the communication had never taken place. Id. at 395-96. Indeed, under the general theory of the privilege that its purpose and effect is to encourage frank communications between lawyer and client, id. at 389 , there is good reason to believe that no communication would have been made absent the privilege's protections.

A sinilar argument applies here. If discovery is freely allowed, expert examinations are not likely to be completed in niany situations. Thus, either with or without a discovery right, the state would not receivc the expert opinion. Without the protection, however, the defense effort will be the poorer, and the adversarial goal of a vigorous development of both sides of the issue will suffer.

336. 77 N.J. 576, 392 A.2d 590 (1978).

337. N.J. R. Governing Crim. Prac. 3:13-3(b). 
information discovered in the course of investigation which he chooses not to use at trial. ...

..."The attorney inust be free to inake an informed judgment with respect to the best course for the defense without the inhibition of creating a potential government witness." 338

From this analysis, the court found that the state's conditional discovery rule as apphied in the case violated the defendant's constitutional right to effective assistance of counsel. ${ }^{339}$

In State v. Williams, ${ }^{340}$ defense counsel and his mvestigator asked the victim to identify her attacker from a group of photographs that mcluded a picture of the defendant. She selected the defendant's photograph. The state moved for discovery of the pictures shown to the victim and memoranda of the mterview. Defense counsel objected, asserting, not unexpectedly, that he did not intend to use the unfavorable material at trial. Under the discovery rules, ${ }^{341}$ the trial court ordered discovery of those items, and the state used them in its case-in-chief. ${ }^{342}$

The state supreme court held that the defendant's right to effective assistance of counsel had been violated under the basic theory of Mingo, as well as under an exphicit work product rationale.

The investigative course selected by an attorney in order to prepare a proper defense for his client frequently entails a high order of discretion. This often calls for more than simple fact gathering. Evidential inaterials obtained in the exercise of this professional responsibility are so interwoven with the professional judgments relating to a client's case, strategy and tactics that they may be said to share the characteristics of an attorney's "work product." Blanket discovery of the fruits of this kind of legal creativity and preparation may inpact directly upon the freedom and initiative which a lawyer must have in order to fully represent his client. Curtailment or inhibition of this attorney function by discovery, not otherwise justified to avoid trial surprise, would permit the State to

338. Mingo, 77 N.J. at 581-82, 392 A.2d at 592-93 (quoting United States v. Alvarez, 519 F.2d 1036, 1047 (3d Cir. 1975)).

339. Mingo, 77 N.J. at 587, 392 A.2d at 595. Nevertheless, the court found the error constitutionally harmless on the ground that it had not prejudiced the defendant's case. Id. at 58889,392 A.2d at 596. In declining to reverse the defendant's conviction, the court had no need to fear a chilling impact of the discovery practice on other defendants because it declared that "henceforth [such discovery] by the State will be impermissible by reason of our ruling herein." Id; see also supra note 324.

340. 80 N.J. 472 , 404 A.2d 34 (1979).

341. N.J. R. Governing CRIM. Prac. 3:13-3(b)(4) requires that the defendant permit discovery of "written statements, if any, including any memoranda reporting or summarizing the oral statements, made by any witnesses whom the State may call as a witness at trial" if the defendant seeks any discovery under the statute. In Williams, the defense triggered the reciprocal requirement by obtaining discovery from the prosecution of the names and addresses of its witnesses. Williams, 80 N.J. at 484,404 A.2d at 40 (Schreiber, J., dissenting).

342. To avoid testifying, defense counsel stipulated that the victim selected the defendant's photograph during his interview with her. Williams, 80 N.J. at 476, 404 A.2d at 36. 
undermine the effectiveness of an attorney in serving his client. ${ }^{343}$

Following this analysis for the hypothetical rape case set out earlier, a discovery rule that would require the defense to divulge unsuccessful test results should be declared unconstitutional. The rule would stifle legitimate investigation and lacks justification on the basis of substantial state interests.

\section{Waiver as a Conditional Concept}

Because state courts have not treated the work product doctrine and the sixth amendinent as serious protections against improper discovery, they have not analyzed the appropriate scope for the waiver doctrine regarding these protections. If applied rigidly, waiver concepts may force the defendant to choose between forfeiting these protections or complying with discovery rules requiring disclosure of anticipated defenses. Waiver should instead be imterpreted to promote the protections provided under the sixth amendinent and the work product doctrine while reconciling them with legitimate state concern over unfair surprise.

Whether apphed to the work product doctrine or to the constitutional right of effective assistance of counsel, waiver should be found only after careful analysis. ${ }^{344}$ The defense has an important and legitimate

343. Id. at $479,404 \mathrm{~A} .2 \mathrm{~d}$ at 38 (citation omitted).

In subsequent cases, the New Jersey courts have explored the limits of this doctrine. In State v. Doe, 161 N.J. Super. 187, 391 A.2d 542 (1978), the court reversed on sixth amendment grounds a trial court's order prohibiting a defense polygraph expert from examining a jailed defendant. The visit was barred because defense counsel refused to comply with a standing judicial order that the prosecutor be notified of any visits of experts to confined defendants. The court found it "entirely conceivable that if the prosecutor had to be notified every time a confined defendant had need for a visit from an expert, whether or not the expert's report was to be used at trial, a chilling effect on the conduct of effective and complete defense investigations could occur." Id. at 189, 391 A.2d at 543.

In State v. Ortega, 198 N.J. Super. 161, 486 A.2d 904 (1985), the court found no constitutional violation where defense counsel was ordered to give the prosecution a tape recording of a lineup. The tape had been made by a defense investigator, but the defense did not intend to use it at trial. Apparently, the court found no violation of effective assistance of counsel because the impact upon defense efforts would be de minimis. Had discovery been denied, prosecution witnesses present at the lineup could have testified concerning what had occurred.

344. In some jurisdictions where the work product privilege covers defense expert reports, courts have held that voluntary disclosures made during efforts to plea bargain waive the privilege. State v. Jackson, 97 N.M. 467, 469, 641 P.2d 498, 500 (1982) (psychiatric examination of victim by defense expert introduced by state after defendant instructed expert to reveal findings to prosecution and then suggested plea agreement; voluntary disclosure held to waive any privileges available, although opinion may be read to indicate that work product doctrine covered only discovery stage and was inapplicable at trial); State v. Malzac, 309 Minn. 300, 308-09, 244 N.W.2d 258, 263 (1976) (deposition of defense ballistic expert admitted at trial over work product claim because defense disclosed report during "process of willing compromise and negotiation" that "waived any workproduct-privilege claim that [defense] might have asserted").

Finding waiver in the plea-bargaining situation may be tolerable since it leaves the defense the choice, although a difficult one, of whether to waive the privilege in order to gain a litigative benefit. 
interest both during discovery and at trial in protecting the fruits of its investigative efforts. Unless it intends to, and does, use such information at trial, the principal justification for prosecutorial discovery-avoidance of unfairness through surprise-has no apphication. Thus, waiver of the right to protect such information at trial should occur only when the defense actually introduces inforination developed by the expert.

In this area, waiver should be defined as a two-stage, or conditional, concept. $^{345}$ By indicating its intention to use the expert, the defense

But waiver should be found only when the defense seeks to make affirmative use of the protected materials. See Note, Waiver of the Work Product Immunity, 1981 U. ILL. L. REv. 953, 968-69 (1981) (work product should be held to be waived only where information voluntarily revealed to adversary). The wisdon of finding waiver in the voluntary plea-bargaining situation is questionable, lowever. Imposing possible costs contravenes the policy favoring negotiated pleas, see, e.g., FED. R. EVID. 410, FED. R. CRIM. P. 11(e), and inay conflict with the broader purpose of the work product privilege to facilitate efficient operation of the adversary system, which depends leavily upon such bargaining. See Feldman, supra note 1, at 539-40 (plea negotiations are to be encouraged and sloould not be inhibited by fear that disclosures will waive privilege).

A more troublesome concept of waiver permits the government to call a defense expert where the defendant's testimony is inconsistent witl the resnlts of the examination. In State v. Harrison, 90 N.M. 439, 564 P.2d 1321 (1977), superseded by rule change, see Tafoya v. Baca, 103 N.M. 56, 702 P.2d 1001 (1985), an indigent defendant took a polygrapl examination at state expense. Under state law the test was admissible. See, e.g., State v. Bell, 90 N.M. 134, 138, 560 P.2d 925, 929 (1977); State v. Dorsey, 88 N.M. 184, 184-85, 539 P.2d 204, 204-05 (1975); N.M. R. Evid. 707 (effective 1983). Thereafter, defense counsel informed the state that he would not disclose the test results. Altliough the rules clearly did not authorize discovery, see N.M. DIST. CT. R. CRIM. P. 28(a)(2), since the defense did not intend to introduce the report or call the polygraph exarniner, the state inoved for production.

The trial court ruled that the state could not call the polygrapls examiner to testify in its case-inclief. After the defendant testified, however, the court permitted the examiner to be called and questioned about both his conclusion that the defendant's test responses were untrutliful and the statements made by defendant during the examination. The state supreme court affirmed. It rejected work product and attorney-client objections as well as claims of due process and equal protection protections. The court simplistically rested its conclusion upon a "waiver" rationale supported solely by Harris v. New York, 401 U.S. 222 (1971); see also U.S. v. Milano, 443 F.2d 1022, 1027-28 (10th Cir.) (testimony of defense handwriting expert admitted under similar rationale to impeacl defendant's claim that handwriting on bank robbery note was not his), cert. denied, 404 U.S. 943 (1971).

Harrison and Milano give an entirely untenable meaning to waiver of work product doctrine. Under their rationale, waiver occurs if the defendant's testimony contradicts the results of a test even if the defense makes no affirmative use of that test. Such a broad view of waiver could logically apply to any expert opinion inconsistent with evidence offered by the defense.

345. Protection under both the attorney-client privilege and the work product doctrine is generally considered inconsistent witl any purposeful disclosure to the adversary. Waiver of attorney-client privilege occurs when the client or the attorney, acting under the client's authorization, voluntarily reveals the confidential communication to anyone outside the confidential relationship. In re Sealed Case, 676 F.2d 793, 809 (D.C. Cir. 1982) (any voluntary disclosure to third party constitutes waiver); MCCORMICK ON EvIDENCE $\S 93$ (E. Cleary 3d ed. 1984). Waiver of work product privilege is more narrowly construed; it oceurs when information is voluntarily communicated to the adversary. $8 \mathrm{C}$. Wright \& A. Miller, Federal Practice and Procedure § 2024, at 210 (1970); Cohn, The Work-Product Doctrine: Protection, Not Privilege, 71 GEO. L.J. 917, 936-38 (1983); Feldman, supra note 1, at 538-39.

Nevertheless, because new contexts with coinpeting interests require a more flexible concept, a conditional waiver concept has gained recognition with some courts and commentators. See State v. 
waives confidentiality for discovery purposes. Disclosure should not waive the defendant's right to control testimonial use of the expert. If the defense never calls the expert, disclosure of his report should not entitle the state to call him. The prosecution has suffered no affirmative harm, and absent such harm, the defense should be able to preserve its exclusive right to call the expert. By providing discovery of the expert, the defense enables the state to prepare its response. Discovery would not, however, operate to waive the defense's right to prevent admission of the expert's testimony. ${ }^{346}$

\section{B. Discovery of Statements Made by Witnesses to the Defense}

The foregoing discussion has focused on discovery of defense expert witnesses. In this section, I discuss discovery rules that require the defense to provide statements of any witnesses from whom it has taken written statements. In some instances the rules require the defense to create statements of its witnesses specifically for discovery.

The 1970 ABA Standards, even in final form, required that only the prosecution provide witness statements. As noted above, fifteen states wrote rules that inandate that the defense also provide witness statements. ${ }^{347}$ Two of those went further, and their rules require the defense to generate statements even when counsel would not choose independently to do so. ${ }^{348}$ In addition, rules in three states require the defense to provide the prosecution with witness statements, not only of defense witnesses, but also of witnesses. whom the state will call, regardless of whether the defense intends to use the statements to impeach the government's witnesses at trial. ${ }^{349}$

Those states that require the broad production of witness statements

Jones, 99 Wash. 2d 735, 750, 664 P.2d 1216, 1224 (1983) (disclosure to prosecution of defense psychiatric examination that contained communications within attorney-client privilege does not waive privilege; waiver occurs only where evidence is used at trial to prevent defense presenting " "one-sided account of the matters in dispute," " using "privilege as a sword rather than a shield") (quoting State v. Pam, 98 Wash. 2d 748, 764 n.7, 659 P.2d 454, 462 n.1 (1983) (quoting Brown v. United States, 356 U.S. 148, 155 (1958))), Saltzburg, Privileges and Professionals: Lawyers and Psychiatrists, 66 VA. L. Rev. 597, 647 (1980); see also State v. Mines, 35 Wash. App. 932, 937-39, 671 P.2d 273, 277 (1983); cf. United States v. Alvarez, 519 F.2d 1036, 1046 (3d Cir. 1975) (attorneyclient privilege not waived by compliance with discovery rule that compelled advance disclosure of one expert's opinion on defendant's sanity where defense chose to introduee contrary reports by another expert at trial).

346. In State v. Mingo, 77 N.J. 576, 587, 392 A.2d 590, 595 (1978), the Supreme Court of New Jersey defined precisely the type of two-stage waiver proposed here.

347. See supra notes 40-41.

348. Rhode Island and Washington, see supra note 43.

Such rules may run afoul of the sixth amendment right to effective assistance of counsel under the analysis set out supra in text accompanying notes 308-342.

349. Minnesota, New Jersey, Wisconsin, see supra note 44. The New Jersey Supreme Court, however, declared the rule unconstitutional when applied in this fashion. State v. Williams, 80 N.J. 472, 404 A.2d 34 (1979). See supra notes 340-43 and accompanying text. 
define the work product doctrine to exclude entirely the factual statements of witnesses from its protections. ${ }^{350}$ When states combine such a restrictive definition with requirements that defense counsel create statements that she would not have otherwise generated, or provide statements taken from the prosecution's witnesses that she did not imtend to use at trial, two results follow. First, defense counsel loses the ability to make tactical judgments concerning how the taking of witness statements may affect her case. She is required to create evidentiary materials that may aid her adversary. Moreover, this rule does not correct any unfair defense advantage but serves merely to enhance the general accuracy of the fact-finding process. Second, the defense counsel loses the ability to control her adversary's access to damaging information by choosing trial tactics and strategy that would avoid rehiance upon witness statements.

While the number of states with practices that pose these threats is not large, their challenge to values critical to the adversarial process is substantial. In United States v. Nobles, ${ }^{351}$ the Supreine Court, relying on policies applicable in both state and federal courts, found that work product principles were even more vital to the proper functioning of the criminal justice system than to civil litigation. ${ }^{352}$ In contrast to a number of the states described above, the Court, under its own policy analysis, suggested that statements taken from witnesses were within the federal work product doctrine. ${ }^{353}$ The Supreme Court did not further delineate the scope of the doctrine because it concluded that defense counsel liad waived the work product privilege by making testimonial use of the witness statement for impeachment purposes. ${ }^{354}$

Surely states may properly judge whether the policy interest in encouraging broader discovery warrants the elimination of work product protection for statements of witnesses the defense calls or impeaches at trial. $^{355}$ As to those witnesses, the waiver doctrine embodied in Nobles and the narrow definition of work product as defined in the ABA standards reach the same result. But, where the defense would not independently produce such witness statements in the absence of the rules, and

350. See, e.g., Commonwealth v. Paszko, 391 Mass. 164, 187-88, 461 N.E.2d 222, 236-37 (1984) (asserting that availability of nonparty witness statements gathered by adversary serves to enhance the truth-seeking function); State v. Hardin, 558 S.W.2d 804, 807 (Mo. Ct. App. 1977) (witness statement taken by defense investigator not within work product because it contained recollections of witness rather than impressions of investigator); see supra notes 288-89 and accompanying text.

351. 422 U.S. 225 (1975).

352. Id. at $238 \&$ n. 12 .

353. Id. at 239.

354. Id. at $239 \&$ n. 14.

355. Although the issue is difficult, I do not question the constitutionality of statutes requiring the production of statements by witnesses whom the defense calls or impeaches at trial. Cf. Pulaski, supra note 44, at 16-39 (discussing validity of FED. R. CRIM. P. 26.1 which requires defense counsel to provide statements of defense witnesses at completion of their testimony). 
where statements of prosecution witnesses must be provided regardless of whether they are impeached, the results will differ. When the statements produced either affirmatively harm the defense's case or corroborate the state's case, the difference could have a significant impact beyond matters of public policy, upon which jurisdictions may freely differ. These results would raise substantial issues under the sixth amendment analysis set out above. ${ }^{356}$

\section{Prosecutorial Use of Defendant's Statements Within the Attorney-Client Privilege}

In the past ten years, major developments im the attorney-client privilege have permitted the state to imtroduce at trial statements made by a defendant to agents of his attorney. These statements principally involve commumications between the defendant and defense experts secured to present the insanity defense. Cases both approving and disapproving the prosecutor's right to call such experts often agree that statements by the defendant to an agent of the attorney for the purpose of securing legal services are within the attorney-chent privilege. ${ }^{357}$ Many courts have held, however, that presentation of the insanity defense "waives" the privilege. Also, most courts have ruled that the right to effective assistance of counsel is not violated by prosecutorial use of such experts. ${ }^{358} \mathrm{My}$ concern is not with the specific basis for these decisions;

356. See supra text accompanying notes $308-42$.

357. Cases ultimately upholding the assertion of the privilege freely recognize that the privilege applies to communications with a defense psychiatric expert. Several note that the "complexities of modern existence" require that the lawyer and client communicate through experts. State v. Pratt, 284 Md. 516, 520-21, 398 A.2d 421, 423-24 (1979); People v. Hilliker, 29 Mich. App. 543, 548, 185 N.W.2d 831, 833 (1971). See generally City \& County of San Francisco v. Superior Court, 37 Cal. $2 \mathrm{~d} \mathrm{227,} 231$ P.2d 26 (1951) (recognizing that attorney-client privilege protects communications from physicians to attorneys concerning client's physical or mental condition, particularly since physicians required to interpret conditions for attorney).

Cases finding waiver often assume that an attorney-client privilege applies to this general class of communications. They either find the privilege waived by the defendant's assertion of the insanity defense or conclude it is unavailable as a matter of law based on policies of liberal discovery necessitated by the insanity defense. State v. Craney, 347 N.W.2d 668, 677 (Iowa) (if privilege attaches to such communications, policy of "full disclosure of facts" " relevant to the insanity defense requires disclosure), cert. denied, 469 U.S. 884 (1984); State v. Carter, 641 S.W.2d 54, 57 (Mo. 1982) (en banc) (if privilege attaches, it is waived by assertion of insanity defense), cert. denied, 461 U.S. 932 (1983); State v. Bonds, 98 Wash. 2d 1, 20-22, 653 P.2d 1024, 1035-36 (1982) (privilege extends to psychiatric examinations but is waived by raising insanity defense), cert. denied, 464 U.S. 831 (1983).

358. While the attorney-client privilege is a creation of the common law and legislation, some areas covered by the privilege are also protected by the sixth amendment right to effective assistance of counsel. In Weatherford v. Bursey, 429 U.S. 545 (1977), the government conceded that the right to effective assistance of counsel would be violated "if the government places an informant in the defense camp during a criminal trial and receives from that informant privileged information pertaining to the defense of the criminal charges." Id. at 554 n.4; see also id. 429 U.S. at 563 (Marshall, J., dissenting) ("[I]t has long been recognized that 'the essence of the Sixth Amendment 
confined to their facts, they may be justified. Rather, I am concerned that the courts tend to cast their reasoning in terms of general litigative fairness, terms potentially applicable outside of the insanity defense context. Fully extended, these developinents fundainentally threaten the protections of the attorney-client privilege.

The issue of prosecutorial use of psychiatrists consulted by the defense arises when at least one expert finds that the defendant was "sane" at the time of the crime, and the insanty defense is pursued at trial through the testimony of others. The government in soine fashion learns of the dissenting defense expert ${ }^{359}$ and, over defense objection, calls her either in its case-in-chief ${ }^{360}$ or in rebuttal after presentation of defense testimony supporting the insanity defense. ${ }^{361}$

A number of cases hold tliat the attorney-client privilege forbids government use of these experts unless the defendant waives the privilege by calling the expert in question. ${ }^{362}$ Recent case law, however, tends to find the privilege waived or otherwise unavailable for psychiatric testiinony. These courts conclude that the right to effective assistance of counsel imposes no constitutional restriction upon disclosures concerning psychiatrists' communication with the defendant. ${ }^{363}$

right is ... privacy of communication with counsel.' ") (quoting United States v. Rosner, 485 F.2d 1213, 1224 (2d Cir. 1973), cert. denied, 417 U.S. 950 (1974)).

359. The opinions typically fail to make clear how the state obtains this information. Presumably, in many cases it is a consequence of defense efforts to obtain funds for the examination of the indigent defendant. See, e.g., State v. Moore, 45 Or. App. 837, 609 P.2d 866 (1980) (defendant sought order for appointment of defense psychiatrist). In some states, discovery rules permit state access to defense-generated psychiatric reports regardless of whether the defense intends to call the expert who prepared the report as a witness at trial. State v. Dodis, 314 N.W.2d 233, 240 (Minn. 1982) (MINN. R. CRIM. P. 20.03 permits prosecutorial use of all medical records that "bear on the issue of mental illness"); State v. Carter, 641 S.W.2d 54, 58-59 (Mo. 1982) (en banc) (Mo. R. CRIM. P. 25.06 permits court to order disclosure on reasonable request of state if requested information is material to its case), cert. denied, 461 U.S. 932 (1983).

360. See, e.g., State v. Craney, 347 N.W.2d 668, 671 (lowa 1984) (defendant had given notice of defenses of insanity and diminished responsibility but had introduced no evidence on defenses prior to use of his expert in state's case-in-chief), cert. denied, 469 U.S. 884 (1984).

361. See, e.g., State v. Bonds, 98 Wash. 2d 1, 19-22, 653 P.2d 1024, 1034-36 (1982) (defense expert used at hearing to determine accused's adult status allowed to testify in rebuttal to insanity defense at trial), cert. denied, 464 U.S. 831 (1983); State v. Carter, 641 S.W.2d 54, 56 (Mo. 1982) (state allowed to call in rebuttal an expert defense chose not to use), cert. denied, 461 U.S. 932 (1983).

362. See, e.g., United States v. Alvarez, 519 F.2d 1036, 1046 (3d Cir. 1975); Houston v. State, 602 P.2d 784, 792 (Alaska 1979) (waiver found where expert who testified for defense relied in part on report of nonwitness expert); State v. Toste, 178 Conn. 626, 424 A.2d 293 (1979); Ursury v. State, 428 So. 2d 713, 714 (Fla. Dist. Ct. App. 1983); Pouncy v. State, 353 So. 2d 640, 642 (Fla. Dist. Ct. App. 1977); State v. Pratt, 284 Md. 516, 398 A.2d 421 (1979) (also relying on sixth amendment); People v. Hilliker, 29 Mich. App. 543, 185 N.W.2d 831 (1971); State v. Moore, 45 Or. App. 837, 609 P.2d 866, 869 (1980).

363. At least seven states find that neither the attorney-client privilege nor effective assistance of counsel prohibits disclosure of the testimony of these experts. The highest courts in Iowa, Minnesota, Missouri, and Washington have written opinions on these issues since 1982. Three states 
Some courts have resisted this trend. Courts that have found disclosure improper have held that simply raising the insanity defense or calling other experts is insufficient to waive the privilege. Under this approach, the expert herself must be called to the stand $d^{364}$ or her report otherwise affirmatively used by the defense before waiver will be found. ${ }^{365}$ The Third Circuit, in United States v. Alvarez, ${ }^{366}$ agreed that raising the insanity defense did not waive the attorney-client privilege. The court went even further, ruling that such a broad construction of waiver principles would violate the sixth amendinent. It concluded that if the government were able to call an unfavorable defense psychiatrist, that prospect would have the "inevitable effect of depriving defendants of effective assistance of counsel" because counsel would be inhibited from consulting several experts out of fear that she might "creat[e] a potential

applied explicit waiver concepts to the issue of attorney-client privilege: WASHINGTON-State v. Bonds, 98 Wash. 2d 1, 22, 653 P.2d 1024, 1036 (1982); OHIO-State v. Noggle, No. 3-79-2, slip. op. at 48-50 (Ohio App. Oct. 19, 1978 ) (cited in Noggle v. Marshall, 706 F.2d 1408, 14 I2 (6th Cir.), cert. denied, 464 U.S. 1010 (1983)); NEW YORK-People v. Edney, 39 N.Y.2d 620, 350 N.E.2d 400,385 N.Y.S.2d 23 (1976). Courts in four other states held that there is no privilege applicable to psychiatric opinions and the statements of a defendant upon which they are based in the context of the insanity defense: IOWA-State v. Craney, 347 N.W.2d 668, 676-77 (1984); MINNESOTAState v. Dodis, 314 N.W.2d 233, 240-41 (1982); MISSOURI-State v. Carter, 641 S.W.2d 54, 58-59 (1982); TEXAS — Granviel v. State, 552 S.W.2d 107, 117 (Tex. Ct. App. 1976), cert. denied, 431 U.S. 933 (1977). In each of these states, other than Texas, the courts looked to the liberal disclosure policies of their discovery rules or waiver principles for guidancc in determining the scope of the attorney-client privilege. All seven states found that disclosure did not violate the constitutional right to effective assistance of counsel.

Of similar interest are state discovery mles that limit the privilege in the context of the insanity defense. See supra note 359. Following this trend, recent legislative changes in Michigan permit automatic discovery of defense psychiatric reports where the defendant intends to raise the insanity defense. People v. Sorna, 88 Mich. App. 351, 357-58, 276 N.W.2d 892, 894-95 (1979). The legislation marked a shift in the privilege defined in People v. Hilliker, 29 Mich. App. 543, 185 N.W.2d 831 (1977), where the court found that use of the defense expert by the prosecutor violated the attorney-client privilege. While Hilliker was not explicitly overruled by legislative action, the discussion in Sorna substantially narrowed the privilege it described. Id.

In addition, four federal circuits have addressed the issue. In United States v. Alvarez, 519 F.2d 1036 (3d Cir. 1975), the Third Circuit held that the government violated both the attorney-client privilege and the sixth amendment right to cffective assistance of counsel by calling the defense psychiatrist as a witness at trial. See also United States v. Layton, 90 F.R.D. 520, 524-25 (N.D. Cal. 1981) (attorney-client privilege covering statements by defendant to psychiatrist not waived by raising insanity defense). The Second, Fifth, and Sixth Circuits have subsequently reached a contrary result. See Noggle v. Marshall, 706 F.2d 1408, 1415 (6th Cir. 1983), cert. denied, 464 U.S. 1010 (1983); Granviel v. Estelle, 655 F.2d 673 (5th Cir. 1981), cert. denied, 455 U.S. 1003, 1007 (1982), United States ex rel. Edney v. Smith, 425 F. Supp. 1038, 1046 (E.D.N.Y. 1976), aff'd mem., 556 F.2d 556 (2d Cir.), cert. denied, 431 U.S. 958 (1977).

364. Alvarez, 519 F.2d at 1046 (3d Cir. 1975) ("If the expert is later used as a witness on behalf of the defendant, obviously the cloak of privilege ends."); Pouncy v. State, 353 So. 2d 640, 642 (Fla. Dist. Ct. App. 1977).

365. Houston, 602 P.2d at 790-92 (Alaska 1979) (privilege waived for nonwitness expert where expert who testified for defense relied upon other expert's report in his testimony).

366. 519 F.2d 1036 (3d Cir. 1975). 
government witness."367

The most frequently cited response to Alvarez comes from Judge Weinstem's opinion in United States ex rel. Edney v. Smith ${ }^{368}$ Judge Weinstein recognized that basing waiver on simply raising the insanity defense would go beyond traditional analysis. Nonetheless, he was willing to allow waiver under these circumstances based "on considerations of fairness and the salutary concept that the trier of fact should have adequate access to as inuch of the available psychiatric testimony as possible where the defendant's inental state is in issue." ${ }^{369} \mathrm{He}$ then examined whether a flexible approach to waiver was constitutionally prohibited under the sixth ainendment. He concluded that absent a "more adequate and less speculative demonstration of the prejudice" to defense efforts resulting from this practice, use of the expert did not violate the defendant's constitutional right to effective assistance of counsel. $\mathrm{He}$ was unwilling to terminate further state experimentation with the scope of the privilege absent a more substantial showing that adequate representation would actually be inhibited. ${ }^{370}$

Judge Weinstein's opinion strongly influenced the recent trend allowing discovery and use of defense psychiatric evidence. Professor Saltzburg, too, has provided justification for permitting prosecutorial access to such evidence. ${ }^{371}$ Professor Saltzburg argues that the defense's psychiatric evidence is likely to be substantially superior to any evidence that the government could reasonably obtain on its own. First, the defense expert frequently will examine the defendant closer in time to the incident than any government expert, an important factor in the value of the examination. Second, Professor Saltzburg contends, the defendant is

367. 519 F.2d at 1046-47; see also State v. Pratt, 284 Md. 516, 524, 398 A.2d 421, 425 (1979) ("An additional consequence of the State's suggested waiver rule . . . is that the defense, in essence, would be required to assist the prosecution in discharging its burden of proof.").

368. 425 F. Supp. 1038 (E.D.N.Y. 1976), aff'd mem., 556 F.2d 556 (2d Cir.), cert. denied, 431 U.S. 958 (1977).

369. Id. at 1049.

Judge Scalia's statement in United States v. Byers, 740 F.2d 1104, 1113 (D.C. Cir. 1984) (en banc), concerning waiver of the fifth amendment upon introducing expert testimony is apt here.

It seems to us at best a fiction to say that when the defendant introduces his expert's testimony he "waives" his Fifth Amendment rights. What occurs is surely no waiver in the ordinary sense of a known and voluntary relinquishment, but rather merely the product of the court's decree that the act entails the consequence-a decree that remains to be justified.

"Waiver" is often the term used when a court has decided it just to deny the privilege as a consequence of the defendant's choice to introduce evidence on insanity. But as the Byers court observes, the defendant is definitely not voluntarily relinquishing a known right. Indeed, he frequently vigorously objects to the government's use of his witness. See Noggle v. Marshall, 706 F.2d 1408, 1422-23 (6th Cir. 1983) (Edwards, J., dissenting) (defendant did not specifically waive objection to calling his expert but rather objected vigorously), cert. denied, 464 U.S. 1010 (1983).

370. 425 F. Supp. at 1054-55.

371. Saltzburg, supra note 345 , at 597 . 
likely to be more cooperative with a defense expert. Third, the defendant may learn how to distort his responses based on the experience of his first examination and thereby be able to mislead later government experts. ${ }^{372}$

There are substantial reasons to doubt that Professor Saltzburg's arguments accurately reflect the realities of the psychiatric examination process. ${ }^{373}$ If they were soundly based, they would support finding waiver of the attorney-chent privilege $\mathrm{m}$ the limited factual situation he describes. He presents a special and extreme form of the litigative fairness argument that would support a limited intrusion into the attorneyclient relationship. Professor Saltzburg's premise is that the defendant should not be able to imterject an issue imto the case and yet withhold the only direct evidence on that issue from the prosecution. This argument builds on the widely accepted justification for requiring the defendant to submit to a psychiatric examination by a state-chosen expert if he wishes to raise an msanity defense. While the precise articulations of the policy differ, they are all based on the concept of litigative fairness in its extreme form-necessity. ${ }^{374}$ If the underlying factual justification is both as compelling and as umiversally apphicable to insanity cases as Professor Saltzburg contends, then litigative fairness in this extreme form exists vis-a-vis discovery and use of the defendant's experts. The exception to

372. Saltzburg, supra note 345 , at $636-39$.

While these arguments have logical force, their validity ultimately rests upon empirical evidence Professor Saltzburg does not provide. He gives no evidence of how often his factual assumptions are valid or how they weigh against the values threatened by disclosing all unsuccessful examinations. Furthermore, he does not adequately explain why these arguments should eliminate the privilege for a whole class of experts, rather than provide a basis for voiding the privilege in individual cases where the facts support his arguments. While factual, case-by-case analysis will impose litigation costs and erroneously uphold the privilege in some instances due to lack of proof, there is no showing that such costs are prohibitive in the context of the important values threatened by broad application of a waiver doctrine.

373. Prior to Professor Saltzburg's formulation of a general rationale for waiver, courts occasionally examined some of these concerns specifieally. In those cases, when the state was required to demonstrate actual prejudice rather than rely on general presumptions, it failed to make the required showing. In Pouncy v. State, 353 So. 2d 640 (Fla. Dist. Ct. App. 1977), the state argued that waiver should be found because the defendant's experts conducted a more timely examination and therefore were "more qualified" than the state's experts and because protecting the testimony of the experts would permit the defendant to "scoop' up all qualified experts in a given field." The court recognized that possibility but found no support for it in the specific facts of the case. The defense called only two lay witnesses. The court held that the state's theoretical arguments did not justify its calling two defense experts in addition to its own two experts. Id. at 642 . By contrast in State v. Dodis, 314 N.W.2d 233 (Minn. 1982), the court upheld waiver of the privilege in a similar factual situation. The court accepted the broad policy arguments. The defendant offered only lay testimony, but the state was allowed to use not only a court appointed psychiatrist but also the one consulted by the defendant, $i d$. at 236 , prompting the observation that "[t]here is no showing on this record that a dearth of psychiatric evidence or witnesses available to the prosecution exists." Id. at 243 (Wahl, J., concurring).

374. See supra text accompanying notes 152-55, discussing United States v. Byers, 740 F.2d 1104 (D.C. Cir. 1984) (en banc). 
the attorney-client privilege, while potentially expansive, would be both justified and carefully constrained.

The facts of two recent federal cases dealing with discovery involve circumstances approaching necessity. Both circuit courts upheld waiver of the attorney-client privilege upon the defendants' raising the insanity defense. In Granviel v. Estelle ${ }^{375}$ and Noggle v. Marshall, ${ }^{376}$ the defendants refused to cooperate with any experts for the court or the prosecution, providimg especially strong justification for allowing the prosecution to use a dissenting defense expert. ${ }^{377}$ Because of their special facts, these cases are unlikely to be employed in a wholesale assault on the attorneyclient privilege.

In contrast, recent state court opinions have not analyzed this issue so carefully. Their broad sweep threatens to expand the argument in favor of disclosure from the logic of necessity to the general concept of hitigative fairness and beyond the specific context of the insamity defense to all expert investigation.

In State v. Craney, ${ }^{378}$ for example, the Iowa Supreme Court characterized the Alvarez decision as reflecting "the bygone philosophy that for an attorney's investigations to be effective they must be shrouded in secrecy." ${ }^{779}$ The opinion then emphasized that a party should not be able to put a " inatter imto issue and then deny access of the opposing party to relevant information concerning it." $" 380$ It concluded that the attorney-chent privilege is mapphicable because it would stultify "[f]ull disclosure of the facts." ${ }^{381}$ Conspicuously absent from the court's analysis is any careful limitation of waiver doctrime to the special circumstances of insamity defense hitigation. ${ }^{382}$

375. 655 F.2d 673, 683 (5th Cir. 1981), cert. denied, 455 U.S. 1007 (1983).

376. 706 F.2d 1408, 1411 (6th Cir.), cert. denied, 464 U.S. 1010 (1983).

377. Granviel, 655 F.2d at 683 ("We are especially driven to this outcome in this case where Granviel, at his counsel's urging, refused to cooperate with the experts who were appointed at the prosecution's request."); Noggle, 706 F.2d at 1411 (defendant examined by three defense experts appointed by court and retained by state).

378. 347 N.W.2d 668 (Iowa), cert. denied, 105 S. Ct. 255 (1984).

379. Id. at 677 .

380. Id. (quoting State v. Cole, 295 N.W. 2d 29, 35 (Iowa 1980)).

381. Id.

382. Similarly, in State v. Dodis, 314 N.W.2d 233, 239-40 (Minn. 1982), the Supreme Court of Minnesota observed without limitation to the insanity defense, "The United States Supreme Court has consistently held that reciprocal rules of discovery and testimony in a criminal setting have no constitutional infirmities." The court held that since the rule required the defense to turn over all reports and records relevant to the insanity defense and allowed the prosecution to use them, the state should be able to call any defense expert on the issue of insanity. It saw "little reason not to interpret the rules ... to give the defendant and prosecution as complete use of evidence as is possible under the constitutional limitations to enhance the search for truth." Id. at 240; see also People v. Sorna, 88 Mich. App. 351, 358, 276 N.W.2d 892, 895 (1979) (citations omitted):

Defendant stresses a variety of tactical disadvantages which may result if he is required to furnish the report of "any independent examiner" to the prosecution, including chilling of 
In State v. Carter, ${ }^{383}$ the Supreme Court of Missouri argued even more broadly that general principles of fairness provide adequate justification for prosecutorial discovery. ${ }^{384}$ It held the attorney-client privilege inapplicable on the theory that the defendant waived the privilege by pleading insanity. Turning to the propriety of ordering discovery under the rule, it noted first that the report was "[u]nquestionably . . . relevant and material to the State's case." 385 It then cited the state's duty to provide exculpatory reports to the defense and stated, "Just as the evidence would be available to the defendant in that case, so the evidence is available to the State in this. It is a poor rnle that does not work both ways."386

The court went on to emphasize both that the "fundamental pur" pose of a criminal trial is fair ascertainment of the truth" and that not only the defendant but also the state "has a direct interest in an accurate, just and inforined verdict based upon all available relevant and material evidence bearing on the question." 387 While recognizing that a defendant's interests im effective assistance of counsel may be soinewhat coinpromised, the court concluded that the state's discovery request was reasonable and its right to fairness outweighed the competing defense interest. ${ }^{388}$

It would be maccurate to read the langnage of these decisions as completely divorced from the special circumstances of the insanity defense in which they arose. ${ }^{389}$ Yet the broad langnage and analysis mvite just such an inaccurate reading. Courts have justified discovery

defendant-psychiatrist communication and discouragement of defense counsel exploration of the insanity issue by gathering a variety of medical opinions. This position ignores the fundamental purpose of a criminal trial: the fair ascertainment of the truth. A necessary concomitant of this goal is a reasonable balancing of advantages and a lessening of a vehemently adversary climate at trial.

383. 641 S.W.2d 54 (Mo. 1982) (en banc), cert. denied, 461 U.S. 932 (1983).

384. Missouri discovery rules permit trial judges, "[s]ubject to constitutional limitations," to require the defendant to furnish any relevent information when the court finds that the state's request is reasonable." MO. SuP. CT. R. CRIM. P. 25.06. In Carter, the trial court ordered discovery of a defense psychiatrist's report under Rule 25.06.

385. 641 S.W.2d at 58.

386. Id. In his dissent, Judge Seiler remarked on the inappropriateness of this argument: "Just because the defendant . . . is entitled to the report of the prosecutor's psychiatrist . . . does not mean the state is entitled to [the defense psychiatrist's] report or testimony here, because the state has no due process or Brady v. Maryland [373 U.S. 83 (1963)] constitutional right against the defendant." Id. at 66 (Seiler, J., dissenting).

387. Id. at 58 .

388. Id. at 59.

389. Indeed, in State ex rel. Richardson v. Randall, 660 S.W.2d 699 (Mo. 1983) (en banc), the Missouri Supreme Court distinguished Carter and found the state's request to discover the name of a defense handwriting expert unreasonable under the same rule, Mo. SuP. CT. R. CRIM. P. 25.06(A), when the defense did not intend to call the expert. It tied the result in Carter to the insanity defense and limited the use of a defendant's expert to the situation where evidence concerning insanity is presented at trial. 660 S.W.2d at 701-02. 
with a general argument of hitigative fairness and the state's interest in accurate resolution of the issues. On this basis, they have required the production of all relevant evidence. If the defendant presents nothing at trial to which his communications may be relevant, then it is indeed unlikely that discovery and use by the state will be permitted.

The stage is now set, however, for an expansion of the "fairness" doctrine. The next incursion likely will be outside the insanity area, when the defendant presents evidence to which his confidential communications may provide relevant rebuttal. Indeed, the Supreme Court of New Mexico, a state that authorizes very broad prosecutorial discovery, took that critical next step and though the court subsequently overruled the result by changing the rule, it did not disavow its earlier analysis. ${ }^{390}$ In State v. Harrison, ${ }^{391}$ the court permitted the state to impeach the defendant with his confidential communications to a defense polygrapli examiner. The defendant objected under the work product doctrine and the attorney-chent privilege. The court brushed aside botli those arguinents, citing only Harris v. New York. ${ }^{392}$ In its broad holding, the court pronounced that both the defendant's statements to the polygraph operator and the results of the exammation "may be used to impeach a defendant who takes the stand." $" 393$

Again, one cannot be certain of how far these developments will proceed. ${ }^{394}$ Unfortunately, however, this progression, from authorizing state use of protected communications in an area of special need, to autliorizing use of such communications to impeach the defendant's testimony if he takes the stand, has a familiar ring. It is mucli like the well documented movement from approval of impeachment witl illegally

390. See Tofoya v. Baca, 103 N.M. 56, 702 P.2d 1001 (1985).

391. 90 N.M. 439, 564 P.2d 1321 (1977). See supra note 344.

392. 401 U.S. 222 (1971).

393. Harrison, 90 N.M. at 443,564 P.2d at 1325.

394. Cf. State v. Holland, 98 Wash. 2d 507, 656 P.2d 1056 (1983) (en banc). In Holland, the Supreme Court of Washington accepted the proposition that the fifth amendment applies to courtappointed mental health professionals but held that they could be called to impeach the defendant. The court found no evidence that the defendant's statements to the experts had been coerced. It rested its holding on Harris v. New York, 401 U.S. 222 (1971).

Other courts have found the defendant's statements to agents of his attorney protected by the attorney-client privilege. State v. Melvins, 155 N.J. Super. 316, 382 A.2d 925 (1978) (order requiring defendant to provide results of his polygraph test which counsel did not intend to use at trial violated attorney-client privilege and his right to effective assistance of counsel); People v. Knippenberg, 66 Ill. 2d 276, 362 N.E.2d 681 (1977) (impeachment of defendant with report by his counsel's investigator violates both attorney-client privilege and effective assistance of counsel); People v. Marcy, 91 Mich. App. 399, 283 N.W.2d 754 (1979) (attorney-clieut privilege bars state from calling defense polygraph examiner to testify at grand jury concerning statements by suspect concerning murder of his wife). Except in Knippenberg, however, no court addressed whether such statements might be used to impeach. 
obtained evidence, ${ }^{395}$ first authorized under similar circumstances of special justification in Agnello v. United States ${ }^{396}$ and Walder v. United States, ${ }^{397}$ to almost coinpletely unconstrained authority for the prosecution to use such evidence under Harris v. New York ${ }^{398}$ and United States v. Havens. ${ }^{399}$

Perhaps the attorney-chent privilege and the underlying concern for the sixth ainendment right to effective assistance of counsel will prove a stronger restraint on the use of these communications to impeach, but this is far from certain should hitigative fairness become the focus of concern. If waiver of the attorney-client privilege turns on general fairness, waiver may be predicated on any inconsistent testimony by the defendant. Sixth amendment protections might be similarly waived when the defendant testifies. ${ }^{400}$

One of two possibilities will follow. Either courts will rule that waiver occurs only upon a showing of necessity-that the privilege can only be breached by a state interest in preventing the defendant from using it to obtain a further advantage where he has a virtual monopoly on relevant evidence- or a defendant will be able to communicate with his attorney and agents in true confidence only if he is willing to forego the right to take the stand. I contend that the state's interests in a fair resolution of the issues and the search for the truth does not justify a state right to secure rebuttal evidence any time the defendant takes the stand or introduces evidence. The adoption of such a principle would alter our adversarial criminal system in a truly fundamental way. Courts must recognize that basic principles that undergird our adversarial system were designed to prevent discovery of confidential cominunications between the defendant and his counsel or counsel's agents, even at the cost of sacrificing optimal factfinding.

\section{CONCLUSION}

Since the Williams decision, courts and legislatures applying concepts of litigative fairness and efficiency to criminal discovery have greatly dimimished protections for defense secrets and confidences. In

395. See 1 W. LaFave \& J. Israel, Criminal Procedure $\$ 9.6$ (1984); 3 W. LaFave, SEARCH AND SEIZURE § 11.6 (1978 \& Supp. 1985); see also Bradley, supra note 124, at 423-30.

396. 269 U.S. 20 (1925).

397. 347 U.S. 62 (1954).

398. 401 U.S. $222(1971)$.

399. 446 U.S. $620(1980)$.

400. Perhaps the line will be drawn between statements directly to the attorney, which will be protected, and those to his agents when the agent is performing an arguably nonlegal service and the central issue in the litigation is within his expertise, which will not be protected. If necessity rather than general litigative fairness is the standard, it is hard to imagine that the sixth amendment right to effective assistance of counsel would not be violated by allowing the use of statements made directly to counsel for legal advice, at least where perjury by the defendant is not involved. 
doing this, they have largely ignored fifth and sixth amendment restramts, principally because of inadequate or superficial analysis. At the saine time, the attorney-chent privilege and the work product doctrine have been reduced from positions of special importance in defining the basic contours of the adversary system to virtually nothing more than factors to be balanced in the process of reaching an efficient and equitable result. Nevertheless, the basic guarantees of the fifth and sixth amendments, as well as the pohicies underlymg the work product doctrine and the attorney-chent privilege, remain mconsistent with major elements of discovery against the defense.

Such developments in criminal discovery have gone far beyond articulation of new doctrine; the practical consequences have been nothing short of revolutionary. More than half of the states have accepted the Court's invitation in Wardius to experiment "with systems of broad discovery." They have expanded criminal discovery generally and im the process have extended discovery agaimst the defense, often perimitting very extensive prosecutorial discovery. The result has been to change fundamentally the criminal hitigation system, to shift the balance of advantage im favor of the prosecution, and to violate the Constitution. With the results clear, it is now time to bring this experiment under control and to restore the balance mandated by basic constitutional and evidentiary principles. 
